\title{
Performance Evaluation of a \\ Selected Three-Ton Air-to-Air Heat Pump in the Heating Mode
} UNION CARBIDE

A. A. Domingorena

S. J. Ball

ENVIRONMENTAL SCIENCES DIVISION

Publication No. 1367

OPERATED BY

UNION CARBIDE CORPORATION FOR THE UNITED STATES DEPARTMENT OF ENERGY 


\section{DISCLAIMER}

This report was prepared as an account of work sponsored by an agency of the United States Government. Neither the United States Government nor any agency Thereof, nor any of their employees, makes any warranty, express or implied, or assumes any legal liability or responsibility for the accuracy, completeness, or usefulness of any information, apparatus, product, or process disclosed, or represents that its use would not infringe privately owned rights. Reference herein to any specific commercial product, process, or service by trade name, trademark, manufacturer, or otherwise does not necessarily constitute or imply its endorsement, recommendation, or favoring by the United States Government or any agency thereof. The views and opinions of authors expressed herein do not necessarily state or reflect those of the United States Government or any agency thereof. 


\section{DISCLAIMER}

Portions of this document may be illegible in electronic image products. Images are produced from the best available original document. 


\section{Printed in the United States of America. Available from National Technical Information Service \\ U.S. Department of Commerce \\ 5285 Port Royal Road, Springfield, Virginia 22161 \\ NTIS price codes-Printed Copy: A06 Microfiche A01}

This report was prepared as an account of work sponsored by an agency of the United States Government. Neither the United States nor any agency thereof, nor any of their employees, makes any warranty, expressed or implied, or assumes any legal liability or responsibility for any third party's use or the results of such use of any information, apparatus, product or process disclosed in this report, or represents that its use by such third party would not infringe privately owned rights. 
PERFORMANCE EVALUATION OF A SELECTED THREE-TON AIR-TO-AIR HEAT PUMP IN THE HEATING MODE

\title{
by
}

\author{
A. A. Domingorena* \\ Energy Division \\ S. J. Ball \\ Instrumentation and Controls Division \\ DEPARTMENT OF ENERGY \\ Division of Buildings and Community Systems
}

Date Published: Januäry 1980

OAK RIDGE NATIONAL LABORATORY

Oak Ridge, Tennessee 37830

operated by

UNION CARBIDE CORPORATION

for the

DEPARTMENT OF ENERGY

\footnotetext{
Now with Carrier Corporation, BIdg. TR-4, Box 4803, Carrier Parkway, Syracuse, NY 13221.
} 
THIS PAGE

\section{WAS INTENTIONALLY LEFT BLANK}


PREVIOUSLY PUBLISHED REPORTS IN THIS SERIES

A. A. Domingorena, Performance Evaluation of a Low-First-Cost, Three-Ton, Air-to-Air Heat Pump in the Heating Mode, ORNL/CON-18 (October 1978). 


\section{THIS PAGE}

\section{WAS INTENTIONALLY LEFT BLANK}


TABLE OF CONTENTS

Page

LIST OF FIGURES . . . . . . . . . . . . . . . . . . . vii

LIST OF TABLES . . . . . . . . . . . . . . . . . . . . . . . $\quad$.

ABSTRACT . . . . . . . . . . . . . . . . . 1

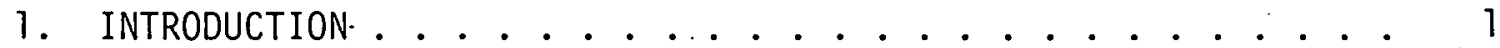

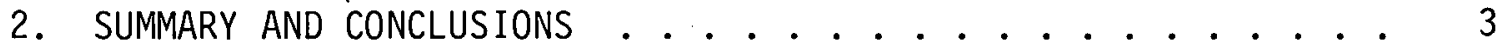

2.1 Heating Capacity and Coefficient of Performance

under Steady-State (Nonfrosting) Conditions ....... . 3

2.2 Fan and Fan-Motor Efficiencies . . . . . . . . . . . 3

2.3 Heat Exchanger and Orifice-Type Refrigerant

Metering Device Performance .............. 4

2.4 Heat Losses....................... . . . . . . 5

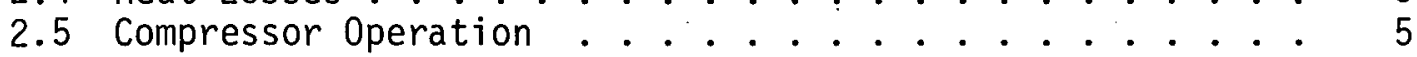

2.6 Performance Under Frosting Conditions . . . . . . . . 5

2.7 Effect of Component Inefficiencies . . . . . . . . . ... 7

2.8 Effect of Refrigerant Charge ............. . 7

3. DESCRIPTION OF TEST UNIT . . . . . . . . . . . . . . . 11

4. DESCRIPTION OF TEST APPARATUS : . . . . . . . . . . . . . 13

4.1 Test Loops . . ... . . . . . . . . . . . . . . . . 13

4.2 Instrumentation ................ 74

4.2.1 Temperature ................. 14

4.2.2 Pressure .................. 18

4.2.3 Refrigerant flow rate ........... 18

4.2.4 Airflow rate................ 18

4.2.5. Electrical power input........... 19

4.2.6 Humidity................... . 19

4.3 DAS and Program ..................... 19

5. TEST PROCEDURE .............................. 21

5.1 Steady-State Tests . . . . . . . . . . . . . 21

5.2 Frosting-Defrosting Tests.............. 21

5.3 Fan Tests.. . . . . . . . . . . . . . . . . 22

5.4 Refrigerant Charge Tests . . . . . . . . . . . 22

6. STEADY-STATE TEST RESULTS ................ . . . 23

6.1 Heating Capacity and COP .............. . . 23

6.2 Fan Performance . . . . . . . . . . . . . 26

6.2.1 Indoor-unit fan ............... 26

6.2.2 Outdoor-unit fan............. 29 
6.3 Heat Exchanger and Refrigerant Metering Device

Performance ............... 29

6.3.1 Condenser (indoor coil) ........... 31

6.3.2 Evaporator (outdoor coi1) . . . . . . . . . 31

6.4 System Heat Losses . . . . . . . . . . . . . 36

6.5 Compressor Operation ................. 37

7. FROSTING-DEFROSTING TESTS .................... 41

7.1 System Performance Under Frosting Conditions . . . . . 41

7.1 .1 Test at $0.6^{\circ} \mathrm{C}\left(33^{\circ} \mathrm{F}\right)$ and $100 \%$ relative humidity ................... 41

7.1.2 Tests at $0.6^{\circ} \mathrm{C}\left(33^{\circ} \mathrm{F}\right)$ and 92 to $97 \%$ relative humidity .............. 42

7.1.3 Tests at $-2.2^{\circ} \mathrm{C}\left(28^{\circ} \mathrm{F}\right)$ and 80 to $85 \%$ relative humidity ..................... 42

7.1.4 Defrost water collection .......... . . 55

7.2 Compressor. Performance During the Defrosting

Period ........................... 55

8. REFRIGERANT CHARGE VARIATION TESTS ........... 61

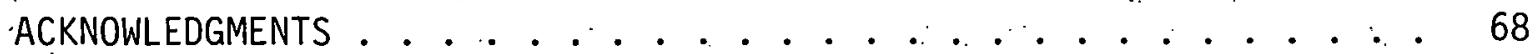

REFERENCES . . . . . . . . . . . . . . . . 69

Appendix A - Experimental Data ............. . . 73

Appendix B - Fan-Motor Efficiency Evaluation . . . . . . . 79

Appendix C - Algorithms for Calculating Thermodynamic Properties of Refrigerant 22 ............ . . 83

Appendix D - Computer Program for the Data Acquisition System . . 85 


\section{LIST OF FIGURES}

Figure

Page

2.1 Effect of component inefficiencies on system efficiency under steady-state, nonfrosting conditions . . . . . 8

4.1 Schematic diagram of test loop for the indoor unit . . . 15

4.2 Schematic diagram of test loop for the outdoor unit . . . 15

4.3. Experimental apparatus . . . . . . . . . . 16

4.4 Schematic diagram of refrigerant circuit for the heat pump in the heating mode ............. . 17

4.5 DAS temperature measurement scheme . . . . . . . . . 17

6.1 System heating capacity as a function of outdoor air temperature................... 24

6.2 System coefficient of performance as a function of outdoor air temperature............... . 25

6.3 Power input as a function of outdoor air temperature . . . 27

6.4 Indoor fan characteristics . . . . . . . . . . 28

6.5 Outdoor fan characteristics............. 30

6.6 Schematic diagram of the refrigerant circuits in the indoor coil..................... . . 33

6.7 Temperature profiles for one refrigerant circuit of the indoor coil. The outdoor air temperature was $1.0^{\circ} \mathrm{C}\left(33.8^{\circ} \mathrm{F}\right)$ for run $1,13.3^{\circ} \mathrm{C}\left(56.0^{\circ} \mathrm{F}\right)$ for run $2,18.6^{\circ} \mathrm{C}\left(65.4^{\circ} \mathrm{F}\right)$ for run 3 , and $5.7^{\circ} \mathrm{C}\left(42.3^{\circ} \mathrm{F}\right)$ for run $4 . . . . . . . .334$

7.1 Heating capacity and COP during a 50 min frosting period with outdoor air at $0.6^{\circ} \mathrm{C}$. and $100 \%$ relative humidity . . 43

7.2. Outdoor-coil air pressure drop and airflow rate during 50 min frosting period with outdoor air at $0.6^{\circ} \mathrm{C}$ and $100 \%$ relative humidity ................ . 44

7.3 Refrigerant pressures and flow rates during a 50 min frosting period with outdoor air at $0.6^{\circ} \mathrm{C}$ and $100 \%$ relative humidity . . . . . . . . . . . . . 4 4 
Figure

Page

7.4 Compressor and outdoor-fan power consumption during a 50 min frosting period with outdoor air at $0.6^{\circ} \mathrm{C}$ and $100 \%$ relative humidity . . . . . . . . . . . . .

7.5 Heating capacity and COP during a 90 min frosting period with outdoor air at $0.6^{\circ} \mathrm{C}$ and $92-97 \%$ relative humidity. . . . . . . . . . . .........

7.6 Outdoor-coil air pressure drop and airflow rate during a 90 min frosting period with outdoor air at $0.6^{\circ} \mathrm{C}$ and $92-97 \%$ relative humidity ... . . . . . . . . .

7.7 . Refrigerant pressures and flow rates during a $90 \mathrm{~min}$ frosting period with outdoor air at $0.6^{\circ} \mathrm{C}$ and $92-97 \%$ relative humidity . . . . . . . . ........

7.8 Compressor and outdoor fan power consumption during a 90 min frosting period with outdoor air at $0.6^{\circ} \mathrm{C}$ and $92-97 \%$ relative humidity . . . . . . . . . . . .

7.9 Heating capacity and COP during a 90 min frosting period with outdoor air at $-2.2^{\circ} \mathrm{C}$ and $80-85 \%$ relative humidity

7.10 Outdoor-coil air pressure drop and airflow rate during a 90 min frosting period with outdoor air at $-2.2^{\circ} \mathrm{C}$ and $80-85 \%$ relative humidity . . . . . . . . . . . . .

7.11 Refrigerant pressures and flow rates during a 90 min frosting period with outdoor air at $-2.2{ }^{\circ} \mathrm{C}$ and $80-85 \%$ relative humidity . . . . . . . . ... . . . . .

7.12 Compressor and outdoor fan power consumption during a 90 min frosting period with outdoor air at $-2.2^{\circ} \mathrm{C}$ and $80-85 \%$ relative humidity . . . . . . . . . . .

7.13 Power consumption and system pressures during a defrosting period following a 50 min frosting interval with the outdoor air at $0.6{ }^{\circ} \mathrm{C}$ and $100 \%$ relative humidity .......

7.14 Power consumption and system pressures during a defrosting period following a 90 min frosting interval with the outdoor air at $0.6^{\circ} \mathrm{C}$ and $92-97 \%$ relative humidity . ...

7.15 Power consumption and system pressures during a defrosting period following a 90 min frosting interval with the outdoor air at $-2.2^{\circ} \mathrm{C}$. and $80-85 \%$ relative humidity 
ix

Figure

Page

8.1 Suction gas superheat as a function of refrigerant charge.................... 62

8.2 System pressures as a function of refrigerant charge . . 63

8.3 Mass flow rate of refrigerant as a function of refrigerant charge ................ 64

8.4 Heating capacity as a function of refrigerant charge . . 66

8.5 Coefficient of performance as a function of refrigerant charge. The COP of the low-first-cost unit, which lacks a suction line accumulator, is shown for comparison . . . 67 
THIS PAGE

\section{WAS INTENTIONALLY LEFT BLANK}


Table

$\underline{\text { Page }}$

2.1 Observed vs rated performance of the heat pump at $8^{\circ} \mathrm{C}$ outdoor air temperature and $21^{\circ} \mathrm{C}$ indoor air temperature

2.2 Measured values of combined efficiency of the indoor and outdoor fan and fan-motor units . . . . . . . . . . 4

2.3 Conditions for frosting tests . . . . . . . . . . . 6

2.4 Heat pump conditions at conclusion of the frosting periods ..................... 6

3.1 Principal features of test unit . . . . . . . . . . 12

6.1 Steady-state indoor cojl (condenser) performance . . . . . 32

6.2. Steady-state outdoor coil (evaporator) performance . . . . 35

6.3 System heat loss rates . . . . . . . . . . . . . 36

6.4 Compressor operating characteristics . . . . . . . . . . 38

7.1 Frost accumulation as evaluated by defrost water drain collection ..................... 55

A. 1 Test data from steady-state runs . . . . . . . . . . . 75

A.2 Test data for frosting/defrosting tests . . . . . . . 76

A.3 Test data for charge variation tests . . . . . . . . 77

B. 1. Indoor-fan test data : . . . . . . . . . . . . . . . 79

B.2 Overall efficiency of the indoor fan-motor unit as
a function of airflow rate................. 80

B.3 Outdoor-fan test data . . . . . . . . . . . . . 81 B.4. Overali efficiency of the outdoor fan-motor unit as a.
function of airflow rate . . . . . . . . . . . . . . 81 
PERFORMANCE EVALUATION OF A SELECTED THREE-TON.

AIR-TO-AIR HEAT PUMP IN THE HEATING MODE

- A. A. Domingorena

Energy Division

S. J. Ball

Instrumentation and Controls Division

\begin{abstract}
An air-to-air split systeil residential heat pump of nominal three-ton capacity was instrumented and tested in the heating mode under laboratory conditions. This was the second of a planned series of experiments to obtain a data base of system and component performance for heat pumps. The system was evaluated under both steady-state and frosting-defrosting conditions; sensitivity of the system performance to variations in the refrigerant charge was measured.

From the steady-state tests, the heating capacity and coefficient of performance were computed, and evaluations were made of the performance parameters of the fan and fan motor units, the heat exchangers and refrigerant metering device, and the compressor. System heat losses were analyzed. The frostingdefrosting tests allowed the observation of system and component performance under dynamic conditions, and measurement of performance degradation under frosting conditions.
\end{abstract}

\title{
1. INTRODUCTION
}

This report describes the procedures and results of the second of a planned series of experiments that will establish a data base of the performance characteristics of commercially available heat pumps. The experiments are being conducted as part of a heat pump research program by the Oak Ridge National Laboratory for the Department of Energy, Office of Conservation and Solar Applications, Division of Buildings and Community Systems. The overall objective of this program is to identify and promote cost-effective modifications in heat pump design that can substantially reduce energy consumption in residential and commercial buildings. This objective is being approached in a combined experimental 
and theoretical study. A data base on heat pump system and component performance is being obtained experimentally and computer models are being formulated to evaluate various candidate improvements analytically.

In order to provide the level of detail required for these analyses, the experiments are much more extensive than those that would be required for comparing heat pump ratings. The emphasis is on gathering information for design studies rather than providing consumer information.

The specific objectives of the experiments described herein are:

1. to determine the base-case performance of the selected heat pump and the characteristics of some of its components under both steady-state and frosting/defrosting conditions;

2. to measure experimentally the degradation of heat pump performance due to frost formation on the outdoor coili and

3. to measure the sensitivity of the performance parameters to variations in the refrigerant charge.

Previous tests ${ }^{1}$, were of a low-first-cost heat pump typical of those that might be selected by a speculative home builder. For the experiments reported herein, the tests were conducted on a "middle-of-the-line" nominal three-ton, air-to-air split system heat pump consisting of an indoor and an outdoor unit separated by $7.6 \mathrm{~m}(25 \mathrm{ft})$ of liquid-1ine and vapor-1ine refrigerant tubing. The test facility consisted of two "bootstrap" air duct loops which are described in this report. As in the previous tests, efforts were concentrated on the performance of the heat pump in the heating mode of operation. Performance improvements in this mode present the greater opportunity for enhancing the energy conserving potential of heat pumps. 


\section{SUMMARY AND CONCLUSIONS}

\subsection{Heating Capacity and Coefficient of Performance under Steady-State (Nonfrosting) Conditions}

The observed capacity of the system under steady-state nonfrosting conditions compared reasonably well with rated values published by the Air Conditioning and Refrigeration Institute (ARI). ARI rating conditions for this test are: $1150 \mathrm{cfm}$ of air at $70^{\circ} \mathrm{F}(\mathrm{db})$ at the indoor unit, $47^{\circ} \mathrm{F}(\mathrm{db})$ air at $43^{\circ} \mathrm{F}(\mathrm{wb})$ supplied to the outdoor unit. The observed values (Table 2.1) are from tests with $1200 \mathrm{cfm}$ of air at $69.8^{\circ} \mathrm{F}$ supplied to the indoor unit, $47^{\circ} \mathrm{F}(\mathrm{db})$ air to the outdoor unit. No condensation of air moisture was observed on the outdoor coil. The heating capacity and COP were measured by two methods, aị-side heat balance and refrigerant-side heat balance, which yielded reasonably close results. As shown in Table 2.1 , the COP observed by the air-side measurements was $7 \%$ lower than the rated value; that observed by the refrigerant-side measurements was $14 \%$ lower than rated.

Table 2.1. Observed vs rated performance of the heat pump at $8^{\circ} \mathrm{C}$ outdoor air temperature and $21^{\circ} \mathrm{C}$ indoor air temperature

\begin{tabular}{lllll}
\hline & $\begin{array}{l}\text { Rated } \\
\text { value }\end{array}$ & \multicolumn{2}{c}{ Abserved value } \\
\hline Heating capacity, & kW & 9.96 & Refrigerant \\
COP & 2.5 & 2.96 & 9.37 \\
Power input, kW & 4.05 & \multicolumn{2}{c}{4.35} \\
\hline
\end{tabular}

\subsection{Fan and Fan-Motor Efficiencies}

The measured combined efficiency of the indoor fan and fan-motor (defined as the ratio of the power used in moving the air to the electrical power to the fan-motor), was quite low, varying between 0.17 and 0.25 (Table 2.2). 
Table 2.2. Measured values of combined efficiency of the indoor and outdoor fan and fan-motor units

\begin{tabular}{|c|c|c|c|c|}
\hline & \multirow{2}{*}{$\begin{array}{l}\text { Motor speed } \\
\text { (RPM) }\end{array}$} & \multicolumn{2}{|c|}{ Airflow } & \multirow{2}{*}{$\begin{array}{l}\text { Combined } \\
\text { efficiency }\end{array}$} \\
\hline & & $\left(m^{3} / s\right)$ & $\left(f t^{3} / \min \right)$ & \\
\hline & 850 & 0.54 & 1150 & 0.17 \\
\hline . & 850 & 0.35 & 750 & 0.25 \\
\hline Indoor unit & 950 & 0.54 & 1150 & 0.22 \\
\hline$\therefore \therefore$ & $\cdot 950$ & 0.50 & 1050 & 0.22 \\
\hline \multirow{2}{*}{ Outdoor unit } & N.A. & 1.32 & 2800 & 0.11 \\
\hline & N.A. & 1.04 & 2200 & 0.14 \\
\hline
\end{tabular}

For the outdoor fan and fan-motor unit, the combined efficiency was even lower, from 0.11 to 0.14 (Table 2.2). As in the case of the lowfirst-cost unit, it is concluded that the fan and fan-motor units are not operating at their best efficiency. The opportunity for improvement in the combined fan and fan-motor efficiencies is apparent.

\subsection{Heat Exchanger and Orifice-Type Refrigerant Metering Device Performance}

Heat exchanger performance is closely related to the flow characteristics of the refrigerant metering device. The restriction of the metering device establishes a condensing pressure such that the difference between the condensing temperature in the indoor coil and that of the indoor air entering the condenser is 17 to $31^{\circ} \mathrm{C}\left(30.6\right.$ to $56^{\circ} \mathrm{F}$ ) for outdoor air temperatures ranging from -5 to $13^{\circ} \mathrm{C}\left(23\right.$ to $\left.55^{\circ} \mathrm{F}\right)$. For this coil, the difference between the refrigerant exit temperature and the entering a ir temperature varies from 14.2 to $15.4^{\circ} \mathrm{C}\left(25.5\right.$ to $\left.27^{\circ} .7^{\circ} \mathrm{F}\right)$. Measurement of refrigerant temperatures in this coil shows a marked variation in the amount of liquid refrigerant in the coil for different values of the ambient air entering the outdoor coil.

For the range of test values of outdoor air temperatures of -4.4 to $13.9^{\circ} \mathrm{C}\left(24\right.$ to $\left.57^{\circ} \mathrm{F}\right)$, the refrigerant pressures at the evaporator exit allow the presence of liquid refrigerant in the suction-line accumulator; 
superheat of the refrigerant delivered to the compressor shell is thus held to the range of 0 to $2.2 \mathrm{C}^{\circ}\left(0\right.$ to $\left.4 \mathrm{~F}^{\circ}\right)$. For the outdoor coil (evaporator), the difference between refrigerant exit temperature and entering air temperature varies from 5.9 to $10.8^{\circ} \mathrm{C}\left(10.6\right.$ to $\left.19.4^{\circ} \mathrm{F}\right)$, falling within the expected range of values.

\subsection{Heat Losses}

About 0.9 to $1.2 \mathrm{~kW}(3100$ to $4100 \mathrm{Btu} / \mathrm{hr}$ ) are rejected as heat from the hermetically sealed shell containing the compressor and motor when the outdoor air temperature is in the range -5 to $13^{\circ} \mathrm{C}\left(23\right.$ to $\left.55^{\circ} \mathrm{F}\right)$. This loss, 28 to $30 \%^{\circ}$ of the compressor-motor power input, helps cool the compressor but reduces the efficiency of the heat pump system in the heating mode. Heat losses from the discharge line vary from $0.41 \mathrm{~kW}$ $(1400 \mathrm{Btu} / \mathrm{hr})$ to $0.54 \mathrm{~kW}(1800 \mathrm{Btu} / \mathrm{hr})$ for the same outdoor temperature range.

\subsection{Compressor Operation}

The combined compressor and compressor-motor efficiency, defined as the ratio of ideal (isentropic) work (based on refrigerant conditions at shell inlet and outlet) to measured electrical energy input, varied from about 0.41 at $13.9^{\circ} \mathrm{C}\left(57^{\circ} \mathrm{F}\right)$ outdoor air to about 0.52 at $-4.4^{\circ} \mathrm{C}$ $\left(24^{\circ} \mathrm{F}\right)$.

\subsection{Performance under Frosting Conditions}

Tests of the heat pump under three different conditions favoring frost formation on the outdoor coil were conducted at the outdoor air temperatures and humidities shown in. Table 2.3. The test under the most severe frosting conditions was terminated after 50 min, by which time the airflow through the outdoor coil had decreased substantially, with concurrent rapid decrease in system high- and low-side refrigerant pressures. Performance summaries. for the system at the conclusion of the frosting tests are shown in Table 2.4. The amount of frost formed 
Table 2.3. Conditions for frosting tests

\begin{tabular}{cccc}
\hline Condition No. & $\begin{array}{c}\text { Relative humidity } \\
(\%)\end{array}$ & $\begin{array}{c}\text { Outdoor air } \\
\text { dry bulb } \\
\text { temperature } \\
{\left[{ }^{\circ} \mathrm{C}\left({ }^{\circ} \mathrm{F}\right)\right]}\end{array}$ & $\begin{array}{c}\text { Approximate } \\
\text { frosting. } \\
\text { interval } \\
\text { (min) }\end{array}$ \\
\hline 1 & 100 & $0.6-4.4(33-40)$ & 50 \\
2 & $92-97$ & $0.6-4.4(33-40)$ & 90 \\
3 & $80-85$ & $-2.2^{\circ}(28)$ & 90 \\
\hline
\end{tabular}

Tabie 2.4. Heat pump conditions at conclusion of the frosting periods.

\begin{tabular}{lccc}
\hline & \multicolumn{3}{c}{ Condition } \\
\cline { 2 - 4 } & 1 & 2 & 3 \\
\hline $\begin{array}{c}\text { Outdoor-coil airflow, } \mathrm{m}^{3} / \mathrm{s} \\
\text { (cfm) }\end{array}$ & $0.24(510)$ & $0.26(550)$ & $1.47 \cdot(3115)$ \\
$\begin{array}{c}\text { Outdoor-coil air pressure } \\
\text { drop, } \mathrm{kPa}(\mathrm{in} . \mathrm{H} 0)\end{array}$ & $0.13(0.52)$ & $0.14(0.56)$ & $0.04(0.16)$ \\
$\begin{array}{c}\text { Outdoor fan-motor power, } \\
\text { kW }\end{array}$ & 0.49 & 0.45 & 0.42 \\
$\begin{array}{l}\text { Heating capacity, kW. } \\
\text { (Btu/hr) }\end{array}$ & $6.56(22400)$ & $6.42(21900)$ & $6.74(23000)$ \\
Cop & 1.75 & 1.74 & 1.78 \\
\hline
\end{tabular}

on the coil was estimated by collecting the water drained from the coil during the subsequent defrost periods. The defrost water thus collected ranged from 1.1 liters ( 0.29 gallons) during the first defrosting period to 1.3 liters ( 0.34 gallons) for the second period when the system was operated with the outdoor air at $0: 6^{\circ} \mathrm{C}\left(33^{\circ} \mathrm{F}\right)$ and at $100 \%$ relative humidity (condition 1). The COP values shown are those measured at the end of the frosting periods, just before the defrost cycle is initiated. Graphs of the transient refrigerant pressures during the defrost cycles show that for condition 1 the high-side refrigerant pressure decreased to its lowest value after about 0.5 min of defrosting while the low-side (suction) pressure reached its lowest point after 1 min 
of defrosting operation. These pressure variations may be explained by the condensation and subsequent accumulation of refrigerant in the cold outside coil. After about 1 min of defrosting, the pressures start to rise as heat is transferred to the frosted outside coil at a substantial rate.

\subsection{Effect of Component Inefficiencies}

An ideal vapor-compression cycle using R-22 as the working fluid would have a COP of 21.45 when it is operating between the temperature limits of 21 and $8^{\circ} \mathrm{C}\left(70\right.$ and $\left.47^{\circ} \mathrm{F}\right)$. Temperature differences across the heat exchangers, a necessary condition for operation of a real system, reduce the computed COP substantialiy. Heat exchanger temperatures observed during the steady-state tests at $8^{\circ} \mathrm{C}$ outdoor air temperature were:

$50^{\circ} \mathrm{C}\left(122^{\circ} \mathrm{F}\right)$ condensing $\quad-1.2^{\circ} \mathrm{C}\left(29.8^{\circ} \mathrm{F}\right)$ evaporating

$14.6 \mathrm{C}^{\circ}\left(26.2 \mathrm{~F}^{\circ}\right)$ subcooling $O \mathrm{C}^{\circ}\left(0 \mathrm{~F}^{\circ}\right)$ superheat

The computed COP using these temperature differences in an otherwise ideal system is 5.6 , a $74 \%$ reduction from the idea 7 , reversible cycle COP.

The observed component inefficiencies and heat losses reduce the calculated COP further, as shown in Fig. 2.1. A combined compressor and motor efficiency of 0.47 reduces the COP to 3.2, an additional $43 \%$ loss. The substantial heat losses observed at the compressor shell reduce the COP an additional $16 \%$ to 2.7 . Ideal fan power consumption would reduce the COP to 2.6; the observed fan and fan-motor inefficiencies reduce the COP an additional 15\% to the value of 2.2 , which is about the observed value for the heat pump operating in steady state at these conditions.

\subsection{Effect of Refrigerant Charge}

The experimental results indicate that the performance of this heat pumin in the heating mode is insensitive to increases of the refrigerant 


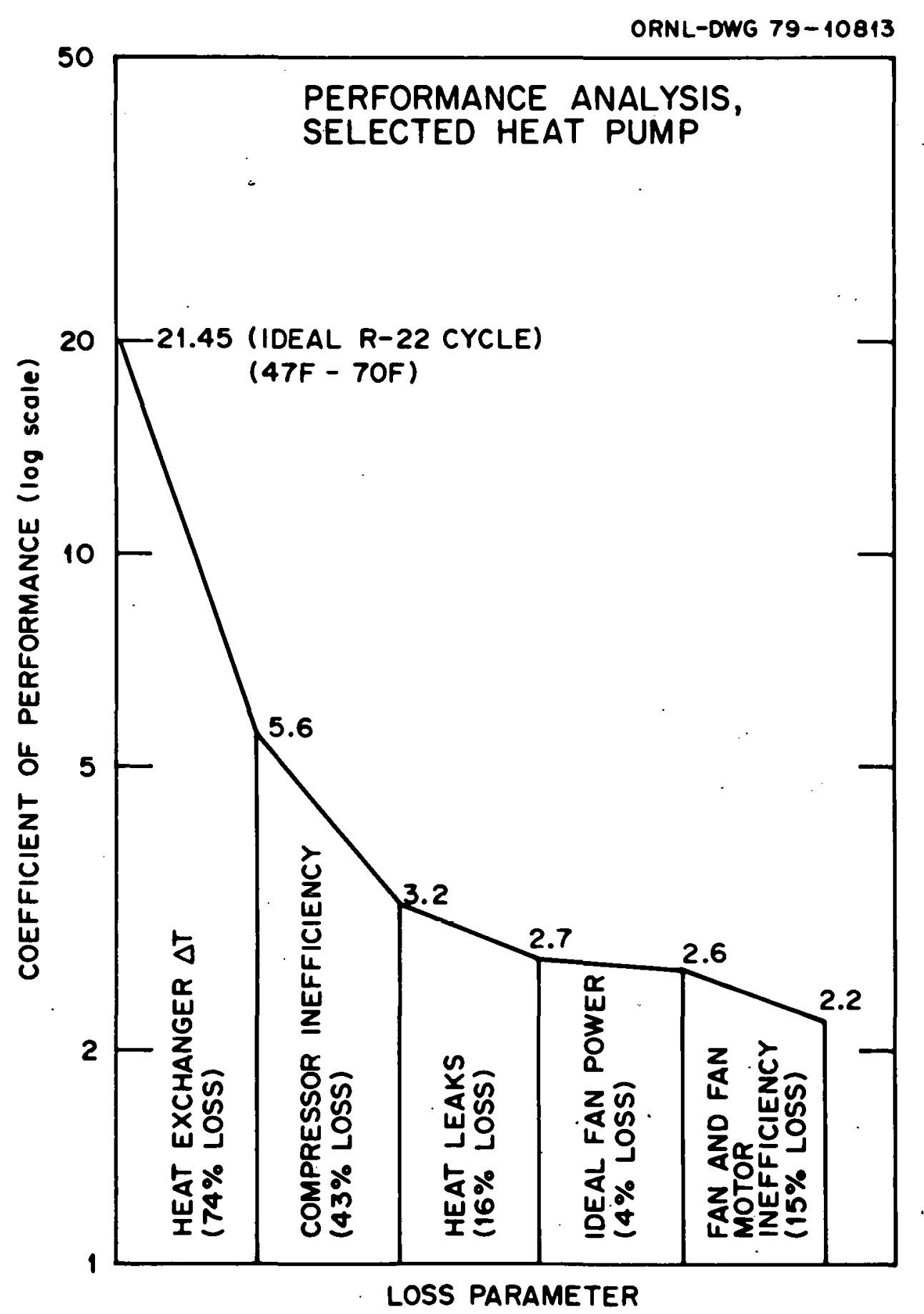

Fig. 2.1. Effect of component inefficiencies on system efficiency under steady-state, nonfrosting conditions. 
charge by as much as $25 \%$ above the nominal value of $2.86 \mathrm{~kg}(6 \mathrm{lb}, 5 \mathrm{oz})$, and is essentially insensitive to a charge reduction of $15 \%$ below the rated amount. This insensitivity is in contrast to the behavior of the low-firstcost unit previously tested, ${ }^{1}$ which has no suction-line accumulator and showed an almost linear reduction of heating capacity and COP with reduction of refrigerant charge. 
THIS PAGE

\section{WAS INTENTIONALLY LEFT BLANK}




\section{DESCRIPTION OF TEST UNIT}

The heat pump evaluated in this study is a commercially available unit designated as an air-to-air split system, with a nominal capacity of three tons. The salient characteristics of this unit are presented in Table 3.1.

The defrosting control operates on a time-and-temperature principle. In order for the heat pump to enter the defrosting mode of operation, two sets of contacts must be closed: those on the defrost timer, and those on the defrost thermostat. The defrost thermostat is set to close its contacts at $-0.6 \pm 2.2^{\circ} \mathrm{C}\left(31 \pm 4^{\circ} \mathrm{F}\right)$. Every 90 minutes of heat pump running time, contacts on the defrost timer close for 10 seconds; if the defrost thermostat contacts are closed during those 10 seconds, the unit enters the defrosting mode.

The unit remains in the defrost period (cooling mode) until the temperature of the outdoor coil reaches $18.3 \pm 3.3^{\circ} \mathrm{C}\left(65 \pm 6^{\circ} \mathrm{F}\right)$, or $10 \mathrm{~min}$ have elapsed. Normally the frost is removed before the 10 min limit has been reached. At the end of the defrost interval, the unit is switched to the heating mode and the outdoor fan motor unit starts again. 
Table 3.1. Principal features of test unit

\begin{tabular}{|c|c|}
\hline Refrigerant & $R-22$ \\
\hline Compressor & $\begin{array}{l}\text { Hermetically sealed. compressor and motor } \\
\text { Two-piston, reciprocating } \\
65.3 \times 10^{-6}-\mathrm{m}^{3}\left(3.986-\mathrm{in} .{ }^{3}\right) \text { displacement } \\
0.0413-\mathrm{m}(1.625-\mathrm{in} .) \text { bore; } 0.0244-\mathrm{m} \\
(0.961-\text { in.) stroke } \\
\text { Two-pole motor, } 58.3 \mathrm{rps}(3500 \mathrm{rpm}) \text { nomi- } \\
\text { nal speed }\end{array}$ \\
\hline Outdoor coil & $\begin{array}{l}\text { Aluminum plate fin and tube with return } \\
\text { bends, } 1.3 \text { rows deep (avg.), } 748 \text { fins } / \mathrm{m} \\
\text { (19 fins/in.) } \\
0.975-\mathrm{m}^{2}\left(10.5-\mathrm{ft}^{2}\right) \text { face area } \\
5-\mathrm{blade}, 0.470-\mathrm{m}(18.5-\text { in.) propel ler fan } \\
1.32 \mathrm{~m}^{3} / \mathrm{s}(2800 \mathrm{cfm}) \text { nominal airflow }\end{array}$ \\
\hline Indoor coil & $\begin{array}{l}\text { Aluminum plate fin and tube with return } \\
\text { bends, } 3 \text { rows deep, } 512 \text { fins/m }(13 \\
\text { fins/in.) } \\
0: 294-\mathrm{m}^{2} \cdot\left(3.16-\mathrm{ft}^{2}\right) \text { face area } \\
\text { Forward-vane squirrel-cage fan rotor } \\
0.543 \mathrm{~m}^{3} / \mathrm{hr}(1150 \mathrm{~cm}) \text { nominal airflow } \\
\text { Rotor } 0.267-\mathrm{m}(10.5-i \mathrm{n} .) \text { pitch diameter, } \\
0.229-\mathrm{m} \text { (9-in.) long, double suction }\end{array}$ \\
\hline Controls & $\begin{array}{l}\text { Orifice-type refrigerant flow control } \\
\text { and bypass valves for both heating and } \\
\text { cooling } \\
\text { Time-temperature defrost control } \\
\text { Four-way refrigerant reversing valve. }\end{array}$ \\
\hline Accumulator & One, in refrigerant suction 1 ine. \\
\hline Rated Capacity & $\begin{array}{l}\text { 1. } 9.08 \mathrm{~kW}(31,000 \mathrm{Btu} / \mathrm{hr}) \text { cooling at } \\
35^{\circ} \mathrm{C}\left(95^{\circ} \mathrm{F}\right) \\
\text { 2. } \\
9.96 \mathrm{~kW}(34,000 \mathrm{Btu} / \mathrm{hr}) \text { heating at } \\
8.3^{\circ} \mathrm{C}\left(47^{\circ} \mathrm{F}\right) \\
\text { 3. } \\
5.42 \mathrm{~kW}:(18,500 \mathrm{Btu} / \mathrm{hr}) \text { heating at } \\
-8.3^{\circ} \mathrm{C}\left(17^{\circ} \mathrm{F}\right)\end{array}$ \\
\hline Rated COP & $\begin{array}{l}2.5 \text { at } 8.3^{\circ} \mathrm{C}\left(47^{\circ} \mathrm{F}\right) \mathrm{db} \\
1.7 \text { at }-8.3^{\circ} \mathrm{C}\left(17^{\circ} \mathrm{F}\right) \mathrm{db}\end{array}$ \\
\hline
\end{tabular}




\section{DESCRIPTION OF TEST APPARATUS}

\subsection{Test Loops}

The indoor and outdoor units of the heat pump were placed in separate "bootstrap" air loops that allowed for measurement and control of the temperature and humidity of air reaching the two units and provided the means for measurement of the airflow rates. The loops were constructed so that air could be recirculated after discharge from the fan-coil units and tempered, when necessary, with bleed air or supplemental heat. For the indoor unit, room air was introduced into the air loop to compensate for the heat rejected from the coil. Air pressure drops within that loop were small enough that desired airflow rates could be established by the fan in the indoor unit without recourse to booster fans.

For the steady-state (nonfrosting) tests, air from outside the building was induced into the outdoor-unit air loop. This air was tempered with air from the laboratory space both in order to compensate for heat absorbed by the coil and to reach temperatures higher than the ambient. Both sources provided air that was dry enough to preclude frosting. During the frosting tests, low temperatures and high humidity. levels were desired at the outdoor coil. Accordingly, the air loop was sealed so that all of the air passing over the cold coil was recirculated; humidity was controlled by injecting steam into the air loop.

It was necessary to include a supplementary "booster" fan in the outdoor air loop to overcome the pressure drops due to the ducting. Thus, the airflow rates required for the outdoor unit could be established without penalizing the unit by requiring extra work from the outdoor fan motor. However, it was not possible in these tests to keep the airflow rates as close to the rated value of $1.32 \mathrm{~m}^{3} / \mathrm{s}(2800 \mathrm{cfm})$ as would be desired. Observed airflows were as much as $15 \%$ higher than the rated value during some of the tests because the speed of the booster fan could not be adjusted. In order to evaluate the effect of this deviation on other measured parameters, the ORNL heat pump mode ${ }^{2}$ was used to calculate the magnitudes of changes expected for 10 and $20 \%$ increases in outdoor airflow rates. The heating capacity, compressor motor power 
consumption, and indoor fan motor power consumption were seen to change by 1 ess than $2 \%$. Power consumption by the outdoor fan motor would increase if that fan were required to move more air. However, the booster fan is supplying the additional airflow, so errors caused by airflow rates in excess of the rated value are expected to be less than $5 \%$. The change in the refrigerant evaporating temperature is expected to be less than $0.5^{\circ} \mathrm{C}\left(1^{\circ} \mathrm{F}\right)$.

Schematic diagrams of the two air loops are shown in Figs. 4.1 and 4.2; Fig. 4.3 is a photograph of the test loops. A schematic diagram of the refrigerant circuit is shown in Fig. 4.4.

\subsection{Instrumentation}

\subsubsection{Temperature}

Temperatures were monitored by chromel-alumel and copper-constantan thermocouples, with automatic readout and conversion by the data acquisition system (DAS) described in Sect. 4.3. Refrigerant temperatures were measured by thermocouples taped and clamped to the refrigerant lines and covered with foamed elastomer insulation. Air temperatures were measured by thermocouple grids at appropriate locations.

The typical readout scheme uses a floating reference junction and automatic correction for instrument drift, noted schematically in Fig. 4.5. The floating reference junction temperature is monitored by a highly accurate platinum-nickel resistance temperature detector (RTD); its reading is corrected for drift by referencing it to a precision resistor which has a very small temperature coefficient of resistivity. The thermocouple output signal as seen by the DAS is a function of the reference junction temperature as well as the thermocouple junction temperature. It was found that the NBS temperature vs millivolt relationships ${ }^{3}$ could easily be approximated to within $0.11^{\circ} \mathrm{C}\left(0.2^{\circ} \mathrm{F}\right)$ with reference junction temperatures between 21.1 and $32.2^{\circ} \mathrm{C}\left(70\right.$ and $\left.90^{\circ} \mathrm{F}\right)$ and thermocouple junction temperatures between -12.2 and $65.6^{\circ} \mathrm{C}\left(10\right.$ and $\left.150^{\circ} \mathrm{F}\right)$. The expressions used were: 


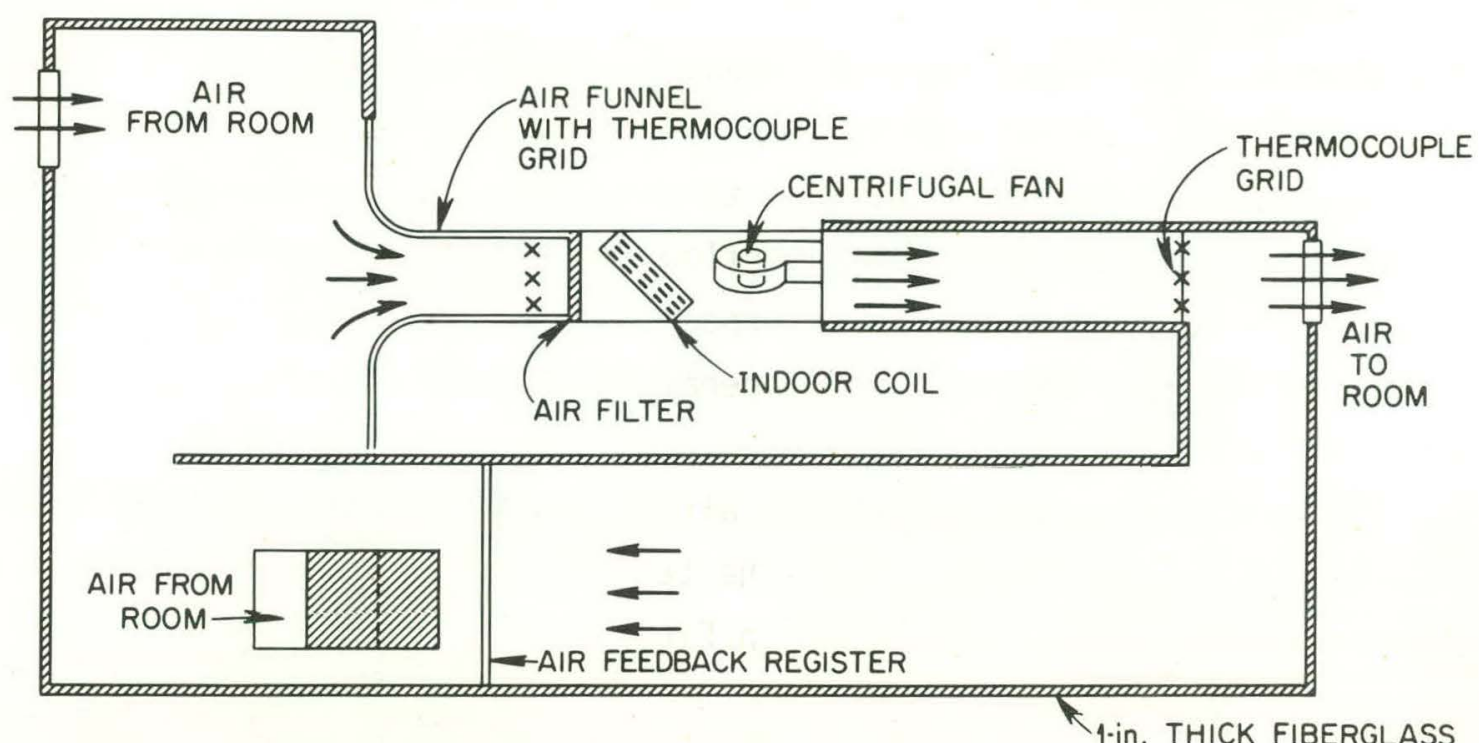

Fig. 4.1. Schematic diagram of test loop for the indoor unit.

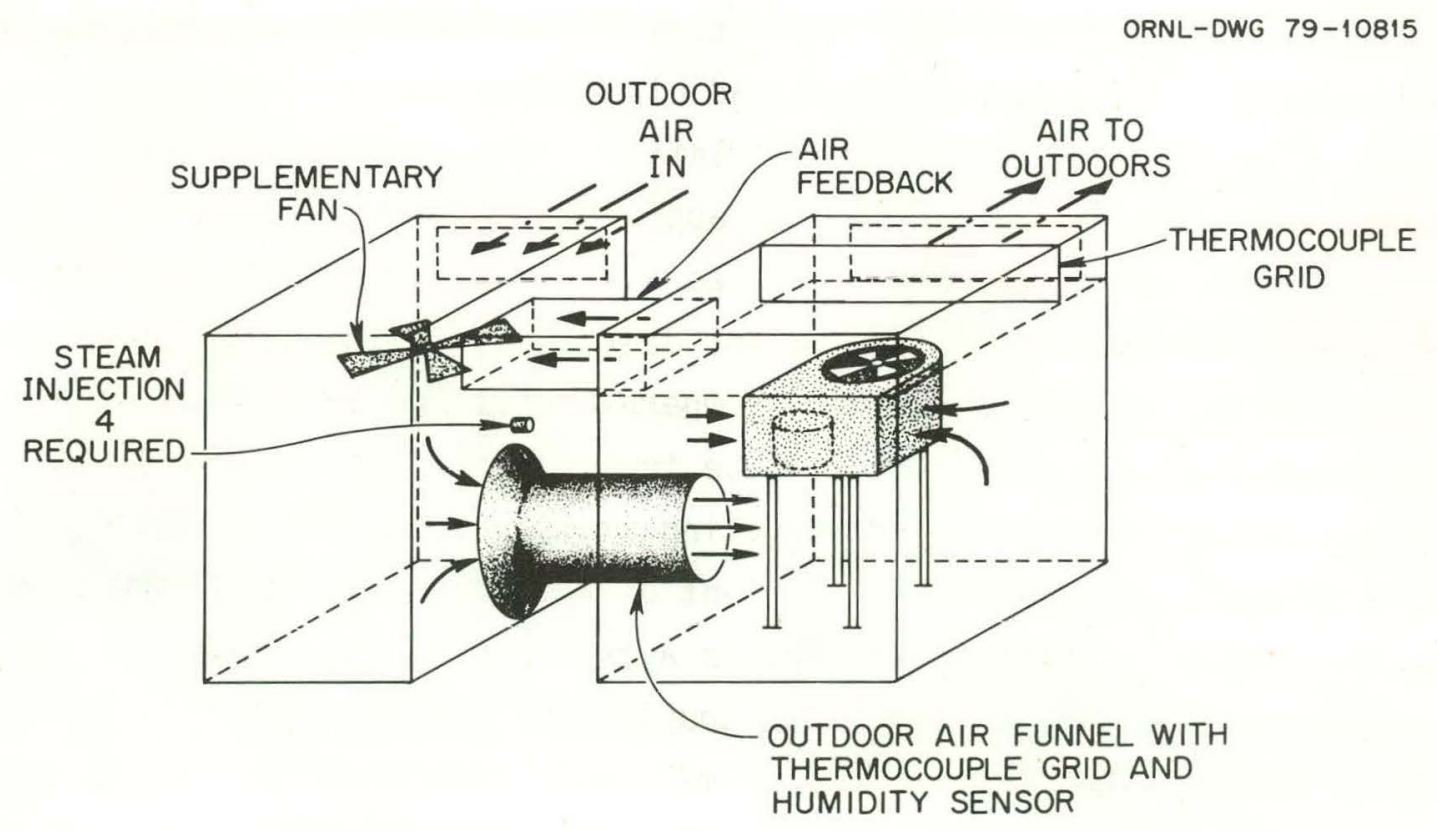

Fig. 4.2. Schematic diagram of test loop for the outdoor unit. 


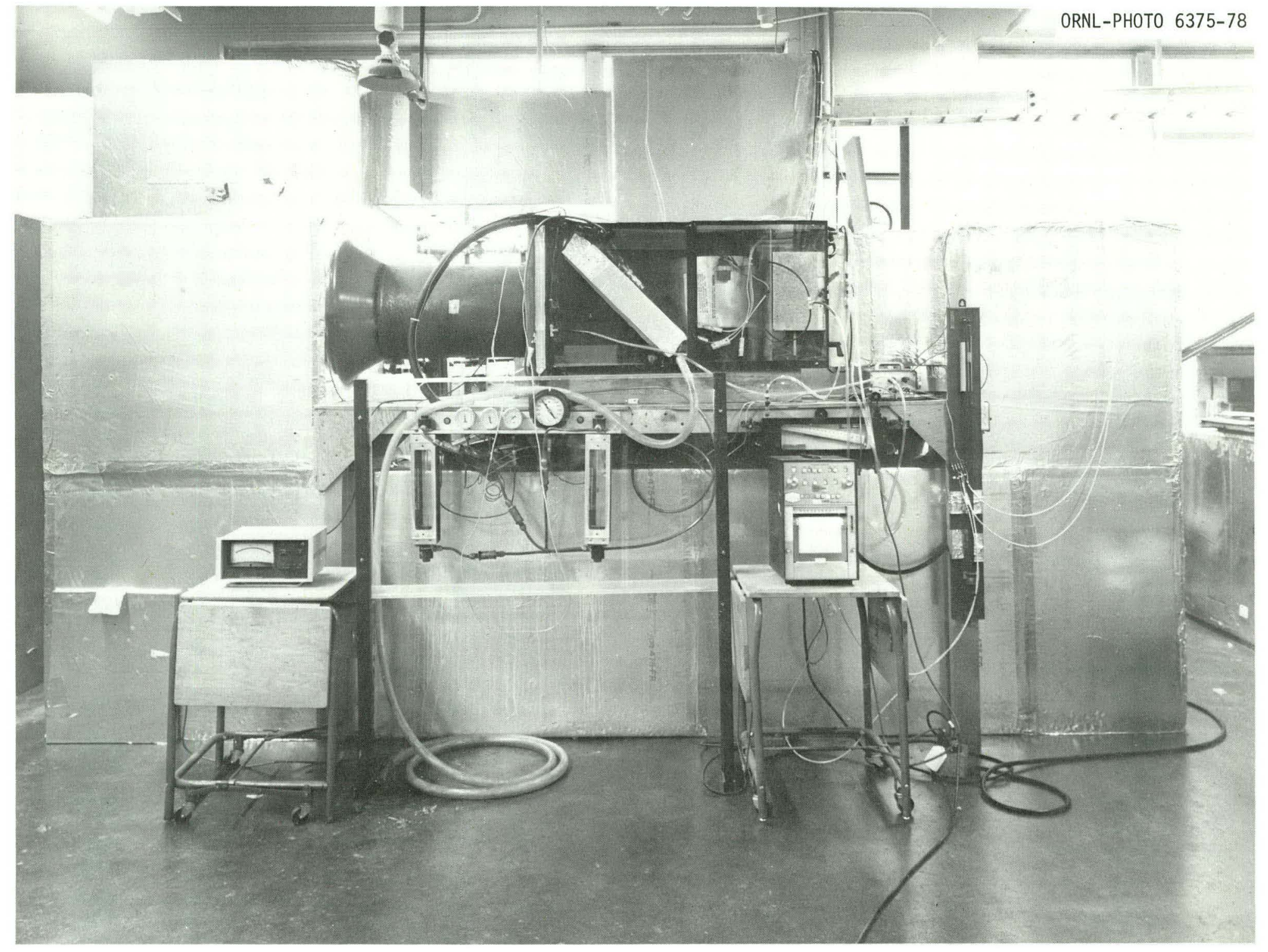

Fig. 4.3. Experimental apparatus. 


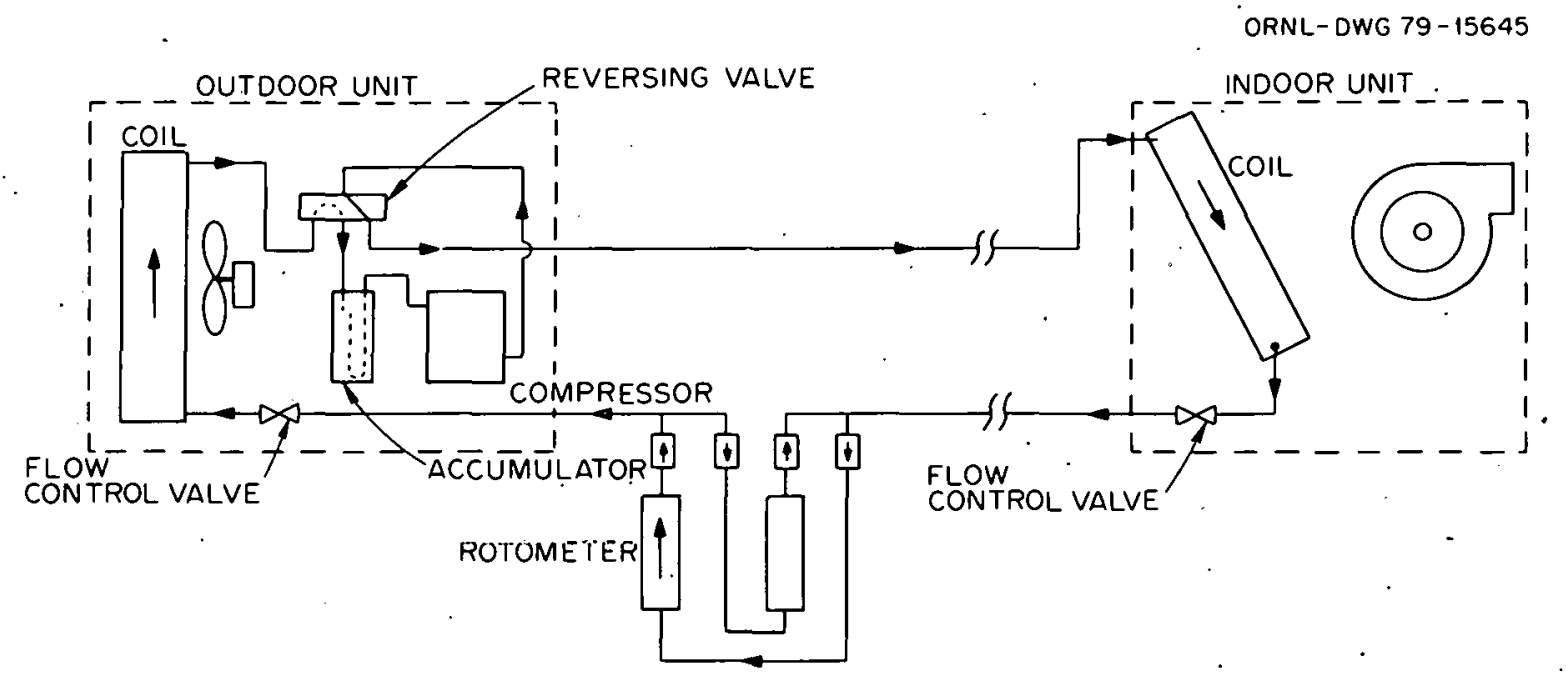

Fig. 4.4. Schematic diagram of refrigerant circuit for the heat pump in the heating mode.

ORNL-DWG 79-10816

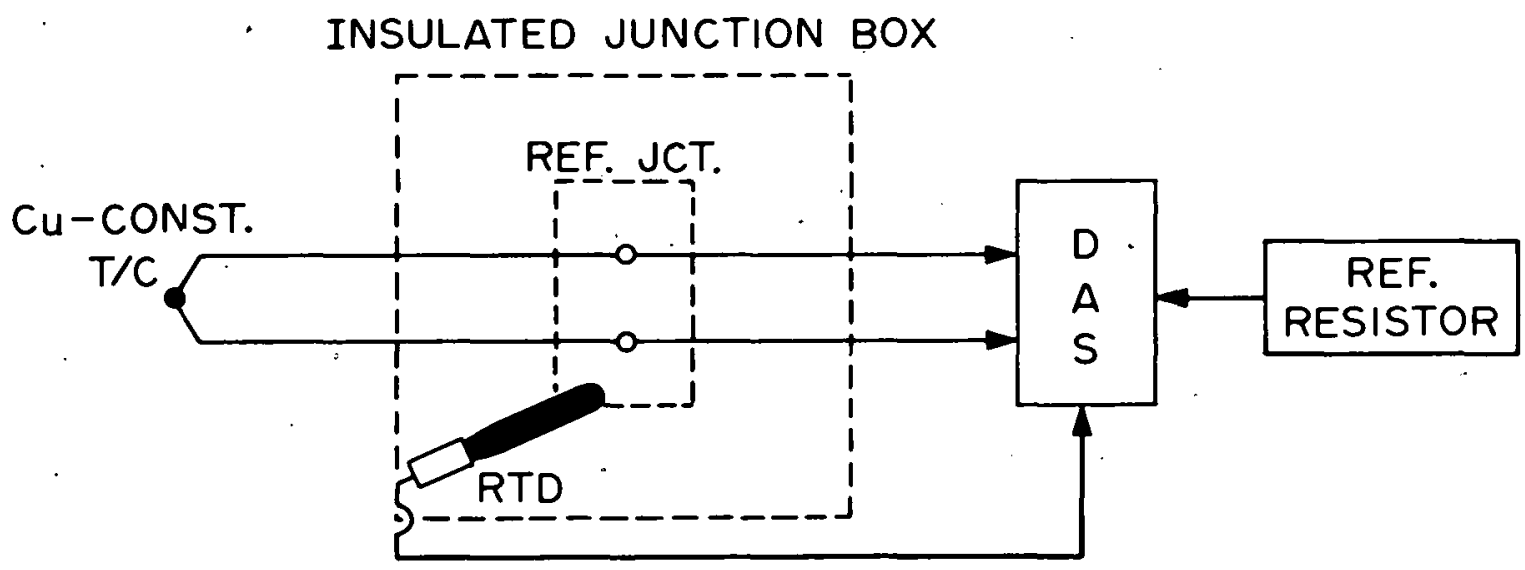

Fig. 4.5. DAS temperature measurement scheme. 


$$
\begin{aligned}
& \left.T=T_{R}+\left(46.1-0.02 T_{R}\right) V-0.414 \mathrm{~V}^{2}, \quad \text { (chromel-alume } 1\right) . \\
& T=T_{R}+\left(48.2-0.05 T_{R}\right) V-1.11 \mathrm{~V}^{2}, \quad \text { (copper-constantan) }
\end{aligned}
$$

where

$$
\begin{aligned}
T & =\text { thermocouple junction temperature, }{ }^{\circ} \mathrm{F} ; \\
T_{R} & =\text { reference junction temperature as measured by the RTD, }{ }^{\circ} \mathrm{F} ; \\
V & =\text { DAS input signal, mV. }
\end{aligned}
$$

The floating reference junction provides advantages compared to a standard temperature-controlled reference box. Errors due to cycling of the control of the box temperature, typically about $\pm 7^{\circ} \mathrm{F}$, are avoided, and the cost is much reduced.

\subsubsection{Pressure}

Steady-state refrigerant pressures were measured using bourdon-type gages and strain-gage-type dynamic pressure transducers located at the compressor-shell inlet and outlet, as well as the condenser inlet and outlet.

\subsubsection{Refrigerant flow rate}

Two rotameters in the refrigerant liquid line were used to determine refrigerant mass flow rate. Check valves were placed in the circuit so that one rotameter was operative in the heating mode and the other in the cooling mode. It was judged that the modest (less than $10 \mathrm{in.} \mathrm{of}$ water column) pressure drop introduced by these meters and check valves would not affect performance of the unit significantly.

\subsubsection{Airflow rate}

Airflow rates in the bootstrap loops were measured by velocity probe traverses using a hot-wire anemometer. The measurements were made at the air funnels installed in the testing loops for this purpose. 


\subsubsection{Electrical power input}

Power to the compressor and each of the two fans was measured separately using thermal-watt converters, which produce d-c signals proportional to the instantaneous power consumption. The original heat pump controls were modified so that each component could be operated manualiy and the defrost cycle could be started and stopped manually.

\subsubsection{Humidity}

The humidity of the air reaching the outdoor coil was monitored by a hygrosensor placed in the air loop upstream of the outdoor unit. The hygrosensor used is one that changes its electrical resistance with the humidity of the air.

\subsection{DAS and Program}

The DAS in the energy conservation laboratory consists of a Digital Equipment Corp. (DEC) PDP-8E digital computer with an 8K-word core memory, a Vidar integrating digital voltmeter with an ohms converter; and a reed relay scanner. The programs used by the computer were written in a DEC FOCAL language modified locally to facilitate data aquisition. The use of an on-line computer system aids the experimenter considerably by giving almost immediate feedback of the heat pump status and performance, . heat balances, and indications of drift of the process variables or component malfunction. Typically, multiple scans are taken over a prescribed period to obtain time-averaged parameters.

Simple routines for calculating the thermodynamic properties of refrigerant $(R-22)$ and for instrument calibrations were developed and incorporated into the computer program. The computed results are found to be well within the expected accuracy ranges of the basic measurements. The R-22 property routines used are given in Appendix C; flow charts of the entire program are shown in Appendix $D$.

Most of the computations made in the FOCAL programs are straightforward and can be understood by reading the flow charts in Appendix $D$. 
The calculation of compressor efficiency included in the program may be an exception. The definitions used in that calculation are for an isentropic compressor efficiency based on knowledge of the refrigerant conditions at the compressor entry and exit.ports. The experimentally measured temperatures and pressures are, however, those at the entry and exit of the shell that contains the compressor and. motor. Because of the thermal losses from the shell and the transfer of heat from the discharge line and the motor to the suction gas, the calculation of efficiency by this method is approximate, but is included to monitor the stability of compressor performance under varying test conditions. Compressor efficiency, $n$, is calculated in the program as the ratio of the change in enthalpy for ideal compression to the actual enthalpy increase:

$$
n=\left(h_{0}^{i}-h_{i}\right) /\left(h_{0}-h_{j}\right)
$$

where $h_{0}$ is the enthalpy at compressor outlet, and $h_{j}$ the enthalpy at inlet. The ideal enthalpy at outlet, $h_{0}^{i}$, is computed as:

$$
h_{0}^{i}=h_{0}-\left.\left(s_{0}-s_{i}\right) \frac{\partial h / \partial T}{\partial s / \partial T}\right|_{0}
$$

in which $s_{0}$ and $s_{i}$ are the entropy at outlet and inlet, and the derivatives with respect to temperature, $T$, are evaluated at outlet conditions. The enthalpies and entropies are calculated from $h_{g}$ and $s_{g}$, the values for saturated vapor, using the amount of superheat, $T_{i}-T_{s}$, where $T_{s}$ is the saturation temperature:

$$
\begin{aligned}
& h_{i}=h_{g}+(\partial h / \partial T)_{p}\left(T_{i}-T_{s}\right) ; \\
& s_{j}=s_{g}+(\partial S / \partial T)_{p}\left(T_{i}-T_{s}\right) .
\end{aligned}
$$

The outlet quantities, $h_{0}$ and $s_{0}$, are similarly calculated using the $h_{g}$ and $s_{g}$ at outlet conditions. The partial derivatives, $\partial T_{s} / \partial T, \partial h / \partial T$, and $\partial S / \partial T$ are calculated at the observed temperatures and pressures using the functions described in Appendix C. 


\section{TEST PROCEDURE}

\subsection{Steady-State Tests}

Tests were conducted to investigate the response of performance parameters to change of the outdoor air temperature while the heat pump was operating in the steady-state heating mode. Tests were run at outdoor air temperatures of $-4,-2,4,9$, and $14^{\circ} \mathrm{C}(24,29,39,48$, and $\left.57^{\circ} \mathrm{F}\right)$.

Steady-state tests were conducted by operating the unit until stable temperatures were achieved, and then taking data. For steady-state measurements it was desired that the system be operating in the heating mode with the outdoor coil operating in an essentially unfrosted condition. Visual observation of the outdoor heat exchanger indicated that nonfrosting operation was indeed achieved.

\subsection{Frosting-Defrosting Tests}

The frosting-defrosting tests were conducted at outdoor air temperatures of approximately $-2^{\circ} \mathrm{C}\left(28^{\circ} \mathrm{F}\right)$ and $1^{\circ} \mathrm{C}\left(33^{\circ} \mathrm{F}\right)$ with the relative humidity ranging from 80 to $100 \%$. It was judged that these temperatures and humidities represent severe frosting conditions pertinent to the evaluation of the performance degradation of the unit under frosting-defrosting operation.

1 The test at $100 \%$ relative humidity of the outdoor air allowed fog to reach the outdoor coil because the steam was injected into the airstream very close to the outdoor unit, thus preventing the possibility of only saturated vapor reaching the outdoor heat exchanger. The tests at about $100 \%$ relative humidity were conducted for about 50 min while the $80-85 \%$ relative humidity and $92-97 \%$ relative humidity tests were conducted for 80 to $100 \mathrm{~min}$. The tests were terminated when the airflow rates dropped to about $20 \%$ of nominal value. 


\subsection{Fan Tests}

Tests were conducted to measure the fan motor efficiencies of both the indoor and outdoor units. The air-moving units were operated in the air loops of the testing rig, that is, in situ, but with the hermetic compressor unit turned off.

\subsection{Refrigerant Charge Tests}

The influence of the refrigerant charge on the performance of this heat pump system in the heating mode was evaluated by varying the charge from 63 to $127 \%$ of the value specified by the manufacturer. The experiments were conducted while maintaining an outdoor air temperature of about $10^{\circ} \mathrm{C}\left(50^{\circ} \mathrm{F}\right)$ dry bulb and a $21.1^{\circ} \mathrm{C}\left(70^{\circ} \mathrm{F}\right)$ indoor air dry bulb temperature.

The effect of variations of the refrigerant charge was first observed with the rated value of $2.86 \mathrm{~kg}(6 \mathrm{lb}, 5 \mathrm{oz})$ of refrigerant in the system, then overcharging the unit with successively larger amounts of refrigerant up to $3.63 \mathrm{~kg}(8 \mathrm{lb})$. The undercharge tests were run subsequently, also stepwise, down to $1.81 \mathrm{~kg} .(4 \mathrm{lb})$ charge. The test was concluded after observing bubbles in the refrigerant stream rotameter when the charge was dropped to $1.67 \mathrm{~kg}(3 \mathrm{lb}, 11 \mathrm{oz})$. 


\section{STEADY-STATE TEST RESULTS}

Heating capacity and COP, expressed as functions of the ambient temperature, are the descriptors most often presented to characterize the operation of a particular heat pump; indeed, they are essential data in applications considerations. Of greater interest in a study directed toward improving the efficiency and reliability of heat pumps, however; is the measurement of the performance of the individual components that make up the heat pump. Accordingly, a prime goal of this experiment was the collection of performance data on the major components. Characterization of fan, heat exchanger, and compressor performance are included as well as that of system heat losses. The steady-state test data are presented in Appendix A.

\subsection{Heating Capacity and COP}

We define the heating capacity of the heat pump as the sum of the heat rejected by the indoor coil and the power.input to the indoor fan. The heating efficiency, or COP, of the heat pump is defined as the ratio of heating capacity to total power input. The latter includes the power to both indoor and outdoor fans and the power to the compressor motor. The measured heating capacity and COP as functions of outdoor air temperature are shown in Figs. 6.1 and 6.2. The graphs represent the functions as determined by two methods: one is based on the flow and temperature rise of the indoor air, the other on the flow and enthalpy change of the refrigerant plus the power input to the indoor fan. The smooth curves are second order curve fits to the data derived from experiment. Shown also, for comparison, are the values for this unit published by the Air Conditioning and Refrigeration Institute (ARI) at the established rating points of $-8.3^{\circ} \mathrm{C}\left(17^{\circ} \mathrm{F}\right)$ and $8.3^{\circ} \mathrm{C}\left(47^{\circ} \mathrm{F}\right)$ as previously discussed in Sect. 2.1. The heating capacity and COP computed from airside measurements average about $8 \%$ higher than those from the refrigerant method and are more scattered because of the.greater difficulty in measuring air flows and temperatures. The standard error in heating capacity is $\pm 0.22 \mathrm{~kW}$ 


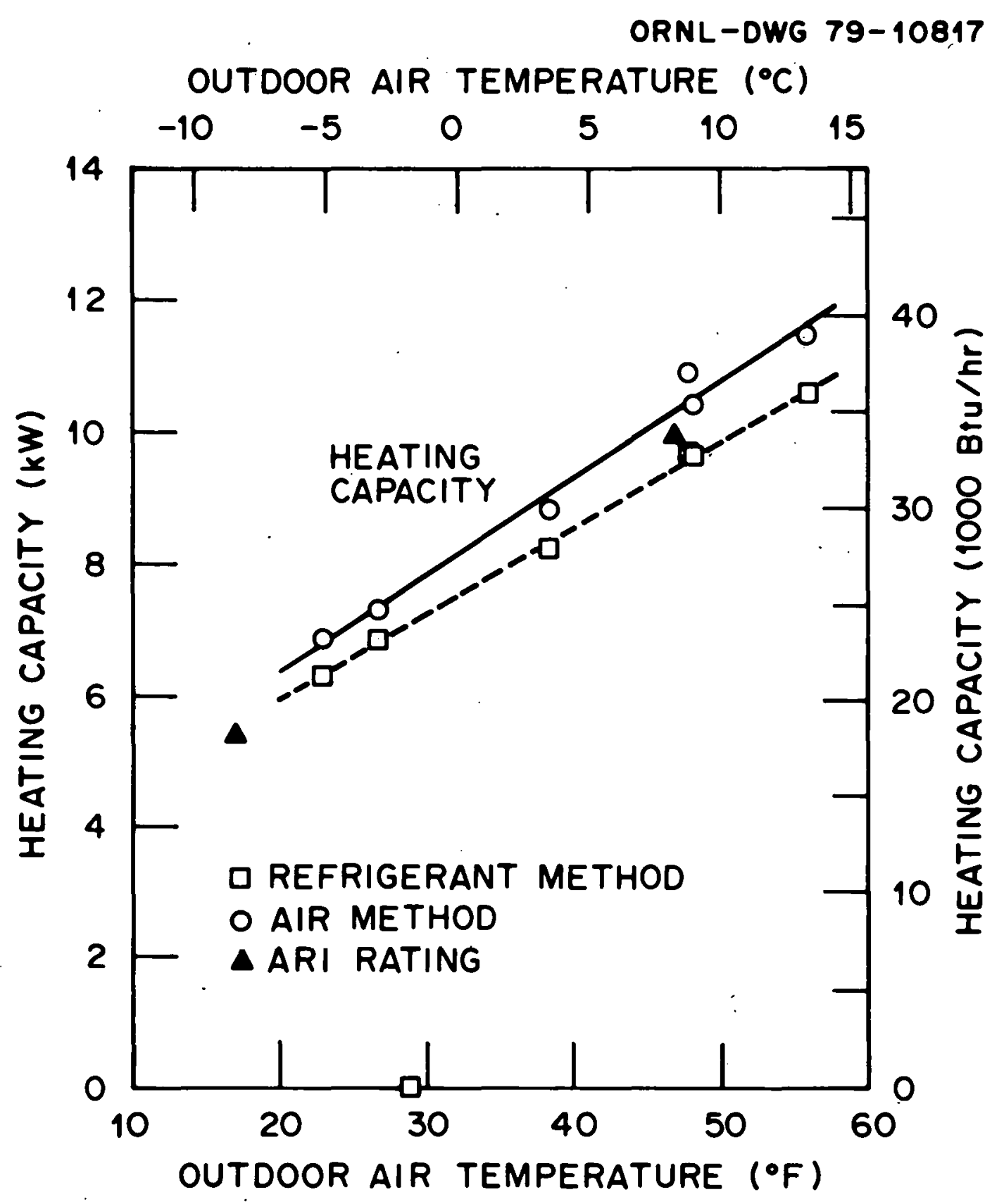

Fig. 6.1. System heating capacity as a function of outdoor air temperature. 


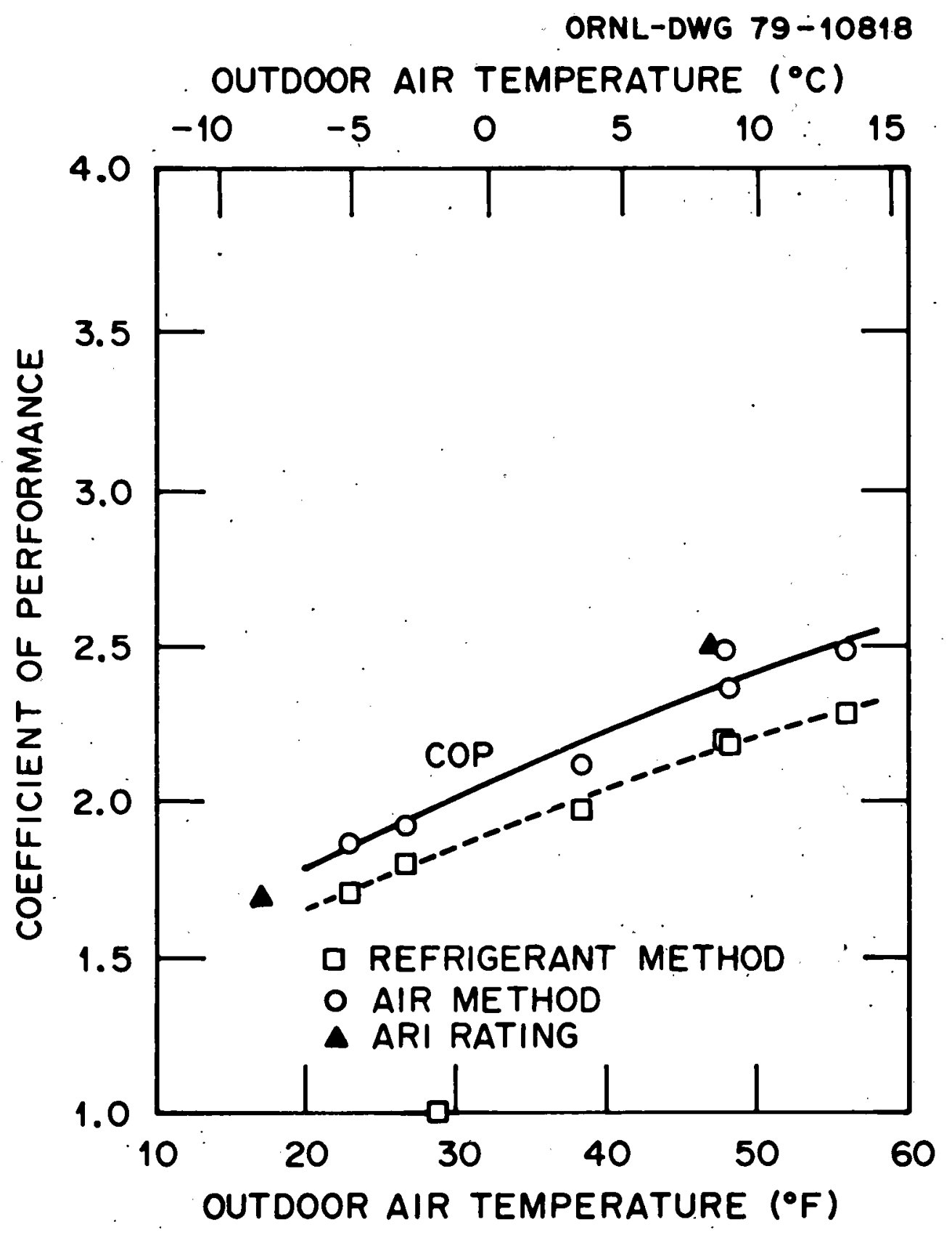

Fig. 6.2. System coefficient of performance as a function of outdoor air temperature. 
for the air method and $\pm 0.07 \mathrm{~kW}$ for the refrigerant method; the corresponding measures of fit for the COP are \pm 0.06 and \pm 0.02 respectively.

Figure $6: 3$ depicts the total power input to the heat pump system as a function of outdoor air temperature. The observed power consumption at the higher rating point is $7.4 \%$ more than the ARI value; this same difference shows up in comparison of the computed COP (Fig. 6.2) with that from ARI. There is close agreement in the heating capacity at the higher rating point. No comparison, except by extrapolation, can be made at the lower rating point because limitations of the testing equipment precluded measurements at that temperature. Changes in heating capacity due to variations in the relative humidity of the outdoor air (within the non-frosting range) were not investigated.

Figures 6.1 and 6.2 show the typical characteristic of vaporcompression heat pump systems, that is, decreasing heating capacity and COP with decreasing outdoor air temperatures. The reduced heating capacity at lower ambient temperatures is due to the decrease in suction-gas density and the corresponding reduction in refrigerant mass flow rate as a consequence of the reduced outdoor coil temperatures. The decrease in the COP is mainly due to the increase in the compressor pressure ratio, which results in an increased power input to the system per unit mass flow of refrigerant.

\subsection{Fan Performance}

\subsubsection{Indoor-unit fan}

The indoor-unit fan is driven by a three-speed motor; the speeds are listed by the manufacturer as 950,850 , and $750 \mathrm{rpm}$. The actual fan speeds checked in our laboratory were essentially the same for the high and medium speed settings.

Figure 6.4 shows the results of the indoor fan evaluation at the high and medium speeds; no characteristic curves were obtained for the low. speed setting. The efficiency shown is defined as the ratio of the delivered air power to the electrical power input to the fan motor. It represents the combined efficiency of the fan and motor, i.e., the 


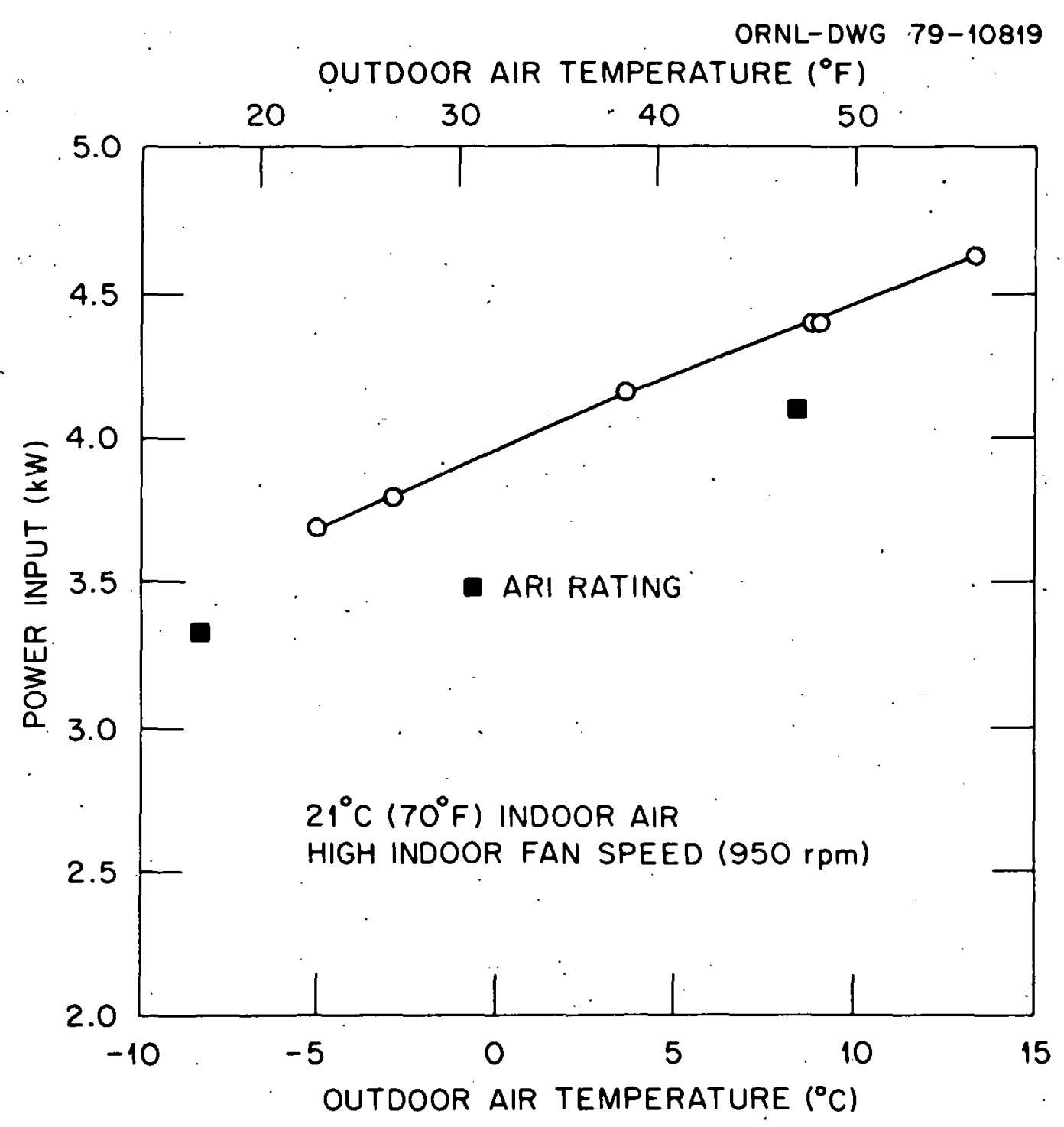

Fig. 6.3. Power input as a function of outdoor air temperature. 


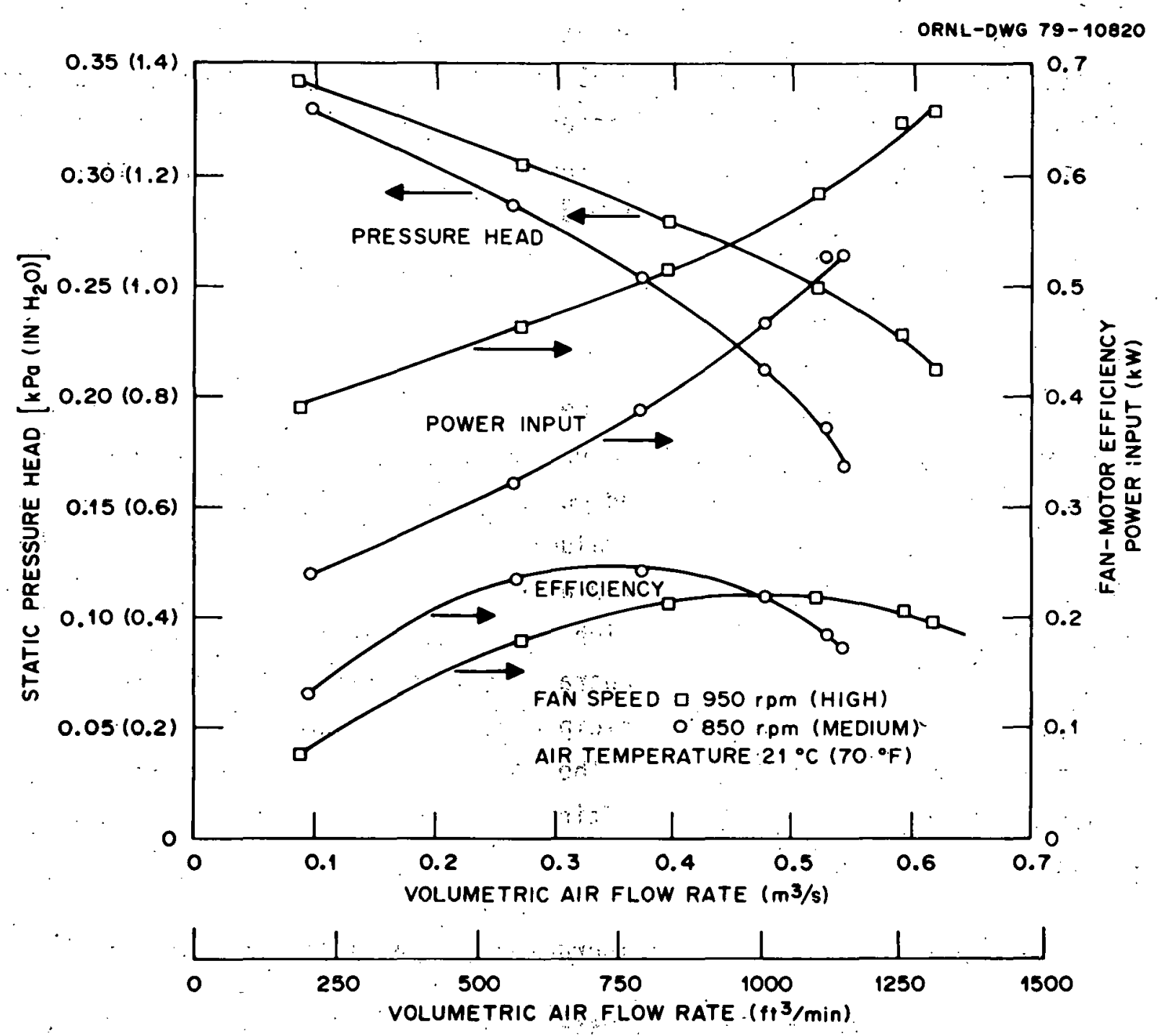

Fig. 6.4. Indoor fan characteristics. 
product of the separate efficiencies. In the case of the indoor fan, this efficiency peaks at a value of about 0.25 at an airflow rate of about $0.35 \mathrm{~m}^{3} / \mathrm{s}\left(750 \mathrm{ft}^{3} / \mathrm{min}\right)$ at the medium speed setting of the fan. For the high speed setting, $950 \mathrm{rpm}$, the efficiency peaks at about $0.50 \mathrm{~m}^{3} / \mathrm{s}$ $\left(1050 \mathrm{ft}^{3} / \mathrm{min}\right)$, with a value of about 0.22 . The flow rates used in the system tests range from 0.51 to $0.55 \mathrm{~m}^{3} / \mathrm{s}$ (1080 to $1150 \mathrm{ft}^{3} / \mathrm{min}$ ), reasonably close to the rate for maximum efficiency at high speed of the fan and motor combination installed in the unit, and within the range of flow, rates suggested by the manufacturer. The data from the tests of fan performance are shown in Appendix B.

\subsubsection{Outdoor-unit fan}

Figure 6.5 shows the performance characteristics of the outdoor-unit fan and motor measured without the pressure drop due to the air circulating loop. For this unit, the combined motor and fan efficiency peaks at about $1.038 \mathrm{~m}^{3} / \mathrm{s}\left(2200 \mathrm{ft}^{3} / \mathrm{min}\right)$ with a value of 0.14 . The rated flow of outdoor air is $1.32 \mathrm{~m}^{3} / \mathrm{s}\left(2800 \mathrm{ft}^{3} / \mathrm{min}\right)$ for a unit installed according to the manufacturer's instructions at which the combined efficiency is 0.11 . The outdoor fan is thus expected to operate at less than peak efficiency for an unfrosted coil. It may be anticipated, however, that frost accumulation on the outdoor coil will increase the resistance to airflow, thereby decreasing the flow rate, and shifting the operation of the fan and motor toward the peak efficiency.

\subsection{Heat Exchanger and Refrigerant Metering Device Performance}

As in the case of the low-first-cost heat pump previously evaluated, 1 the performance data representing the operation of the heat exchangers and the metering device are discussed together because' of the interrelated operation of these components. The condensing pressure is determined by both the restriction of the metering device and the heat transfer capacity of the condenser.

Operating conditions on the evaporator side of the heat pump system are not directly controlled by the metering device; the evaporator 


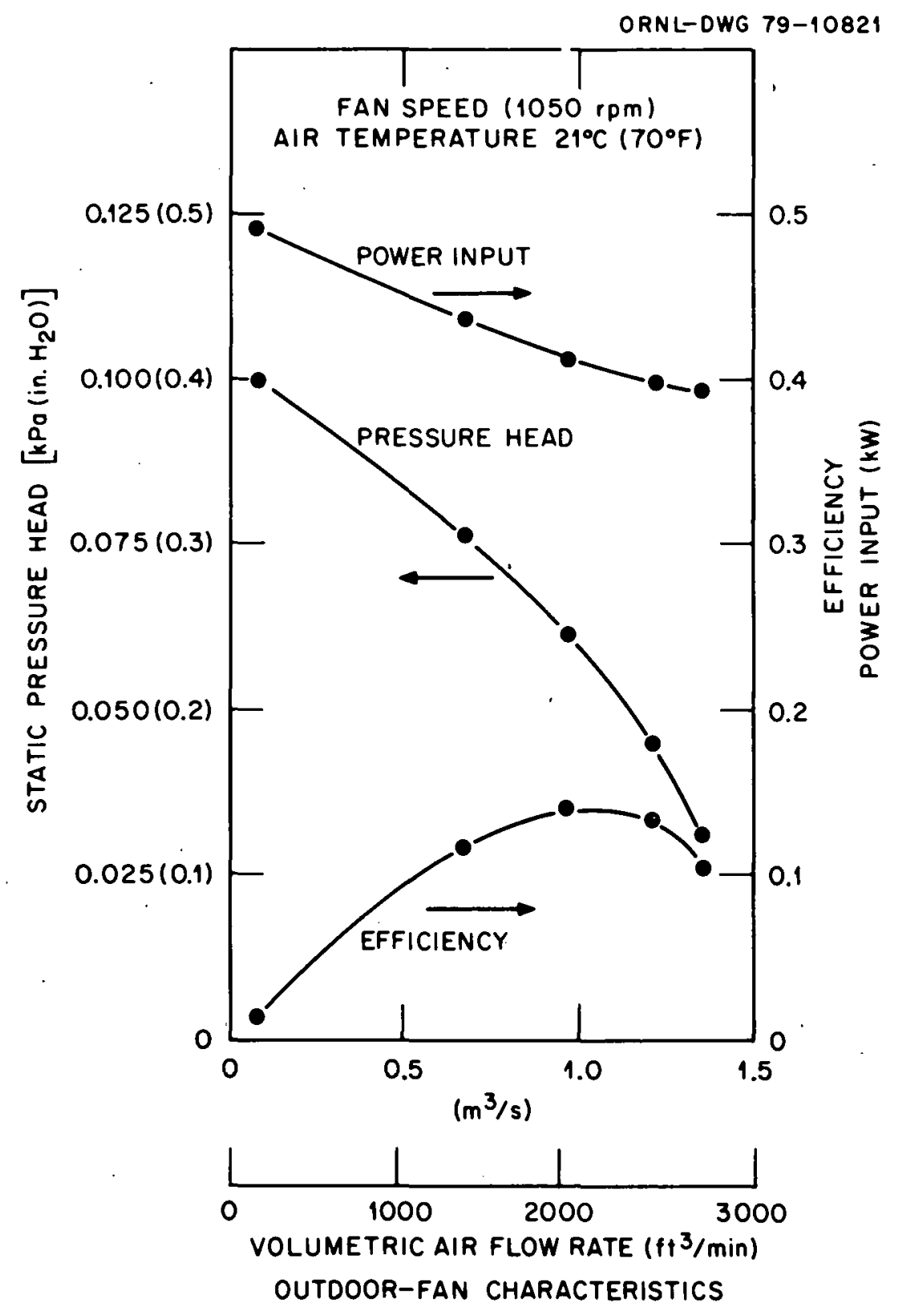

Fig. 6.5. Outdoor fan characteristics. 
reaches a refrigerant temperature-pressure level which allows the flowrate capacity of the compressor to match the flow-rate balance established on the high-pressure side of the system. The presence of a suction-line accumulator that is at least partially filled with liquid refrigerant influences the condition of the refrigerant at the evaporator exit. 'The experimental results show that the superheat at that point never exceeds $2.2 \mathrm{C}^{\circ}\left(4 \mathrm{~F}^{\circ}\right)$ over the range of outdoor temperatures observed in these tests.

\subsubsection{Condenser (indoor coil)}

Table 6.1 shows condenser operating characteristics as a function of outdoor air temperatures ranging from $-5.0^{\circ} \mathrm{C}\left(23^{\circ} \mathrm{F}\right)$ to $13.3^{\circ} \mathrm{C}\left(56^{\circ} \mathrm{F}\right)$. The refrigerant subcooling at exit from the condenser varies from $2.7 \mathrm{C}^{\circ}$ $\left(4.8 \mathrm{~F}^{\circ}\right)$ at the low ambient temperature to $15.7 \mathrm{C}^{\circ}\left(28.3 \mathrm{~F}^{\circ}\right)$ at the high ambient temperature. The difference between refrigerant condensing temperature and mean air temperature (fifth column) varies from 4.9 to $22.6 \mathrm{C}^{\circ}\left(21.5\right.$ to $\left.40.7 \mathrm{~F}^{\circ}\right)$ for the same ambient temperature range. The sixth column shows the difference between the temperature of the refrigerant exiting the coil and the average temperature of the indoor air. This difference varies between 13.7 and $15.4 \mathrm{C}^{\circ}\left(24.7\right.$ and $\left.27.7 \mathrm{~F}^{\circ}\right)$.

The indoor heat exchanger provides five parallel refrigerant circuits as shown in Fig. 6.6. Measurement of returi-bend temperatures reveals that some of these circuits operate with a substantial amount of liquid refrigerant in them. Figure 6.7 shows temperature profiles of one such circuit for four operating conditions. In all four cases the desuperheating is quickly accomplished. At the higher outdoor air temperatures, the two-phase region occupies less than half the circuit, with the subcooling region starting at tube number 10 . For the lower ambients, the condensing region is considerably longer. The temperatures shown on the graph were measured by thermocouples attached to the return bends and covered with foamed elastomer insulation.

\subsubsection{Evaporator (outdoor coil)}

The operating characteristics of the evaporator (outdoor heat exchanger) are presented in Table 6.2 for the same range of outdoor air 
Table 6.1. Steady-state indoor coil (condenser) performance

\begin{tabular}{|c|c|c|c|c|c|}
\hline $\begin{array}{l}\text { Outdoor a ir } \\
\text { temperature } \\
{\left[{ }^{\circ} \mathrm{C}\left({ }^{\circ} \mathrm{F}\right)\right]}\end{array}$ & $\begin{array}{l}\text { Condensing } \\
\text { temperature } \\
{\left[{ }^{\circ} \mathrm{C}\left({ }^{\circ} \mathrm{F}\right)\right]}\end{array}$ & $\begin{array}{c}\text { Exit } \\
\text { subcooling } \\
{\left[\mathrm{C}^{\circ}\left(\mathrm{F}^{\circ}\right)\right]}\end{array}$ & $\begin{array}{c}\text { Heat } \\
\text { transferred } \\
{[\mathrm{kW}(\mathrm{Btu} / \mathrm{hr})]}\end{array}$ & $\begin{array}{l}\text { Mean } \Delta T \\
\text { refrig.-aire } \\
{\left[C^{\circ}\left(F^{\circ}\right)\right]}\end{array}$ & $\begin{array}{l}\text { Minimum } \Delta T \\
\text { refrig. out-air in } \\
{\left[C^{\circ}\left(F^{\circ}\right)\right]}\end{array}$ \\
\hline$-5.1(22.9)$ & $38.4(101.1)$ & $2.7(4.9)$ & $5.67(19,360)$ & $11.9(21.5)$ & $14.3(25.7)$ \\
\hline$-2.9(26.7)$ & $39.6(103.3)$ & $3.9(7.0)$ & $6.21(21,206)$ & $13.0(23.4)$ & $14.7(26.4)$ \\
\hline $3.6(38.4)$ & $45.7(114.2)$ & $9.9(17.8)$ & $7.58 \cdot(25,864)$ & $17.4(31.3)$ & $14.4(26)$ \\
\hline $9.0(48.2)$ & $50.0(122.0)$ & $14.6(26.2)$ & $9.03(30,812)$ & $20.8(37.5)$ & $13.7(24.7)$ \\
\hline $13.3(56.0)$ & $52.2(126.0)$ & $15.7(28.3)$ & $9.94(33,914)$ & $22.6(40.7)$ & $15.4(27.7)$ \\
\hline
\end{tabular}

$a_{\text {Runs }} 6,5,4,2$, and 7 respectively, as listed in Table B.1. Nominal indoor temperature is $21^{\circ} \mathrm{C}\left(70^{\circ} \mathrm{F}\right)$.

$b_{\text {Based on high-side pressure. }}$

${ }^{c}$ Approximate value taken as the difference between condensing temperature and mean air temperature. 


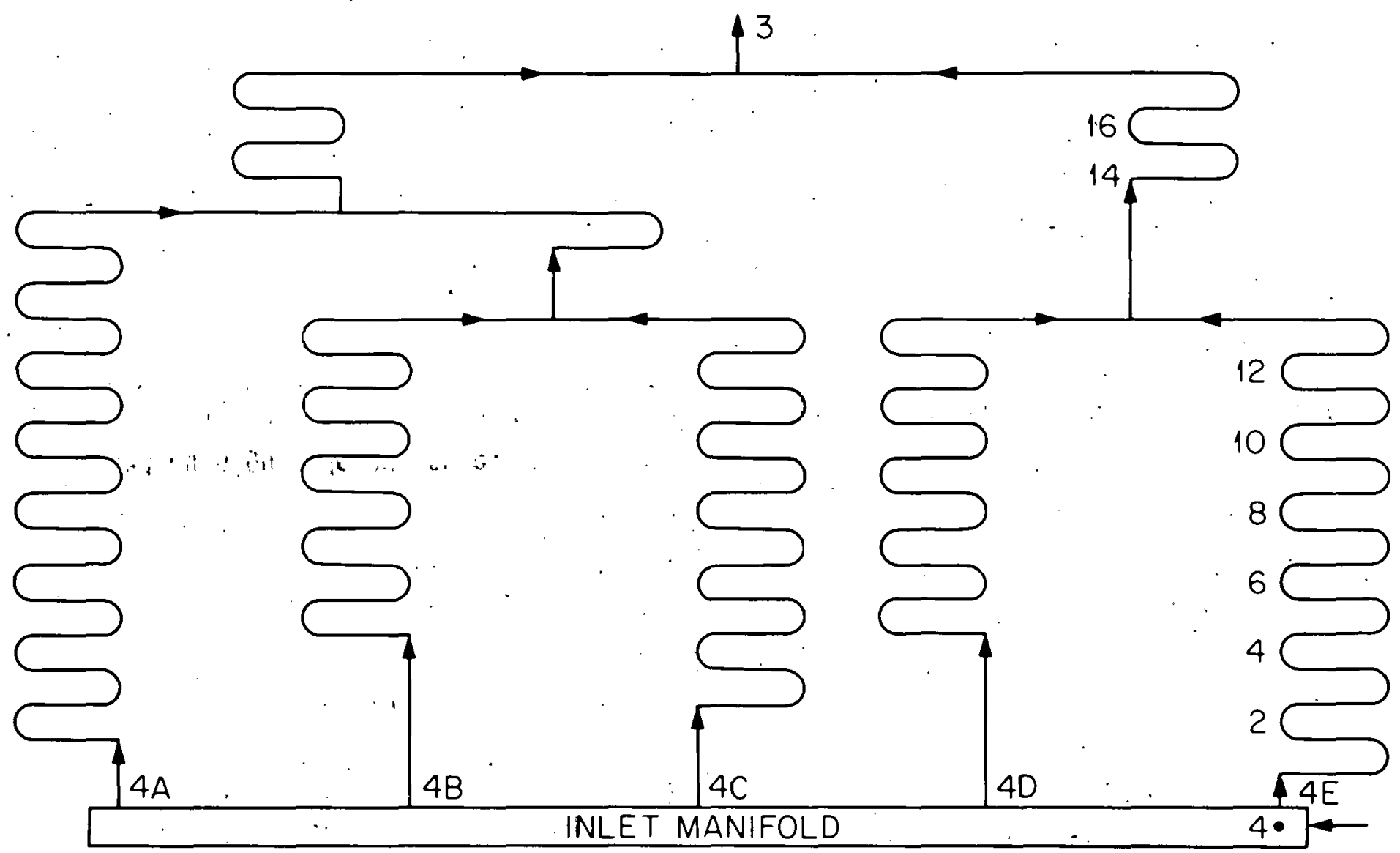

Fig. 6.6. Schematic diagram of the refrigerant circuits in the indoor coil. 


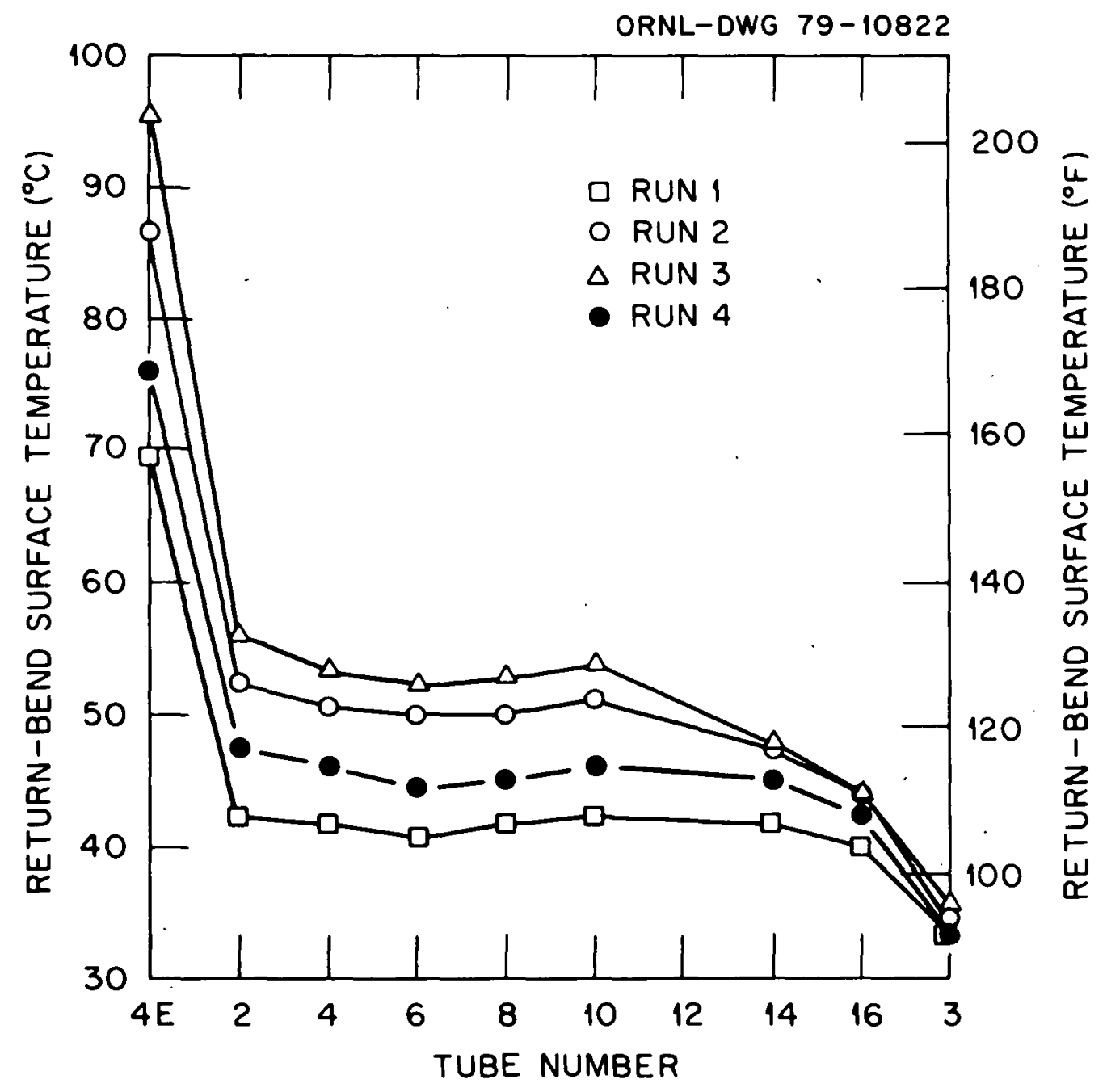

Fig. 6.7. Temperature profiles for one refrigerant circuit of the indoor coil. The outdoor air temperature was $1.0^{\circ} \mathrm{C}\left(33.8^{\circ} \mathrm{F}\right)$ for run 1 , $13.3^{\circ} \mathrm{C}\left(56.0^{\circ} \mathrm{F}\right)$ for $\operatorname{run} 2,18.6^{\circ} \mathrm{C}\left(65.4^{\circ} \mathrm{F}\right)$ for run 3 , and $5.7^{\circ} \mathrm{C}\left(42.3^{\circ} \mathrm{F}\right)$ for run 4 . 
Table 6.2. Steady-state outdoor coil (evaporator) performance

\begin{tabular}{cccccc}
\hline $\begin{array}{c}\text { Outdoor air } \\
\text { temperature } \\
{\left[{ }^{\circ} \mathrm{C}\left({ }^{\circ} \mathrm{F}\right)\right]}\end{array}$ & $\begin{array}{c}\text { Evaporating } \\
\text { temperature } \\
{\left[{ }^{\circ} \mathrm{C}\left({ }^{\circ} \mathrm{F}\right)\right]}\end{array}$ & $\begin{array}{c}\text { Exit } \\
\text { superheat } \\
{\left[\mathrm{C}^{\circ}\left(\mathrm{F}^{\circ}\right)\right]}\end{array}$ & $\begin{array}{c}\text { Heat } \\
\text { transferred } \\
{[\mathrm{kW}(\mathrm{Btu} / \mathrm{hr})]}\end{array}$ & $\begin{array}{c}\text { Mean } \Delta T \\
\text { air-refrig. } \\
{\left[\mathrm{C}^{\circ}\left(\mathrm{F}^{\circ}\right)\right]}\end{array}$ & $\begin{array}{c}\text { Minimum } \Delta T \\
\text { air in-refrig. out } \\
{\left[\mathrm{C}^{\circ}\left(\mathrm{F}^{\circ}\right)\right]}\end{array}$ \\
\hline$-5.1(22.9)$ & $-12.7(9.2)$ & $1.1(2.0)$ & $4.81(16,420)$ & $7.3(13.1)$ & $5.9(10.6)$ \\
$-2.9(26.7)$ & $-10.9(12.4)$ & $0.8(1.5)$ & $5.29(18,049)$ & $7.4(13.3)$ & $.6 .4(11.6)$ \\
$3.6(38.4)$ & $-6.3(20.6)$ & $0.9(1.7)$ & $6.37(21,756)$ & $8.9(16.0)$ & $8.1(14.6)$ \\
$9.0(48.2)$ & $-1.2(29.8)$ & $0(0)$ & $7.51(25,629)$ & $8.7(15.6)$ & $9.4(17.0)$ \\
$13.3(56.0)$ & $-0.2(31.4)$ & $1.9(3.5)$ & $8.08(27,579)$ & $11.3(20.3)$ & $10.8(19.4)$ \\
\hline
\end{tabular}

a Runs $6,5,4,2$, and 7 respectively, as listed in Table B.1. Nominal indoor air temperature is $21^{\circ} \mathrm{C}\left(70^{\circ} \mathrm{F}\right)$.

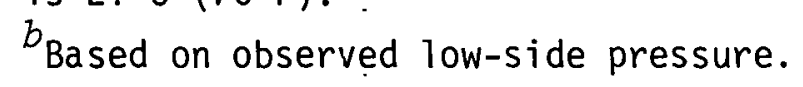

${ }^{c}$ Approximate value taken as the difference between mean air temperature and refrigerant evaporating temperature. 
temperatures as was considered for the indoor coil. The evaporating temperatures; calculated from the observed pressure at the suction line, vary. in the expected manner with changing outdoor temperature. The superheat of the refrigerant at the compressor inlet is sharply limited, probably by: the: presence of liquid refrigerant in the suction-line accumulator.

The approach of refrigerant temperature at the evaporator exit to that of the inlet air is in the expected range for all of the air temperatures at which tests were conducted.

\subsection{System Heat Losses}

.Heat:losses from the system ranged from 14 to $25 \%$ of the observed heating capacity. These losses occur at the compressor shell and discharge line, including the reversing valve. They are compared to the system is heating capacity in Table 6.3.

Table 6.3. System heat loss rates

\begin{tabular}{ccccc}
$\begin{array}{c}\text { Outdoor a } \\
\text { temperature } \\
{\left[{ }^{\circ} \mathrm{C}\left({ }^{\circ} \mathrm{F}\right)\right]}\end{array}$ & $\begin{array}{c}\text { Compressor-sheli } \\
\text { heat rejection } \\
{[\mathrm{kW}(\mathrm{Btu} / \mathrm{hr})]}\end{array}$ & $\begin{array}{c}\text { Discharge line } \\
\text { heat loss ratea } \\
{[\mathrm{kW}(\mathrm{Btu} / \mathrm{hr})]}\end{array}$ & $\begin{array}{c}\text { system } \\
\text { heat capacity } \\
{[\mathrm{kW}(\mathrm{Btu} / \mathrm{hr})]}\end{array}$ \\
\hline$-5.1(22.9)$ & $\cdots$ & $1.17(3994)$ & $0.41(1410)$ & $6.30(21,503)$ \\
$-2.9(26.7)$ & $\because$ & $1.15(3942)$ & $0.44(1489)$ & $6.84(23,357)$ \\
$3.6(38.4)$ & $\cdots$ & $1.22(4170)$ & $-0.45(1436)$ & $8.21(28,014)$ \\
$9.0(48.2)$ & $1.17(3793)$ & $0.52(1773)$ & $9.62(32,822)$ \\
$13.3:(56.0)$ & $0.91(3095)$ & $0.54(1850)$ & $10.57(36,064)$ \\
\hline
\end{tabular}

${ }^{a}$ Includes reversing valve loss.

Heat rejection from the compressor shell is computed as the difference between the electric power input to the compressor motor and the enthalpy ga in of the refrigerant between shell inlet and discharge. This loss ranges from 25 to $45 \%$ of the power input to the compressor motor, and though it possibly may be exaggerated by errors in temperature measurement due to heat conduction in the refrigerant lines near the shel1, 
it is obviously substantial. The loss could be reduced by insulating the compressor shell, but care must be exercised that the resulting increase in internal temperatures in the motor-compressor unit does not cause or contribute to premature failure of the electrical insulation or the lubricant system. Heat losses from the discharge line were calculated from the differences in enthalpy observed at the compressor shell discharge and the condenser inlet. These losses thus include the heat transferred to the suction gas at the reversing valve.

\subsection{Compressor Operation}

Compressor performance parameters for a range of ambient temperatures are shown in Table 6.4. The refrigerant mass flow rate increases with increasing outdoor air temperatures because the suction-line pressure, and therefore the derisity of refrigerant reaching the compressor, increases at the higher ambient temperatures. The increased mass flow rate represents an increased pumping rate of the compressor, which is reflected in the higher power consumption of the compressor motor at the higher temperatures. Conversely, the pressure ratio is seen to decrease as the outdoor air temperature increases. The decrease is rather small, however, because it is controlled by the higher temperature differences that exist at both heat exchangers at the higher ambient temperatures.

The efficiency of the motor and compressor taken together is shown in the fifth column of Table 6.4. This efficiency is calculated as the ratio of the ideal isentropic work to the observed electrical power input, with the ideal isentropic work being calculated from the observed conditions of the refrigerant at entry and the refrigerant pressure at the exit of the hermetically sealed shell containing both motor and compressor. Thus the efficiency quoted accounts for losses in the motor, irreversible thermodynamic losses due to gas throttling at the valves and muffler, suction gas heating by the motor, losses due to mechanical friction, and for internal heat transfer. It should not, of course, be compared with efficiencies based on refrigerant conditions at the suction and discharge ports of the compressor itself. The combined efficiency ranges from 0.44 to 0.49 . 
Table 6.4. Compressor operating characteristics

\begin{tabular}{lccccc}
\hline $\begin{array}{c}\text { Outdoor air } \\
\text { temperature } \\
{\left[{ }^{\circ} \mathrm{C}\left({ }^{\circ} \mathrm{F}\right)\right]}\end{array}$ & $\begin{array}{c}\text { Power input } \\
\text { to motor } \\
{[\mathrm{kW}(\mathrm{Btu} / \mathrm{hr})]}\end{array}$ & $\begin{array}{c}\text { Refrigerant } \\
\text { mass flow rate } \\
{[\mathrm{kg} / \mathrm{s}(1 \mathrm{~b} / \mathrm{hr})]}\end{array}$ & $\begin{array}{c}\text { Pressure } \\
\text { ratio }\end{array}$ & $\begin{array}{c}\text { Combined } \\
\text { motor-compressor } \\
\text { efficiencya }\end{array}$ & $\begin{array}{c}\text { Volumetric } \\
\text { efficiency }\end{array}$ \\
\hline$-4.5(22.9)$ & $2.61(8,900)$ & $0.030(235)$ & 4.6 & 0.44 & 0.56 \\
$-2.9(26.7)$ & $2.73(9,300)$ & $0.032(255)$ & 4.4 & 0.44 & 0.57 \\
$3.6(38.4)$ & $3.10(10,600)$ & $0.039(306)$ & 4.4 & 0.46 & 0.59 \\
$9.0(48.2)$ & $3.39(11,600)$ & $0.045(357)$ & 4.1 & 0.47 & 0.58 \\
$13.3(56.0)$ & $3.58(12,200)$ & $0.048(382)$ & 4.2 & 0.49 & 0.61 \\
\hline
\end{tabular}

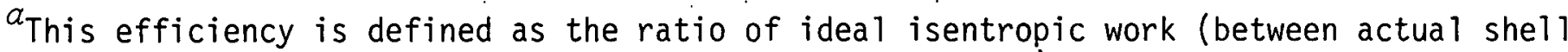
inlet conditions of the refrigerant and the discharge pressure) to the electrical power input to the compressor motor. 
The sixth column in Table 6.4 shows the volumetric efficiency of the compressor, based on the conditions of the refrigerant at the shell inlet. It varies from 0.56 to 0.61 and is calculated from the following expression:

$$
n_{v}=\frac{\dot{m}_{r e f}}{\rho_{s} D N}
$$

where

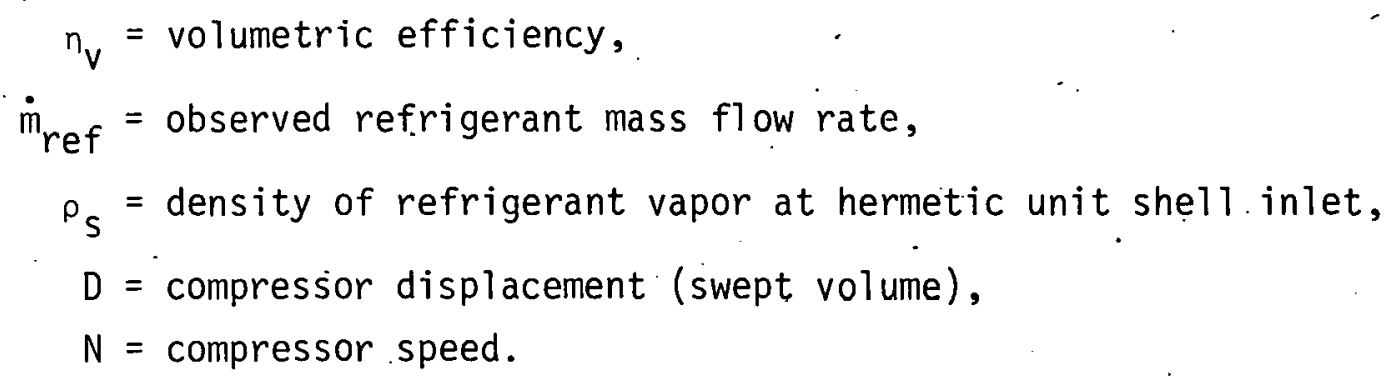


THIS PAGE

\section{WAS INTENTIONALLY LEFT BLANK}




\section{FROSTING-DEFROSTING TESTS}

\subsection{System Performance under Frosting Conditions}

Tests of the heat pump under conditions that allow for frost formation on the outdoor coil were conducted in order to evaluate degradation of performance parameters under these conditions, and to observe the response of the system to stresses so imposed. Tests were conducted at the outdoor. air temperatures and humidities shown previously in Table 2.3.

The performance parameters measured in each of the frosting tests include the heating capacity, COP, refrigerant pressures at high and low side of the system, the refrigerant mass flow rate, compressor and outdoor fan power consumption, the airflow rate through the outdoor coil, and the air pressure drop across the coil.

The airflow rates and pressure drops were, of course, measured with the outdoor unit in the testing loop and with the booster fan operating. As previously mentioned (Sect. 2.1) the flow rates and pressure drops were higher than would be expected for a unit operating in free air, but the deviation from rated airflow rates is not expected to cause more than a $5 \%$ change in any of the performance parameters, with the possible exception of the power consumed by the outdoor fan motor. Comparisons with similar tests where no booster fan was needed indicate that the variation of the outdoor fan motor power is not atypical.

\subsubsection{Test at $0.6^{\circ} \mathrm{C}\left(33^{\circ} \mathrm{F}\right)$ and $100 \%$ relative humidity}

- The test at $100 \%$ relative humidity subjected the heat pump to one of the more severe frosting conditions that it may encounter. The steam injector was placed in the airflow pattern upstream of the outdoor coil. At $100 \%$ relative humidity, the arrangement allowed fog to reach the coil. Under these conditions, frost formation was rapid and heavy enough to. require that the tests be terminated after $50 \mathrm{~min}$ because the airflow rate had dropped to less than $20 \%$ of its nominal value, accompanied by rapid decreases in the refrigerant pressures and flow rate, a condition that may not provide for proper cooling of the compressor motor. 
Figures 7.1 through 7.4 show the variation of the measured parameters as functions of time after the outdoor coil surface reaches $0^{\circ} \mathrm{C}\left(32^{\circ} \mathrm{F}\right)$. At the conclusion of the tests, the heating capacity and COP had fallen to $82 \%$ and $88 \%$ of their starting values (Fig. 7.1), a remarkably small decrease in view. of the drop in airflow rate to $16 \%$ of its original value (Fig. 7.2). Refrigerant pressures and flow rate decreased by amounts similar to those observed for the heating capacity and COP. The decreased refrigerant flow rate allows for a corresponding drop in power input to the compressor motor, while the rapidly increasing air pressure drop across the coil requires an increase in the power consumption rate of the outdoor fan.

\subsubsection{Tests at $0.6^{\circ} \mathrm{C}\left(33^{\circ} \mathrm{F}\right)$ and 92 to $97 \%$ relative humidity}

The severity of the frosting test at $100 \%$ relative humidity can be appreciated by comparison of the results of those tests with the tests at the same ambient dry bulb temperature but slightly lower relative humidity. The tests at 92 to $97 \%$ relative humidity revealed the same degradation of performance, but at an appreciably slower rate; comparisons of Figs. 7.5 through 7.8 with their counterparts, Figs: 7.1 through 7.4, show that the unit could run almost twice as long at the lesser humidity before the performance parameters had dropped to the levels observed at the conclusion of the more severe tests.

\section{1 .3 Tests at $-2.2^{\circ} \mathrm{C}\left(28^{\circ} \mathrm{F}\right)$ and 80 to $85 \%$ relative humidity}

Further reduction of the relative humidity, even though it was accompanied by a small drop in the dry bulb temperature, produced test results that are strikingly different from the results of the tests described above. After about 90 min of frosting operation all of the measured performance parameters, except the air pressure drop across the outdoor coil, were within $10 \%$ of their starting values. While the airside pressure drop had risen noticeably, the airflow rate had decreased on 1 y $3 \%$. As may be seen in Figs. 7.9 through 7.12 , none of the parameters had begun changing rapidly near the end of the tests as they had in the tests at higher humidities. 


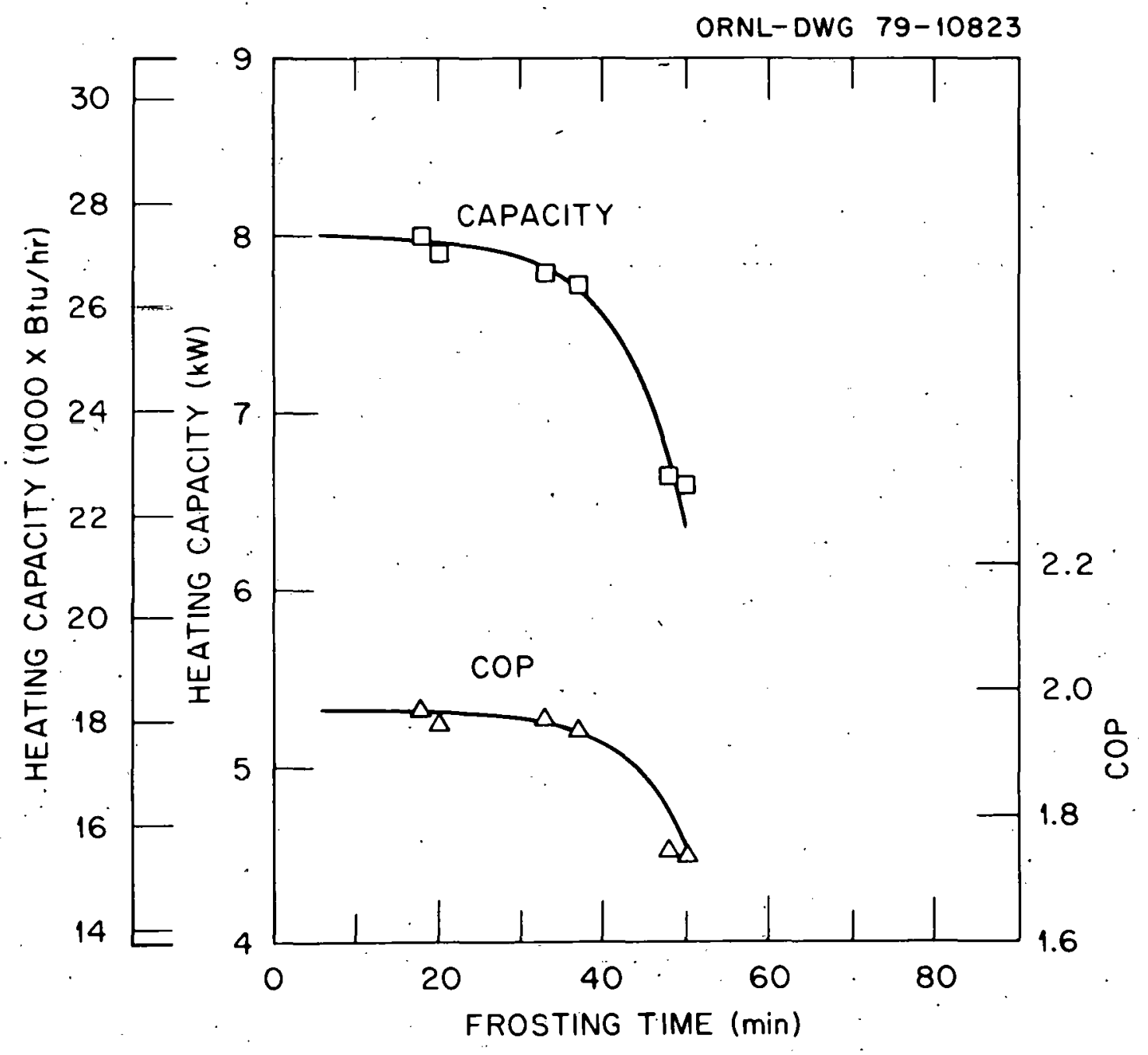

Fig. 7.1. Heating capacity and COP during a 50 min frosting period with outdoor air at $0.6^{\circ} \mathrm{C}$ and $100 \%$ relative humidity. 


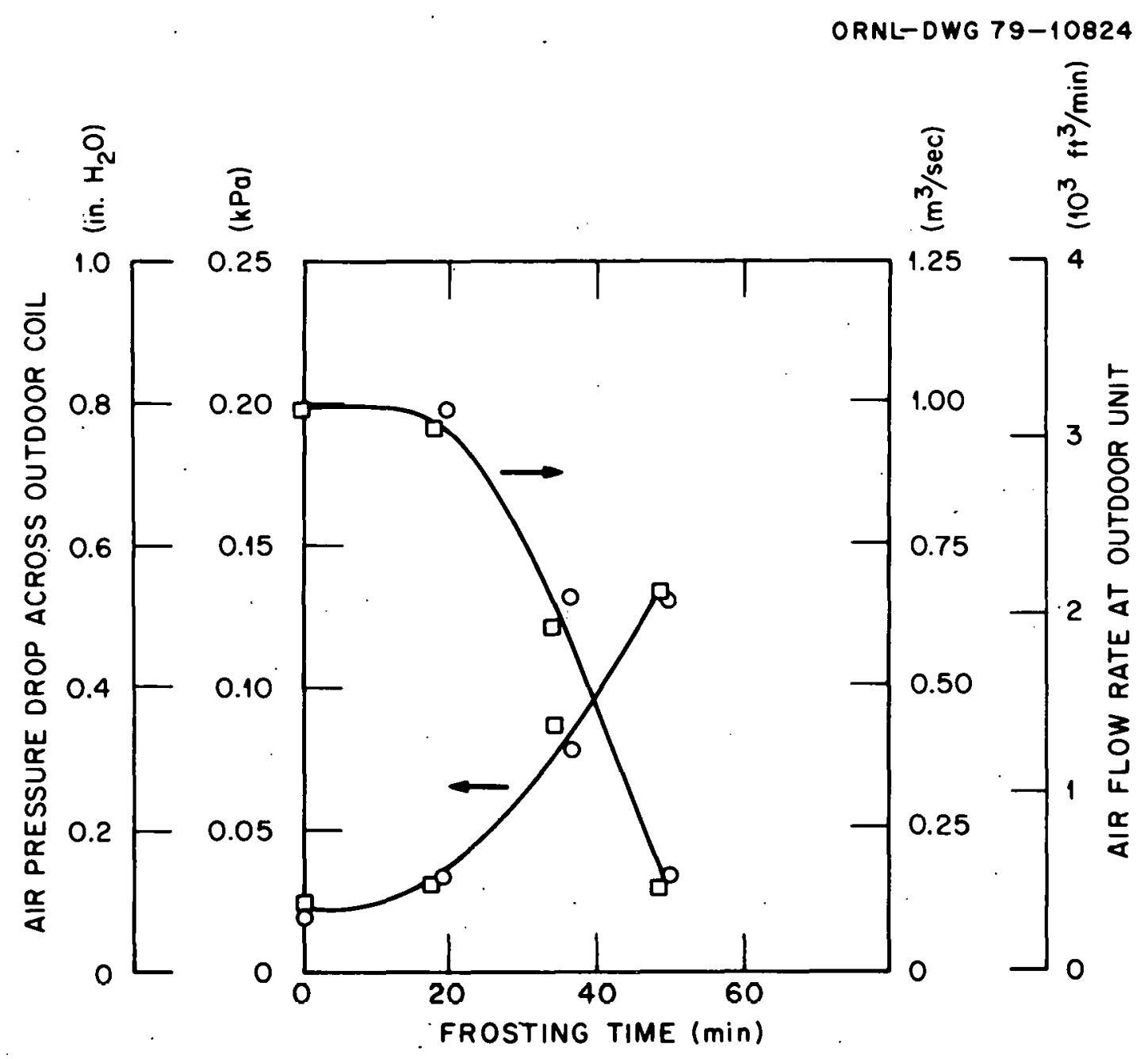

Fig. 7.2. Outdoor-coil air pressure drop and airflow rate during 50 min frosting period with outdoor air at $0.6^{\circ} \mathrm{C}$ and $100 \%$ relative humidity. 


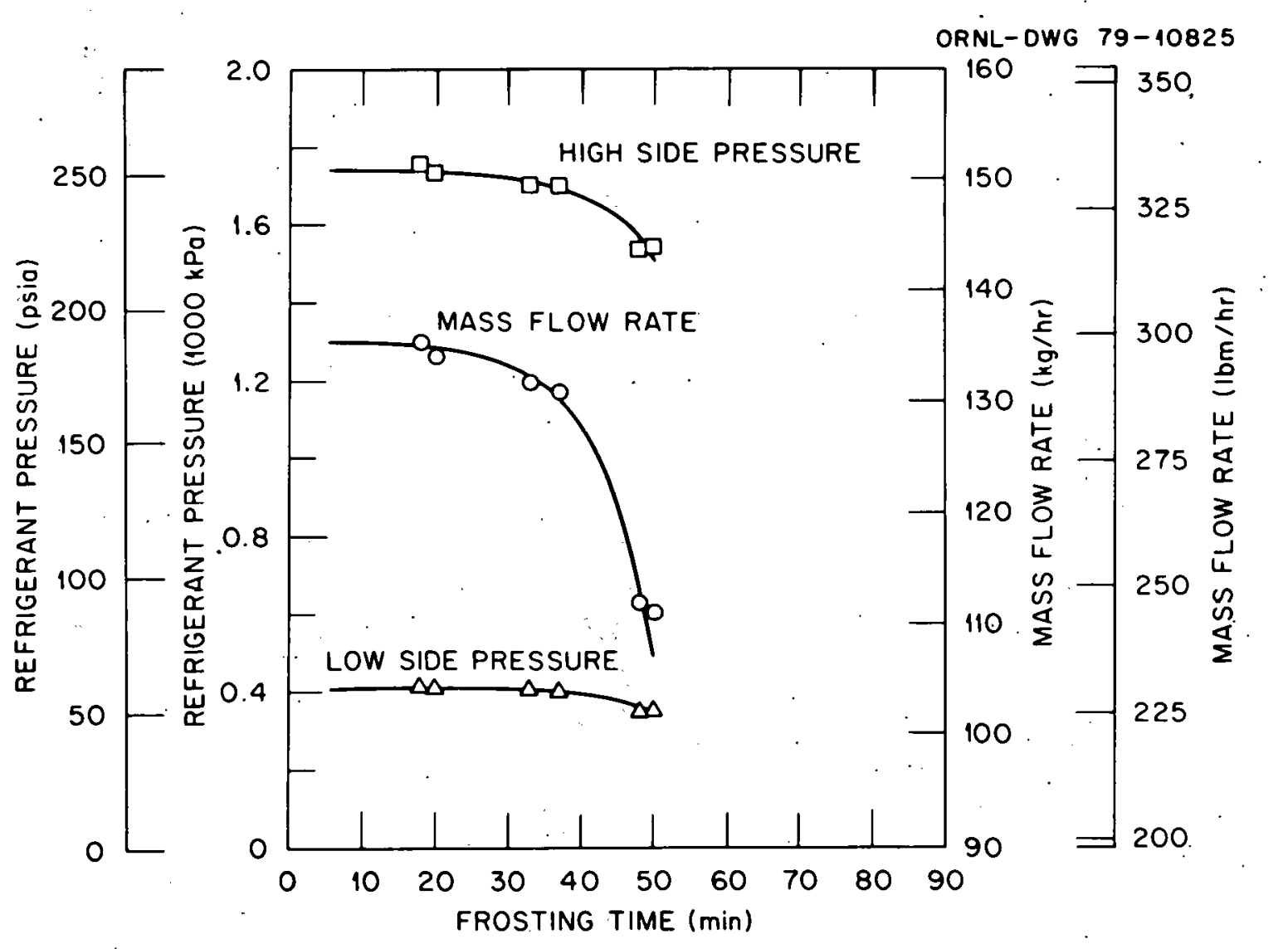

Fig. 7.3. Refrigerant pressures and flow-rates during a 50 min frosting period with outdoor air at $0.6^{\circ} \mathrm{C}$ and $100 \%$ relative humidity. 


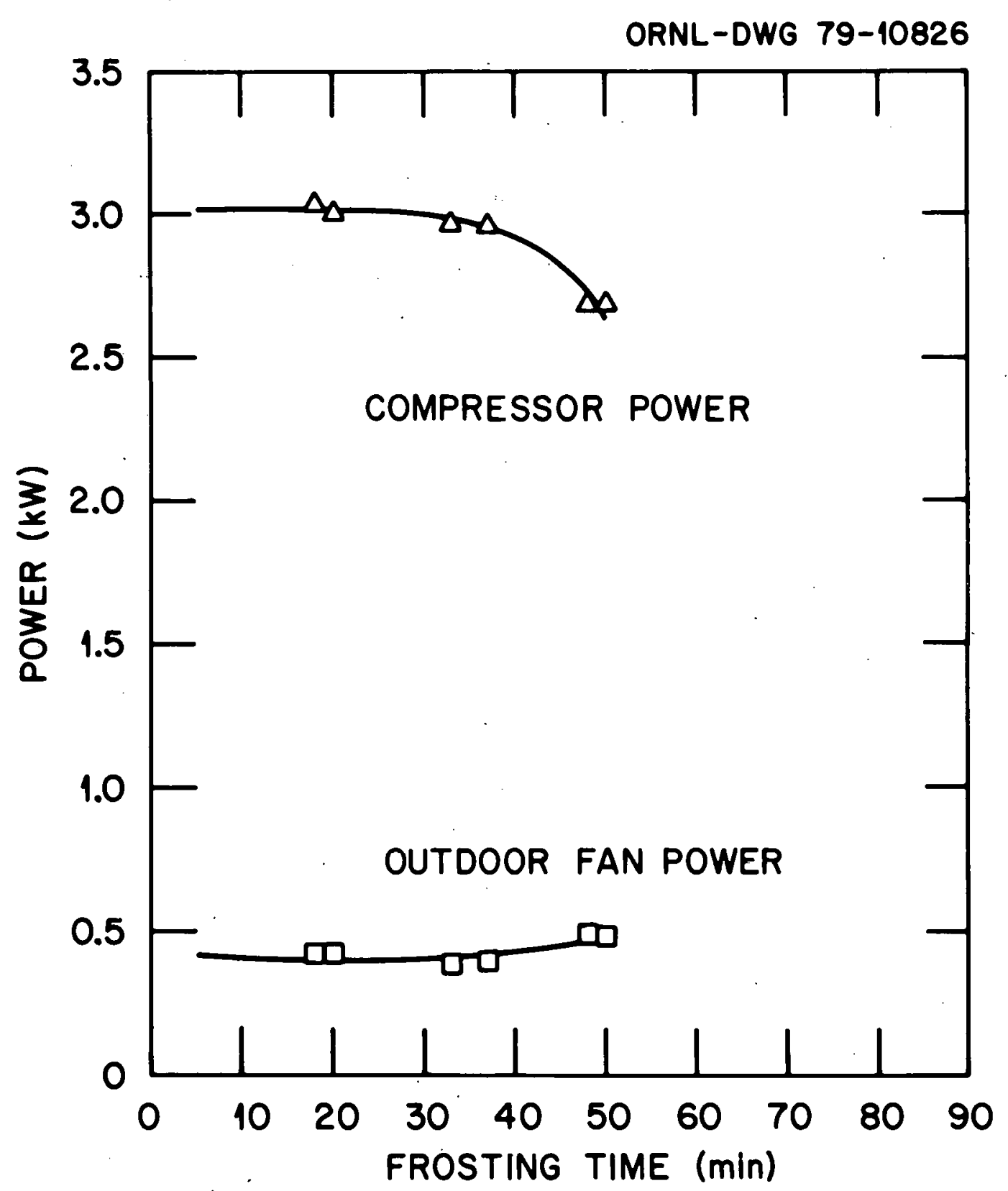

Fig. 7.4. Compressor and outdoor fan power consumption during a 50 min frosting period with outdoor air at $0.6^{\circ} \mathrm{C}$ and $100 \%$ relative humidity. 


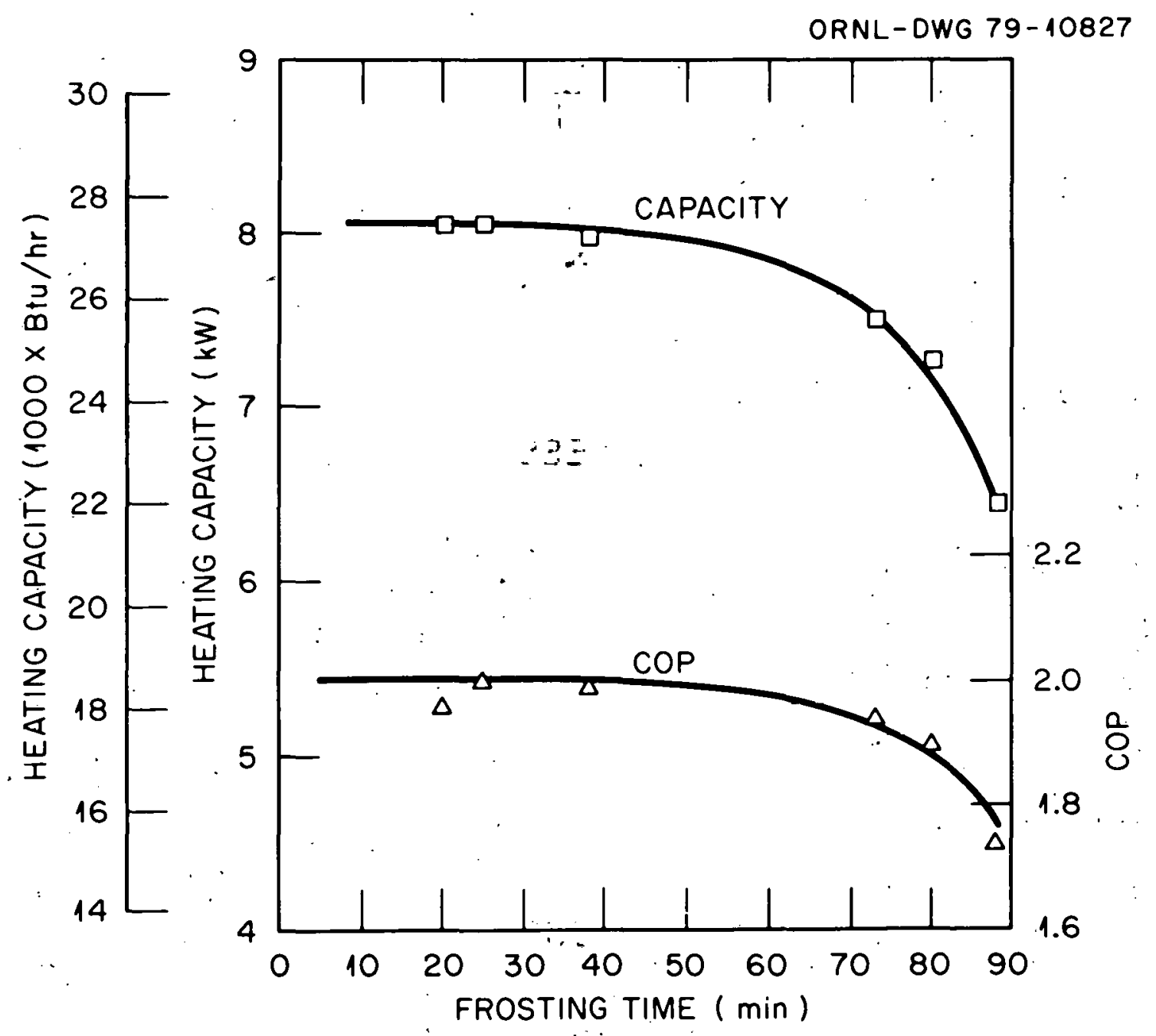

Fig. 7.5. Heating capacity and COP during a 90 min frosting period with outdoor air at $0.6^{\circ} \mathrm{C}$ and $92-97 \%$ relative humidity. 


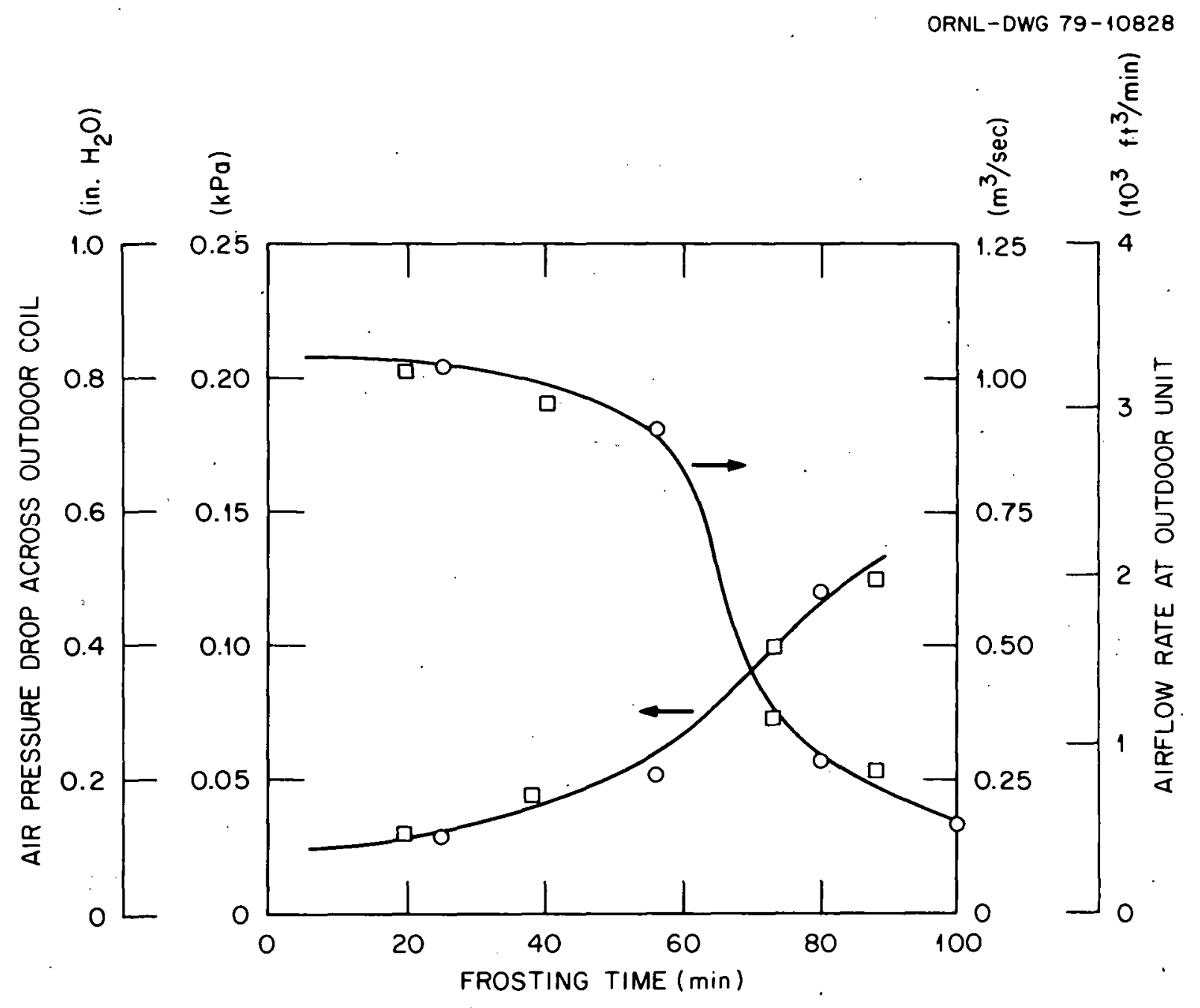

Fig. 7.6. Outdoor-coil air pressure drop and airflow rate during a 90 min frosting period with outdoor air at $0.6^{\circ} \mathrm{C}$ and $92-97 \%$ relative humidity. 


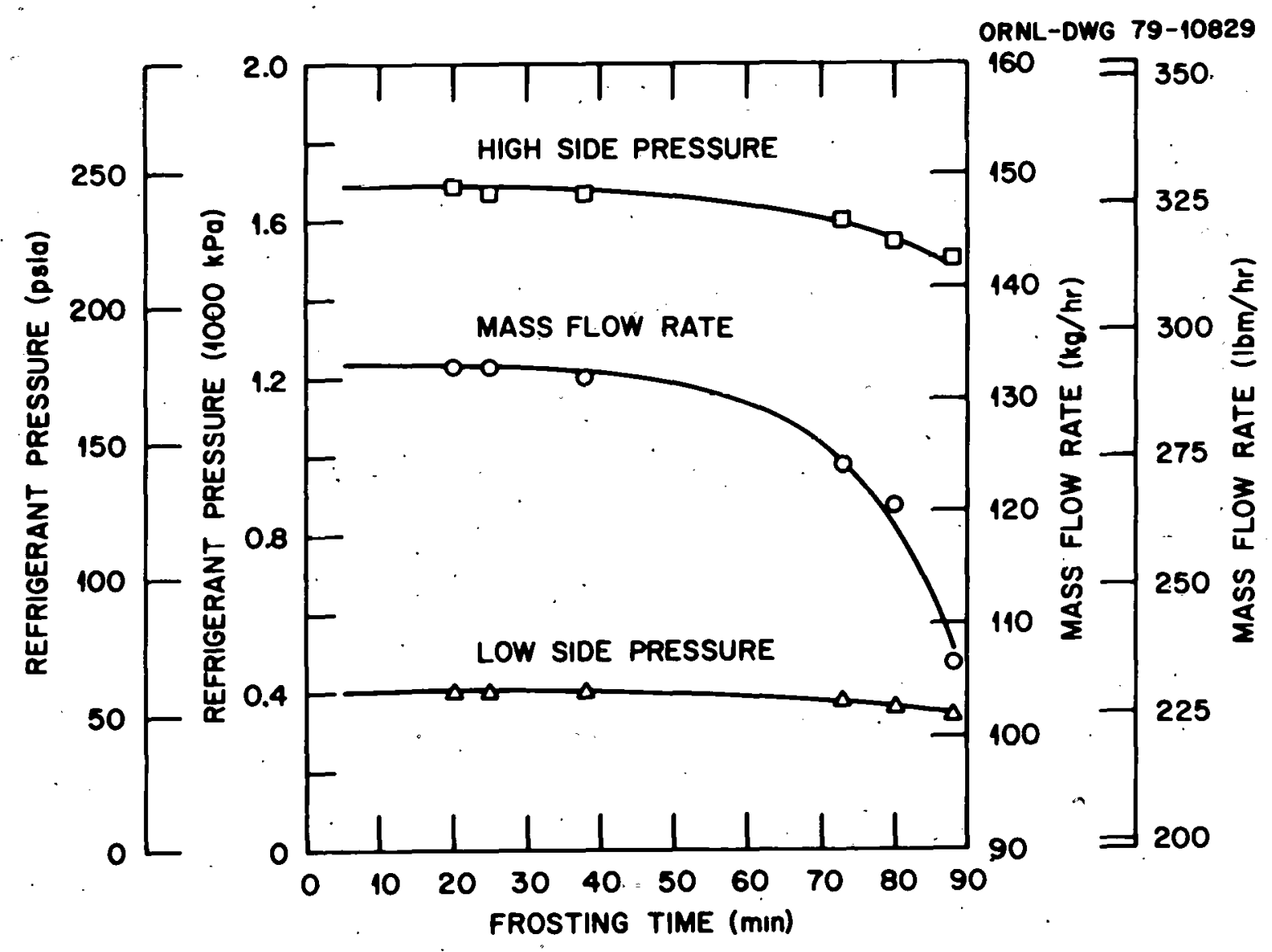

Fig. 7.7. Refrigerant pressures and flow rates during a 90 min frosting period with outdoor air at $0.6^{\circ} \mathrm{C}$ and $92-97 \%$ relative humidity. 


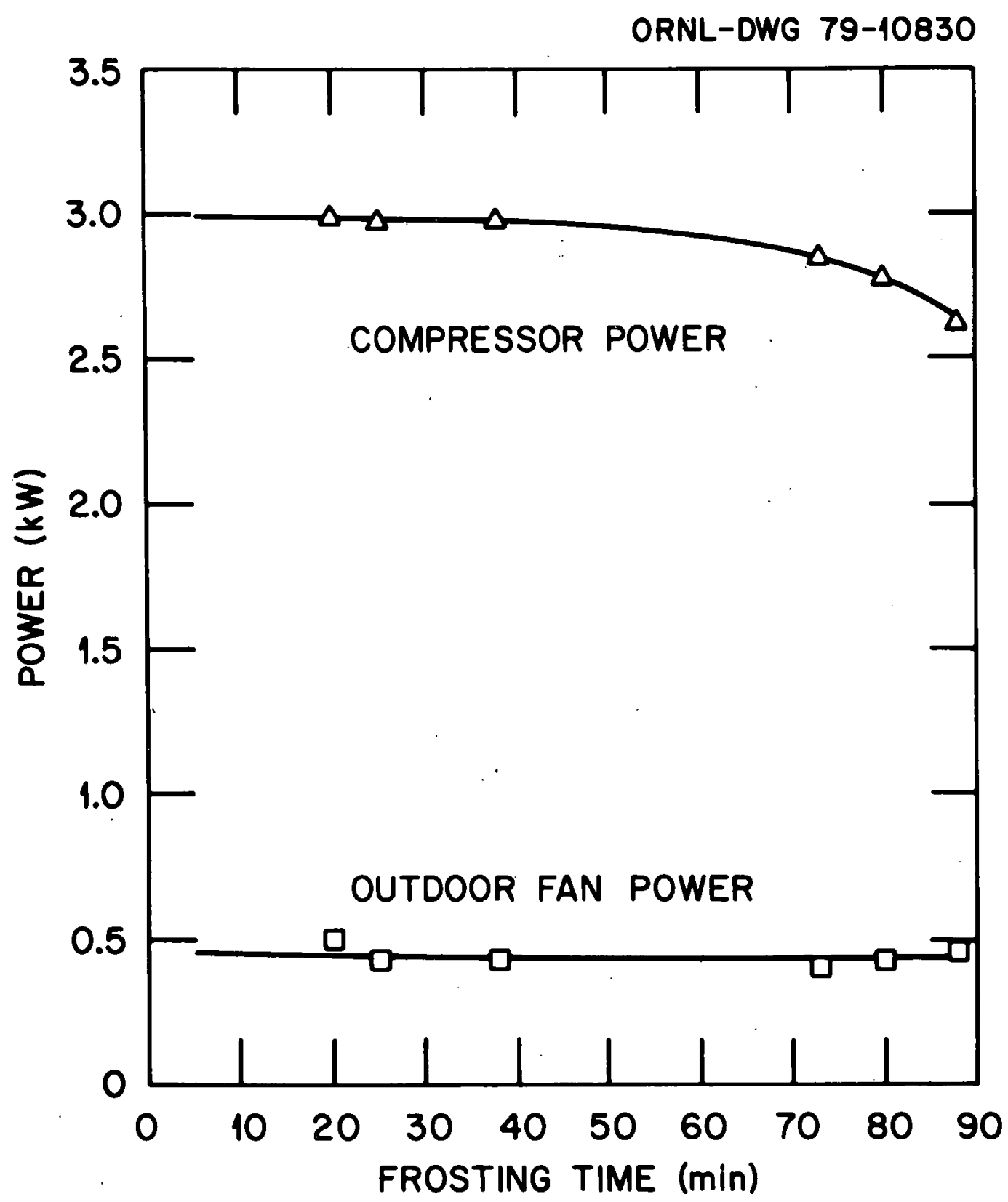

Fig. 7.8. Compressor and outdoor fan power consumption during a 90 min frosting period with outdoor air at $0.6^{\circ} \mathrm{C}$ and $92-97 \%$ relative humidity. 


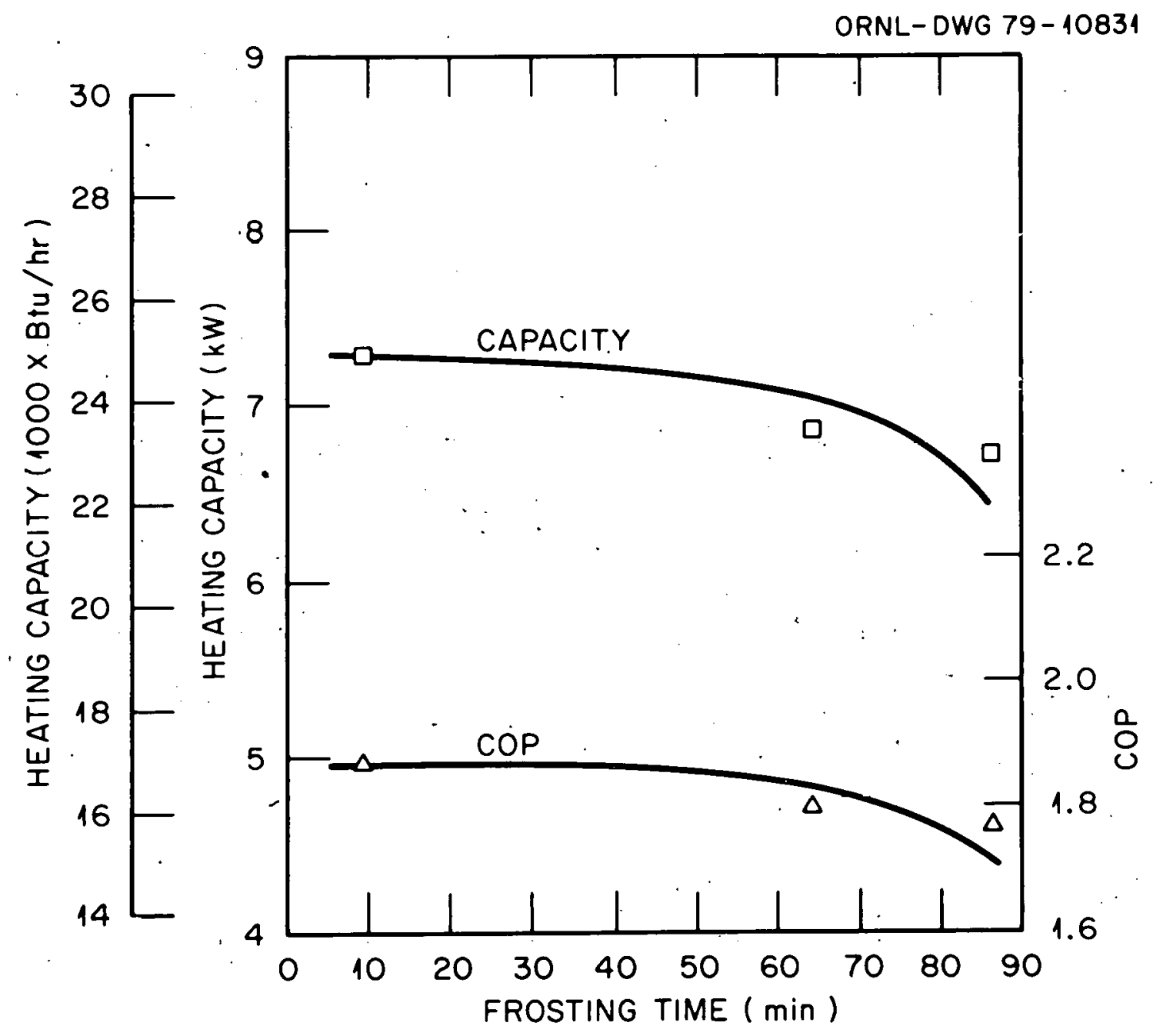

Fig. 7.9. Heating capacity and COP during a 90 min frosting period with outdoor air at $-2.2^{\circ} \mathrm{C}$ and $80-85 \%$ relative humidity. 


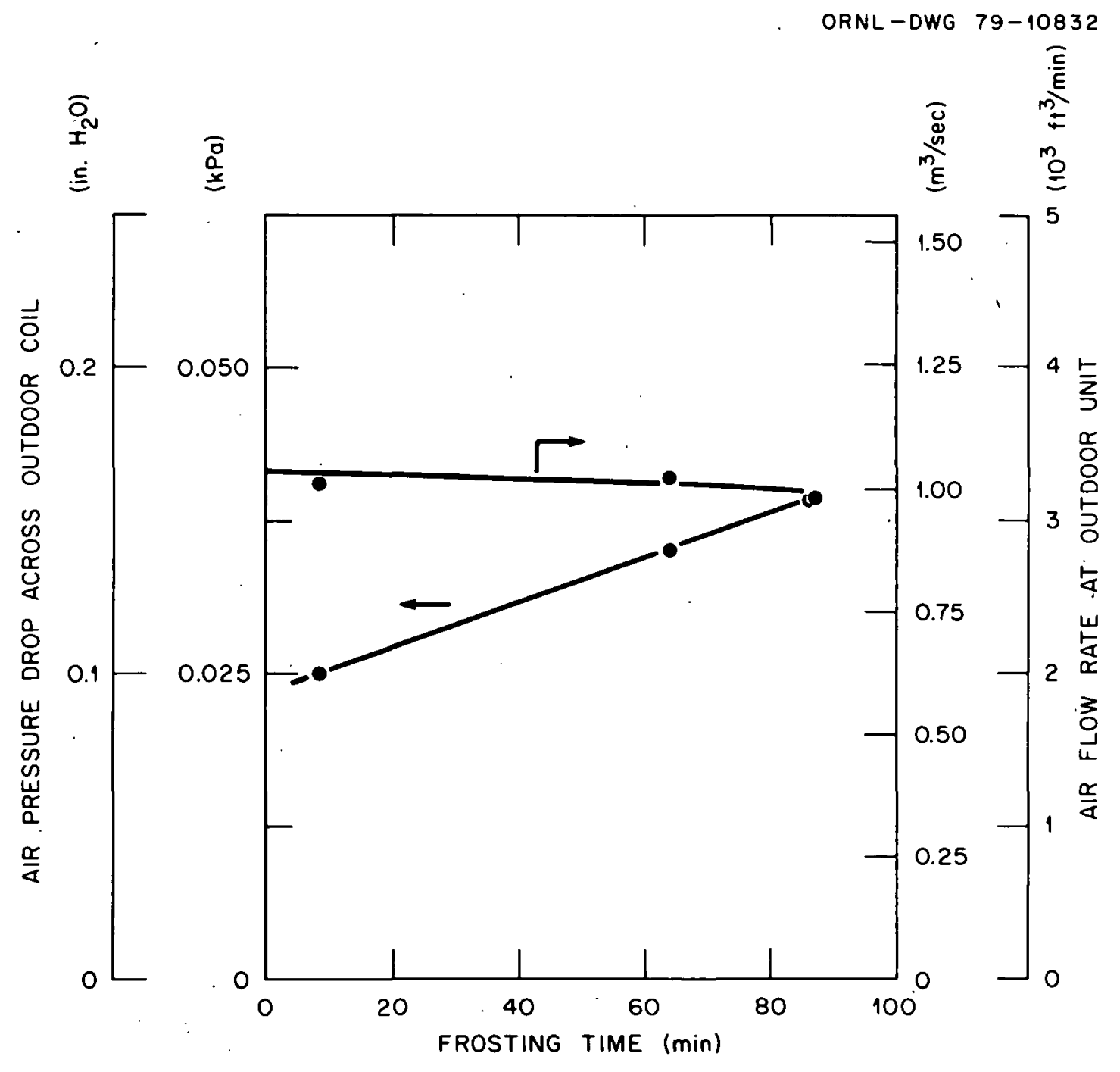

Fig. 7.10. Outdoor-coil air pressure drop and airflow rate during a 90 min frosting period with outdoor air at $-2.2^{\circ} \mathrm{C}$ and $80-85 \%$ relative humidity. 


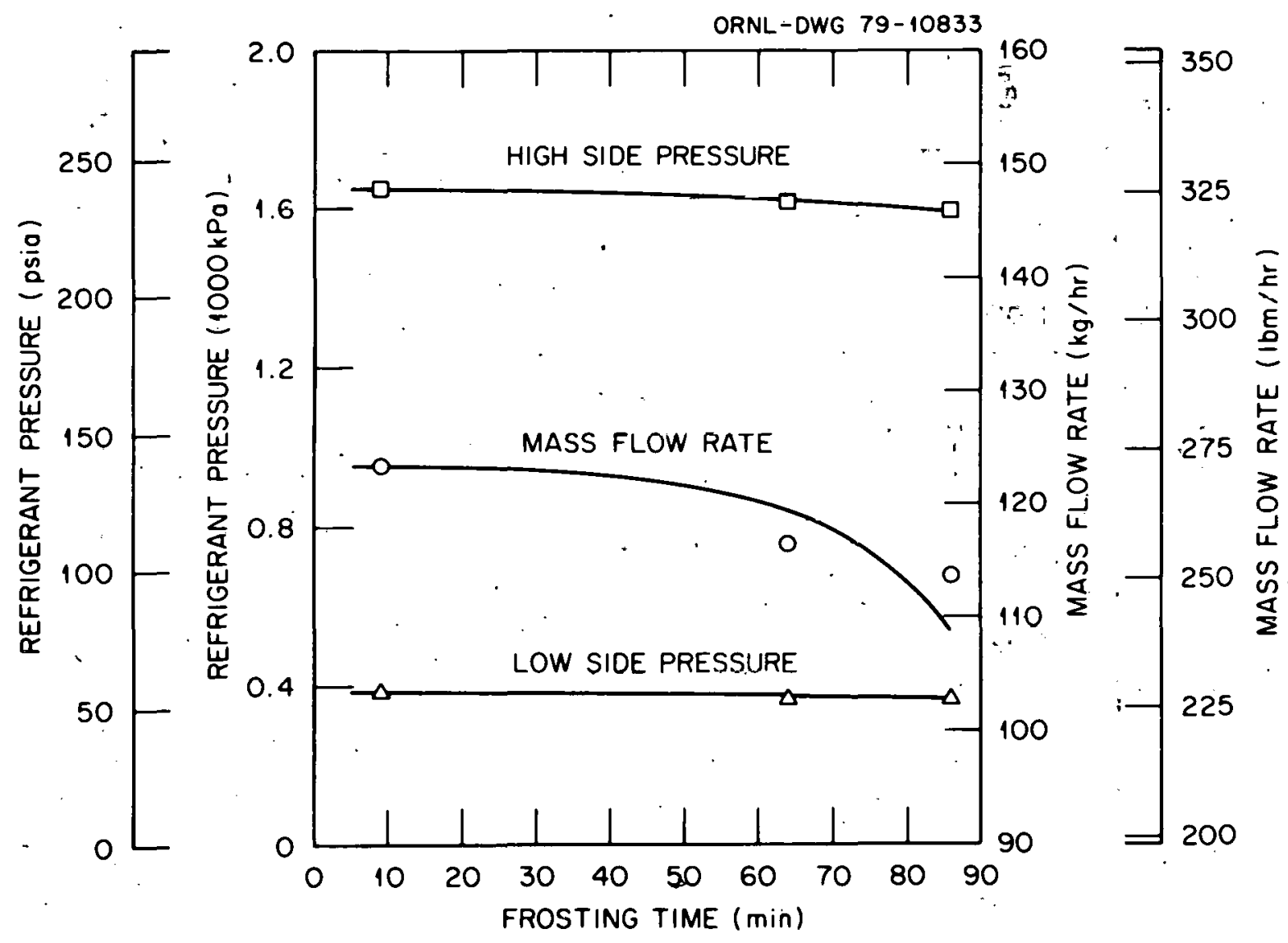

Fig. 7.11. Refrigerant pressures and flow rates during a 90 min frosting period with outdoor air at $-2.2^{\circ} \mathrm{C}$ and $80-85 \%$ relative humidity. 


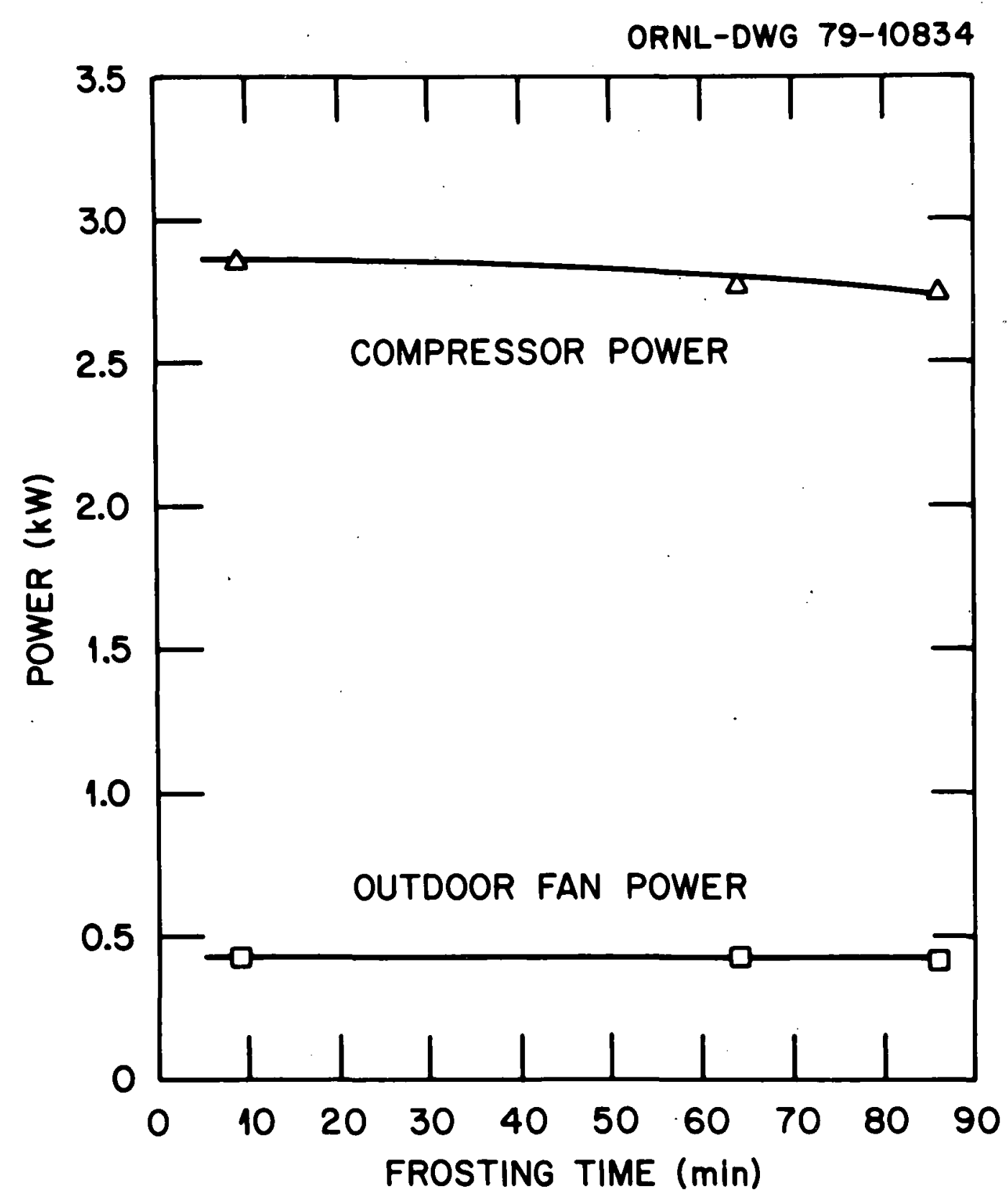

Fig. 7.12. Compressor and outdoor fan power consumption during a 90 min frosting period with outdoor air at $-2.2^{\circ} \mathrm{C}$ and $80-85 \%$ relative humidity. 


\subsubsection{Defrost water collection}

After the operation of the heat pump under frosting-defrosting conditions, an indication of the amount of frost accumulated on the heat exchanger surfaces was obtained by measuring the amount of water discharged by the system drain. This is an approximate method because it does not account for the water that remains on the heat exchanger surfaces and in the sheet metal tray that forms the bottom of the outdoor unit. Table 7.1 shows the data for the defrost water measured. It is apparent that some of the water formed during the first defrosting period remains on the coil or in the tray, as indicated by the greater amounts of water collected after subsequent defrosting periods.

Table 7.1. Frost accumulation as evaluated by defrost water drain collection

\begin{tabular}{cccc}
\hline $\begin{array}{c}\text { Outdoor air } \\
\text { temperature } \\
{\left[{ }^{\circ} \mathrm{C}\left({ }^{\circ} \mathrm{F}\right)\right]}\end{array}$ & $\begin{array}{c}\text { Relative } \\
\text { humidity } \\
(\%)\end{array}$ & $\begin{array}{c}\text { Approximate } \\
\text { frosting period } \\
(\mathrm{min})\end{array}$ & $\begin{array}{c}\text { Water } \\
\text { collected } \\
(\mathrm{m} 1)\end{array}$ \\
\hline $0.6(33)$ & 100 & 50 & $\begin{array}{l}1100 \text { first defrost } \\
1300 \text { second defrost }\end{array}$ \\
$0.6(33)$ & $92-97$ & 90 & $\begin{array}{l}2800 \text { first defrost } \\
3200 \text { second defrost }\end{array}$ \\
& $\cdot$ & 9 & 1750 \\
\hline
\end{tabular}

\subsection{Compressor Performance during the Defrosting Period}

During the defrosting period, the high- and low-side refrigerant pressures and the power input to the compressor motor were recorded as functions of time after the initiation of the defrosting operation. The outdoor fan is turned off during this period, and the power consumed by the indoor fan motor is expected to remain at a constant value. The transducer used to recurd the low-side pressure was placed in the suction line, between the accumulator and the inlet to the compressor, and thus between the reversing valve and the compressor; the signal it sends to the strip chart recorder always represents the lowest pressure in the system regardless of the position of the reversing valve. The transducer 
used to record high-side pressure is in the liquid line that connects the two heat exchangers and thus records the pressure just upstream of the flow control device for either mode of operation.

Figure 7.13 shows the recorded pressure and compressor motor input power at the end of the 50-min frosting period and the subsequent defrosting period for the tests with $0.6^{\circ} \mathrm{C}\left(33^{\circ} \mathrm{F}\right)$ outdoor air temperature and $100 \%$ relative humidity. Figure 7.14 shows the corresponding interval for the 90 -min tests at $0.6^{\circ} \mathrm{C}\left(33^{\circ} \mathrm{F}\right)$ and 92 to $97 \%$ relative humidity; Figure 7.15 is for the tests at $-2.2^{\circ} \mathrm{C}\left(28^{\circ} \mathrm{F}\right), 80$ to $85 \%$ relative humidity.

As might be expected, the defrosting interval was longer for the more severe frosting conditions, lasting about $3.6 \mathrm{~min}$ following the frosting interval at $100 \%$ relative humidity, and decreasing to 2.75 min following the frosting tests at 80 to $85 \%$ relative humidity. The excursions of the recorded variables are seen to be similar for all three of the defrosting intervals.

Before the start of the defrosting operation, the indoor coil, which has been acting as the condenser, is filled in part by liquid refrigerant; partly by two-phase refrigerant. (There is very little superheating of the refrigerant in the suction line due to presence of liquid refrigerant in the suction-line accumulator.) At the start of the defrosting period, the reversing valve connects the discharge line of the compressor to the outdoor coil and the suction line (which contains the accumulator) to the end of the indoor coil that contains superheated vapor. The rapid rise in the low-side pressure during the first few seconds of the defrosting period results from the rapid transfer of superheated and two-phase refrigerant from the indoor coil (which is initially at high-side pressure) via an unrestricted path to the suction port of the compressor. This rapid movement of refrigerant is reflected also in the sudden drop in high-side pressure observed in Fig. 7.14.

After the initial rapidfluctuations, both high- and low-side pressures decrease as the indoor coil is emptied of "liquid refrigerant and the refrigerant condenses in the s.till cold and heavily frosted outdoor coil. The high-șide pressure begins to rise after 30 to $45 \mathrm{sec}$ of defrosting operation as the heated refrigerant begins to warm the outdoor coil. The 
ORNL-DWG 79-10835
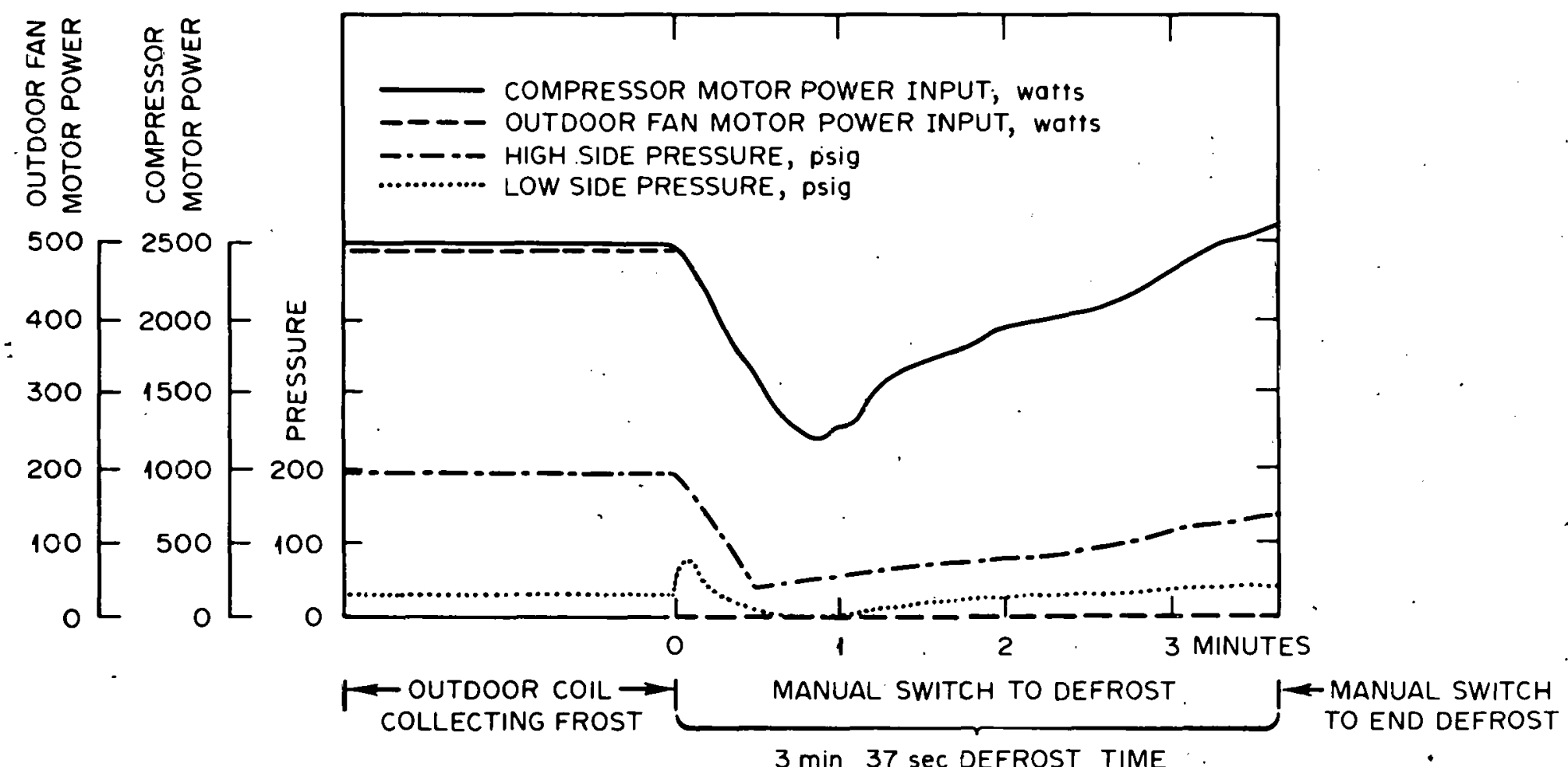

$3 \mathrm{~min} 37 \mathrm{sec}$ DEFROST TIME

Fig. 7.13. Power consumption and system pressures during a defrosting period following a 50 min frosting interval with the outdoor air at $0.6^{\circ} \mathrm{C}$ and $100 \%$ relative humidity. 
ORNL-DWG 79-10836

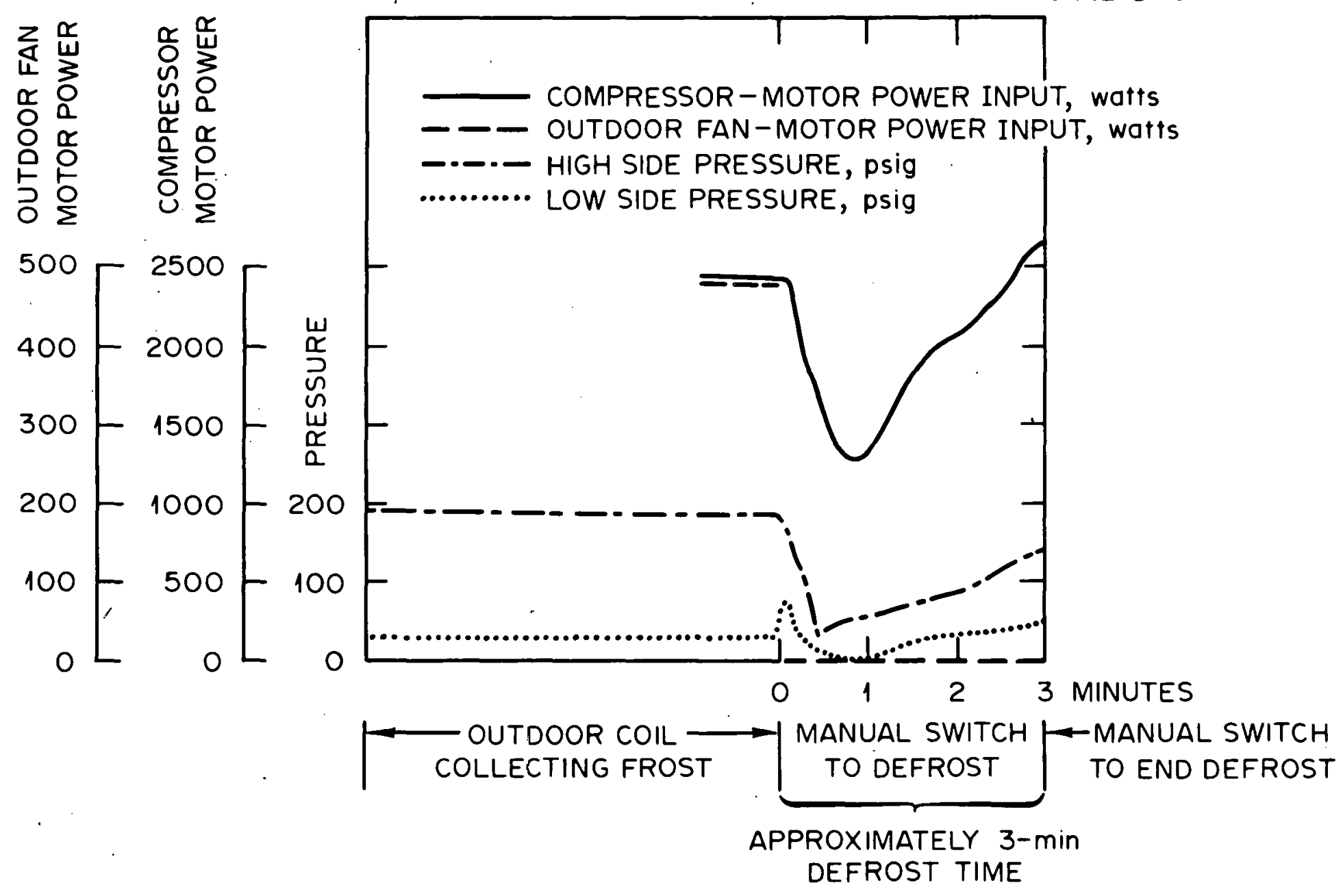

Fig. 7.14. Power consumption and system pressures during a defrosting period following a 90 min frosting interval with the outdoor air at $0.6^{\circ} \mathrm{C}$ and $92-97 \%$ relative humidity. 


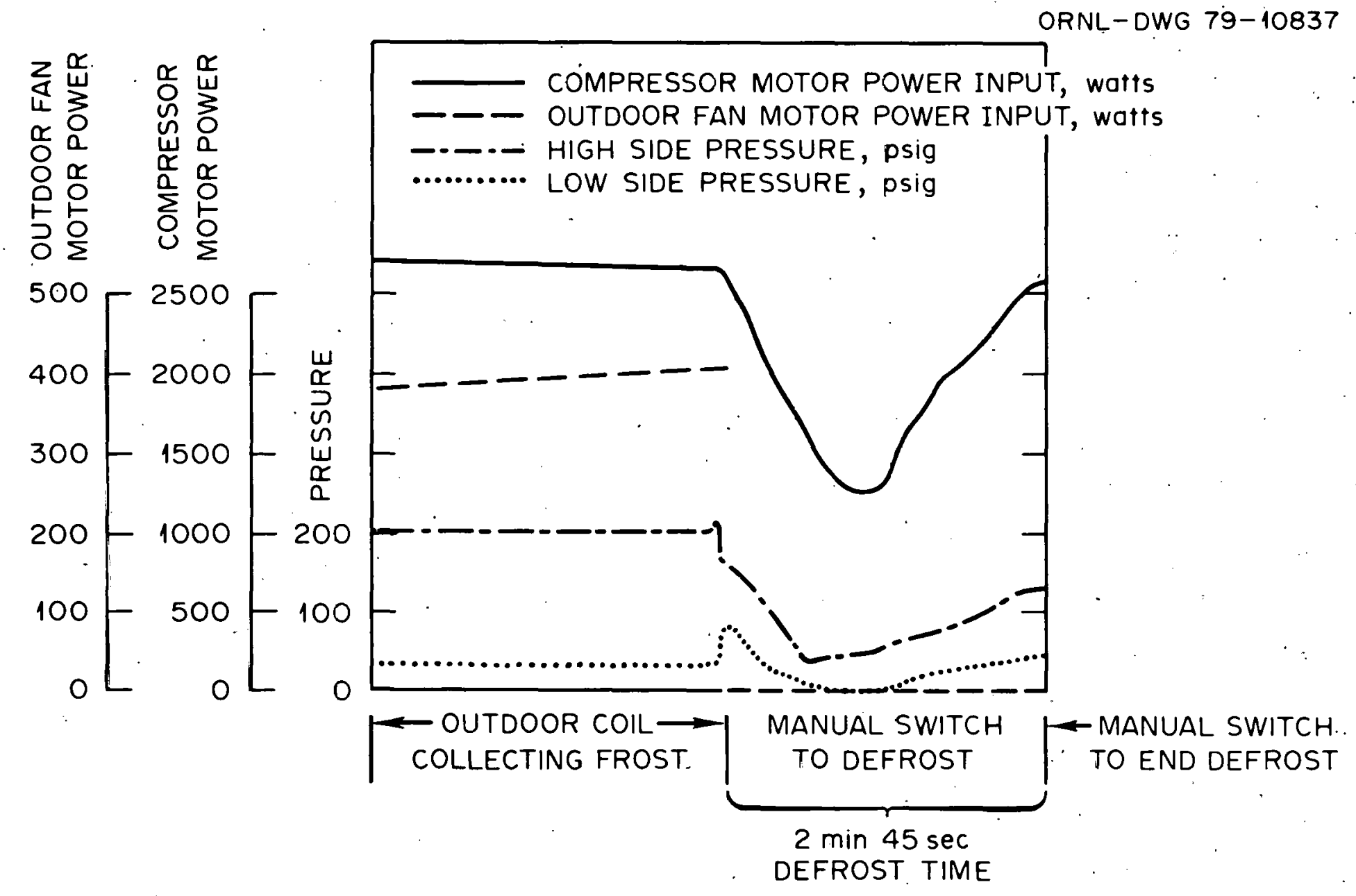

Fig. 7.15. Power consumption and system pressures during a defrosting period following a 90 min frosting interval with the outdoor air at $-2.2^{\circ} \mathrm{C}$, and $80-85 \%$ relative humidity. 
rise in the low-side pressure does not start until the high-side pressure has recovered enough to start passing refrigerant through the flow control device in the line between the outdoor and indoor coils. At this point in the defrosting operation, normal operation of the vapor compression cycle resumes, except that the outdoor fan is still t turned off. Consequently, the pressures begin to $r i s e$, and would reach an overload condition were the defrosting operation not halted. A temperature sensor on the outdoor coil signals the end of the defrost period when the coil reaches about $18^{\circ} \mathrm{C}\left(65^{\circ} \mathrm{F}\right)$, which occurs well before dangerous operating conditions are reached. Compressor power follows the low-side pressure during the defrosting interval.

At the conclusion of the defrosting operation, the reversing valve switches the compressor discharge to the inlet of the indoor coil, and the outlet of the outdoor coil to the suction line. The resulting perturbations last about one minute. 


\section{REFRIGERANT CHARGE VARIATION TESTS}

A11 of the tests reported in the preceding sections of this report were conducted with the heat pump charged with the amount of refrigerant specified by the manufacturer. In operation, the charge may be reduced by leaks in the system. Attempts to compensate for lost refrigerant after the repair of leaks may result in excess charge. The low-firstcost heat pump previously tested, ${ }^{1}$ which lacks a suction-line accumulator, was found to be highly sensitive to charge, whereas the efficiency of the heat pump selected for these tests remains essentially constant when the actual charge is within about $20 \%$ of the rated charge of $2.86 \mathrm{~kg}$ (6 $1 \mathrm{~b}, 5 \mathrm{oz})$.

Tests were conducted with the heat pump operating in the heating mode at an outdoor air temperature of $10^{\circ} \mathrm{C}\left(50^{\circ} \mathrm{F}\right)$ and indoor air temperature of $21^{\circ} \mathrm{C}\left(70^{\circ} \mathrm{F}\right)$. The amount of refrigerant in the circuit was varied from $i .81 \mathrm{~kg}(4 \mathrm{lb})$ to $3.63 \mathrm{~kg}(8 \mathrm{lb})$.

As was previously noted in the steady-state tests, the suction-line superheat remained very low at all outdoor air temperatures. This effect was attributed to the presence of liquid refrigerant in the suction-line accumulator when the system is properly charged with refrigerant. As shown in Fig. 8.1, the suction- 7 ine superheat remains at or near $0 \mathrm{C}^{\circ}$ $\left(0 \mathrm{~F}^{\circ}\right)$ until the charge is reduced to about $2.72 \mathrm{~kg}(6 \mathrm{lb})$. Further reduction of the refrigerant charge results in substantial increase of. the superheat. The suction-line superheat remains at approximately zero when the unit is overcharged since there is an ample supply of liquid refrigerant in the accumulator. Refrigerant pressures are seen (Fig. 8.2) to remain nearly constant in the overcharge range, and to drop as the superheat increases in the undercharge range.

As a result of the lowered suction line pressure and increased superheat in the undercharged condition, refrigerant mass flow rates decrease rapidly (Fig. 8.3) when the charge is reduced below the value of $2.72 \mathrm{~kg}(6 \mathrm{lb})$, at which point the superheat begins to rise. A consequence of the reduced mass flow rate is the reduction of the heating capacity, which is the product of the mass flow rate and the change 
ORNL-DWG 79-10838

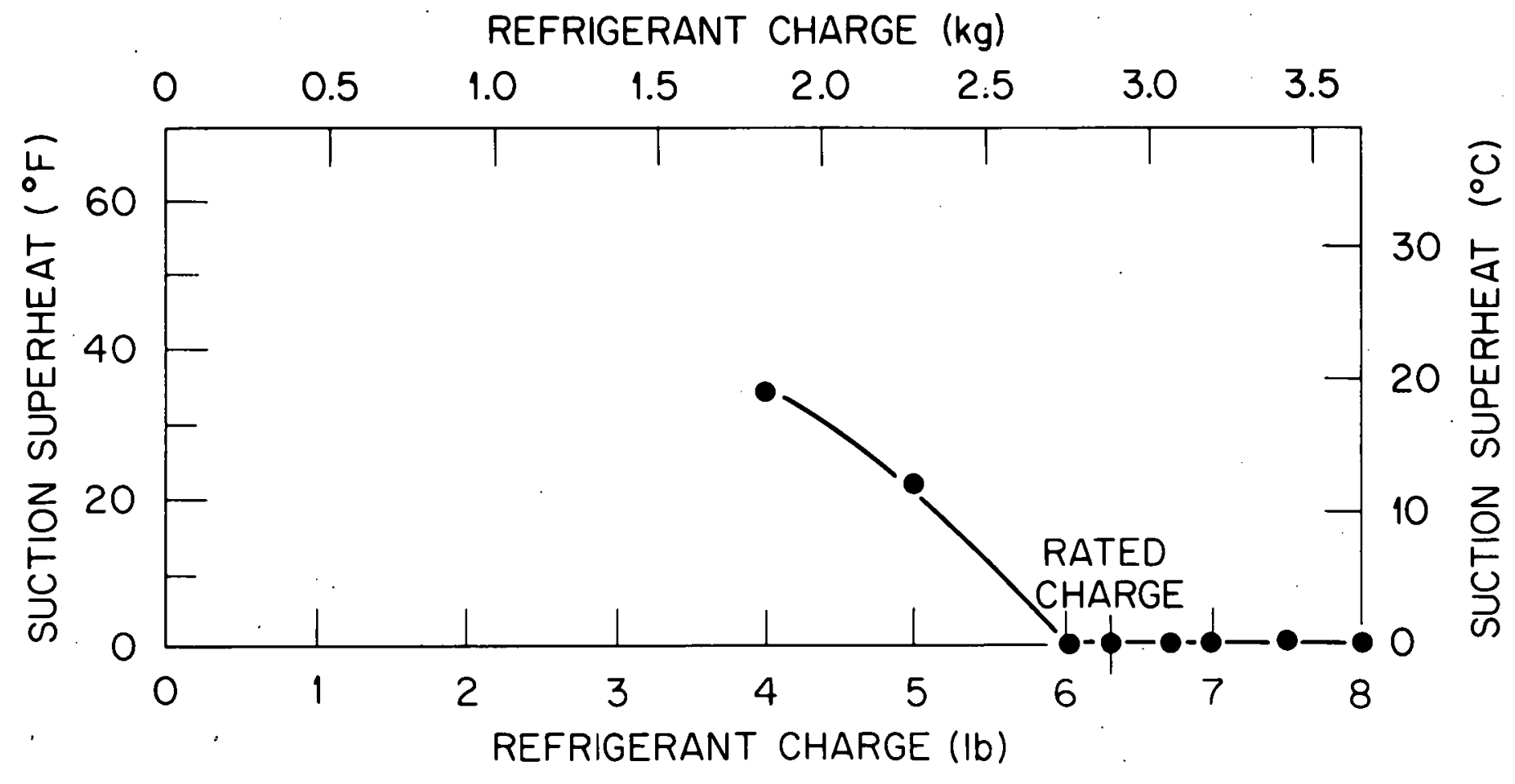

Fig. 8.1. Suction gas superheat as a function of refrigerant charge. 
ORNL-DWG 79-10839

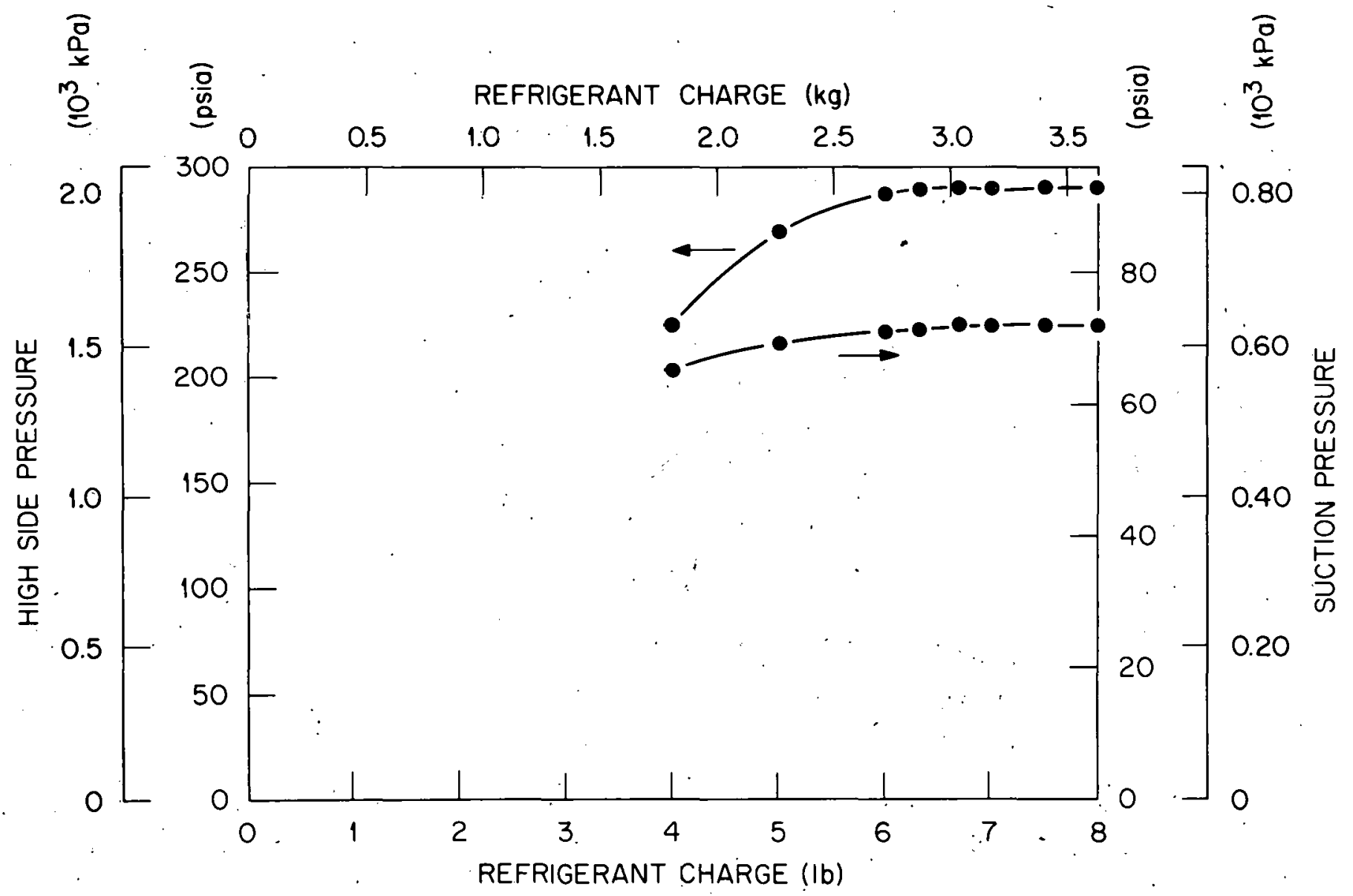

Fig. 8.2. System pressures as a function of refrigerant charge. 
ORNL-DWG $79-10840$

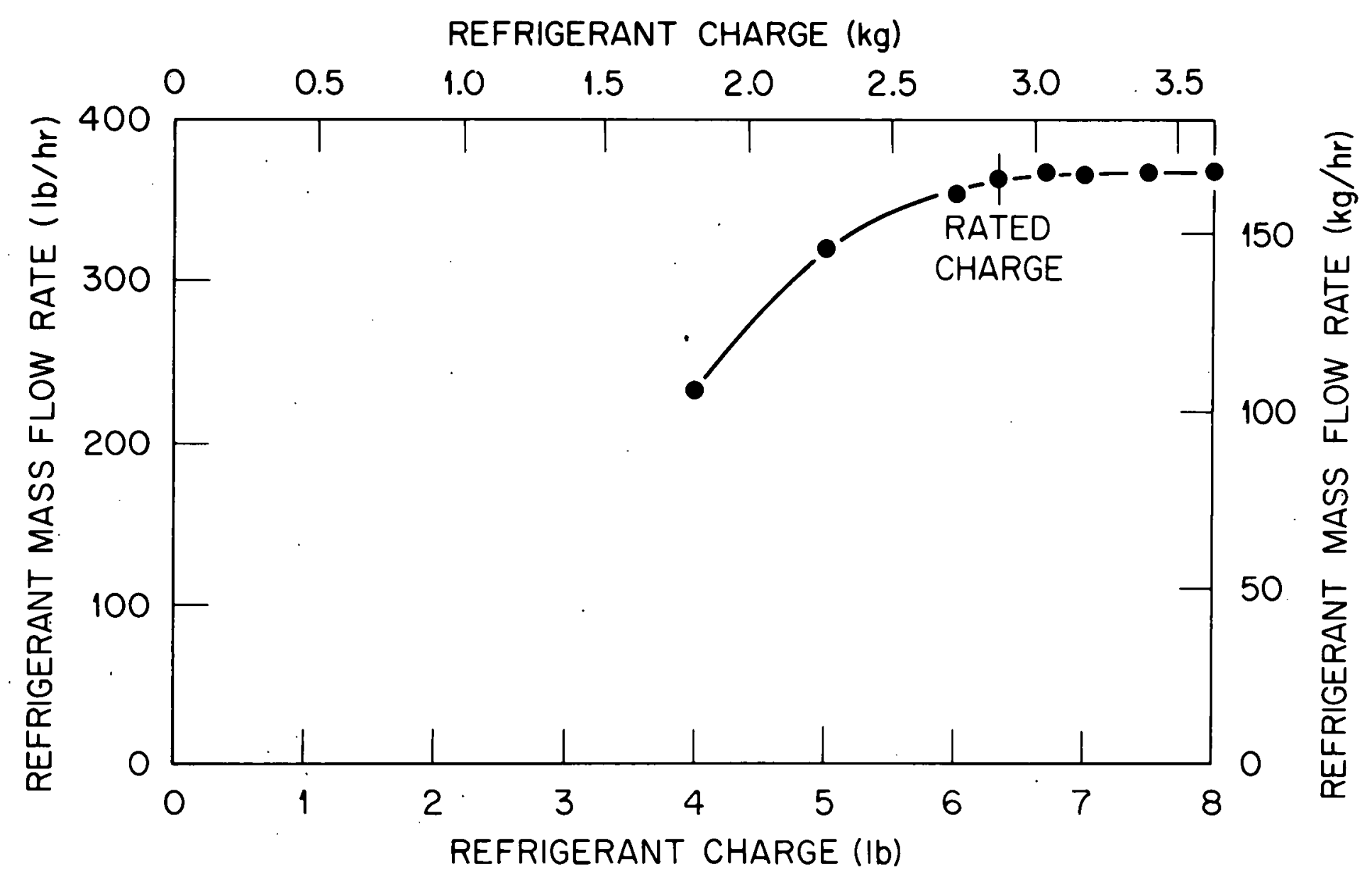

Fig. 8.3. Mass flow rate of refrigerant as a function of refrigerant charge. 
in enthalpy. The variation of heating capacity with charge is shown in 'Fig. 8.4. As would be expected, the mass flow rate and heating capacity remain at the values found for a properly charged system when the system is overcharged. The curve for the COP as a function of charge, shown in Fig. 8.5, is essentially flat in the overcharge range and drops off in the undercharge range, but less steeply. than do those for heating capacity and refrigerant mass flow rate. The COP of the previously tested low-first-cost unit ${ }^{1}$ as a function of charge is shown in the same graph for comparison. 


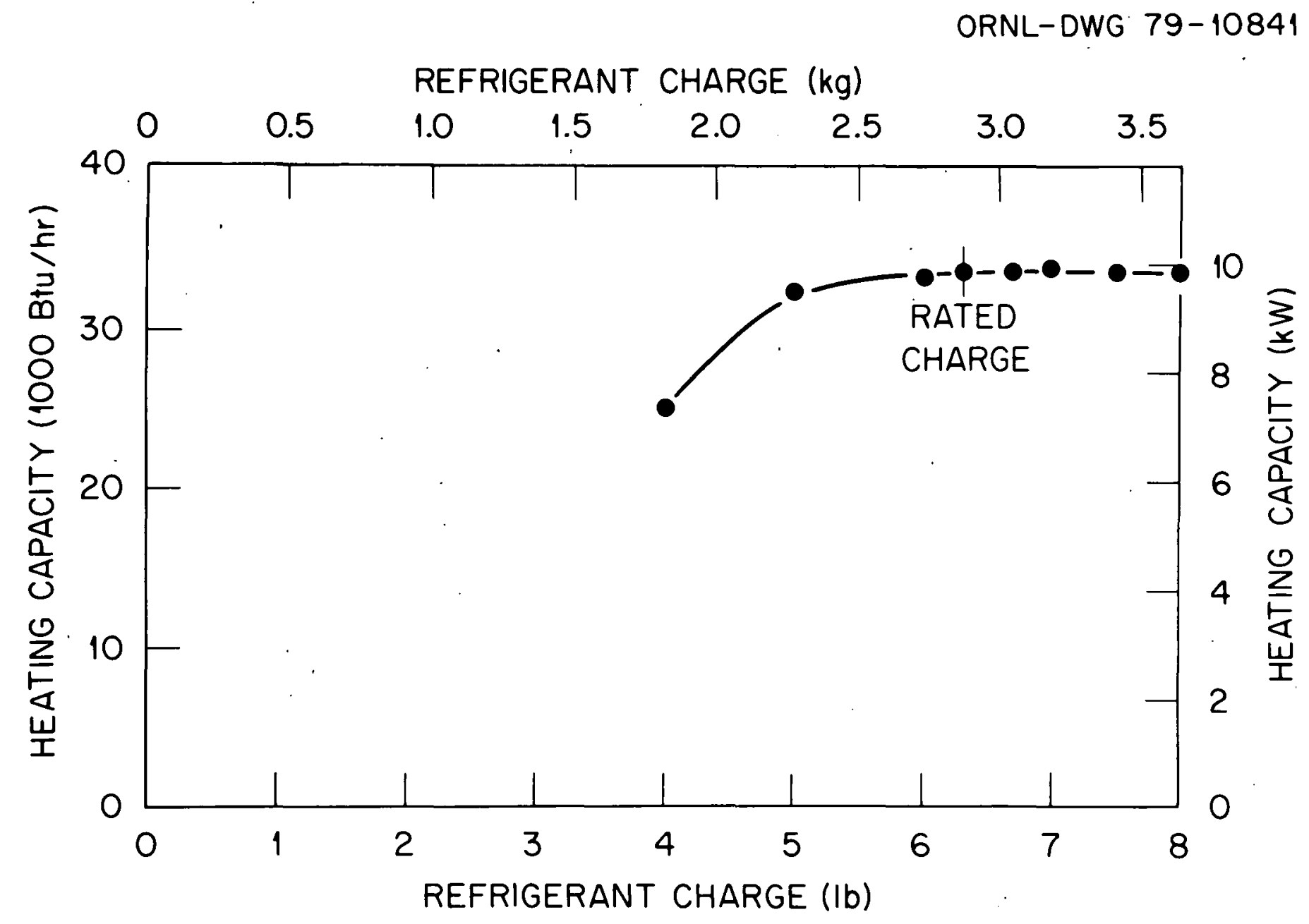

Fig. 8.4. Heating capacity as a function of refrigerant charge. 
ORNL-DWG 79-10842R

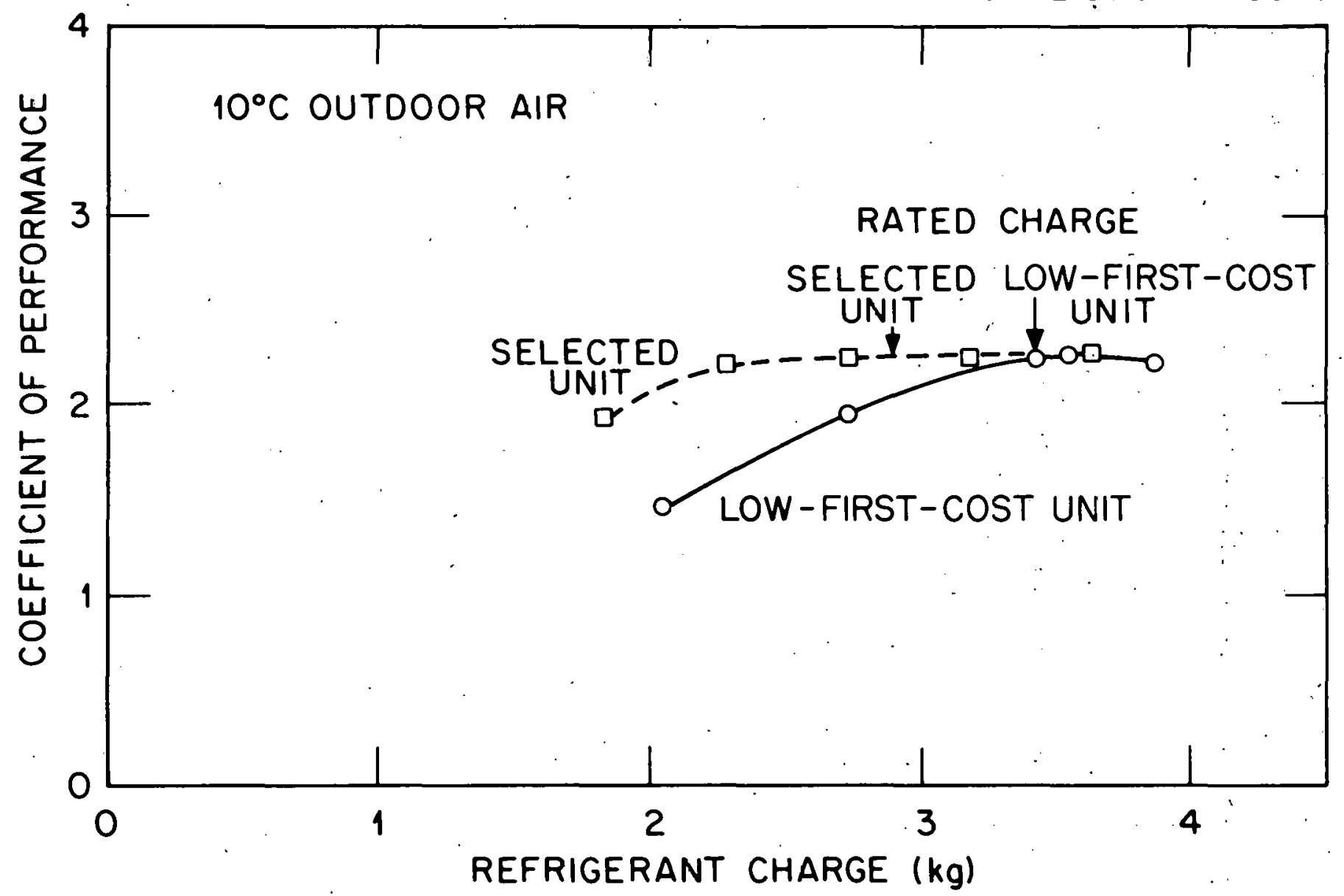

Fig. 8.5. Coefficient of performance as a function of refrigerant charge. The cop of the lowfirst-cost unit, which lacks a suction line accumulator, is shown for comparison. 


\section{ACKNOWLEDGMENTS}

Thanks are due to $D$. E. Holt, who was responsible for the assembly and operation of the laboratory apparatus; to J. E. Summers and N. E. Morgan, for their help in solving instrument application problems; and to $\mathrm{J}$ : T. Farmer and $\mathrm{T}$. Duncan who helped maintain the refrigerant 1oop in working condition.

The authors are grateful for the assistance and advice of R. D. Ellison and F. A. Creswick in reviewing and editing the report. The help of W. L. Jackson in preparing the computer program for the evaluation of the testing data and preparation of the computer plot routines is gratefully acknowledged. 


\section{REFERENCES}

1. A. A. Domingorena, Performance Evaluation of a Low-First-Cost, Three-Ton, Air-to-Air Heat Pump in the Heating Mode, ORNL/CON-18 (October 1978).

2. R. D. Ellison and F. A. Creswick, A Computer Simuzation of SteadyState Performance of Air-to-Air Heat Pumps, ORNL/CON-16 (March 1978).

3. Thermocouple Conversion Tables, NBS Circular 561. 


\section{THIS PAGE}

\section{WAS INTENTIONALLY \\ LEFT BLANK}


APPENDICES 
THIS PAGE

WAS INTENTIONALLY

LEFT BLANK 
Appendix A. Experimental Data

Table A.l shows the data collected and the results of some of the calculations needed for evaluating the performance of the heat pump system operating under the steady-state (non-frosting) conditions in the heating mode. Table A.2 gives the same information for the frosting runs. Data from the refrigerant charge varation tests are presented in Table A.3. Air-side measurements were not required for these tests. 
THIS PAGE

\section{WAS INTENTIONALLY LEFT BLANK}


Table A.1. Test data from steady-state runs.

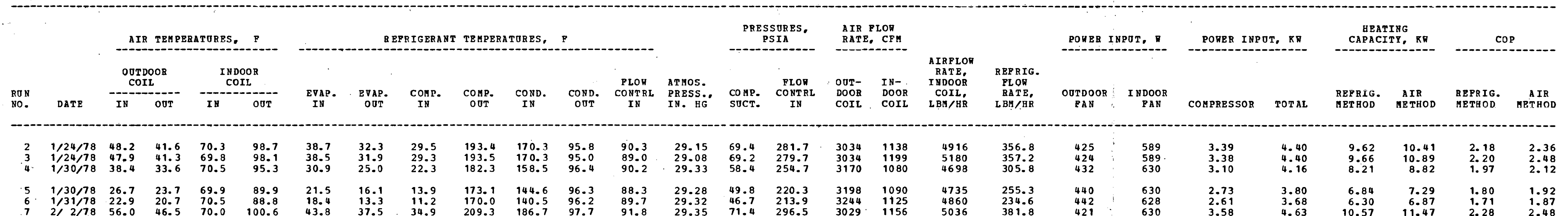


Táble A.2. Test data for frosting/defrosting tests.

\begin{tabular}{|c|c|c|c|c|c|c|c|c|c|c|c|c|c|c|c|c|c|c|}
\hline \multirow[b]{2}{*}{$\begin{array}{c}\text { REPRIG. } \\
\text { CHARGE } \\
\text { (IBBM) }\end{array}$} & \multicolumn{2}{|c|}{ AIR TEMPERATURES } & \multicolumn{7}{|c|}{ REPRIGRRANT TEM PERATURES, } & \multicolumn{2}{|c|}{$\begin{array}{c}\text { PRESSORES } \\
\text { PSIA }\end{array}$} & \multirow[b]{2}{*}{$\begin{array}{l}\text { REPRIG. } \\
\text { PLOR } \\
\text { RATE, } \\
\text { LBMMHR }\end{array}$} & \multicolumn{2}{|c|}{ POHER INPOT, } & \multicolumn{2}{|c|}{ PORER INPUT, RR } & \multirow{2}{*}{ 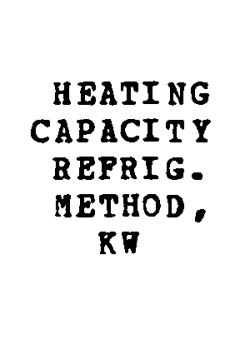 } & \multirow{2}{*}{$\begin{array}{c}\text { COP } \\
\text { REPRIG. } \\
\text { METHOD }\end{array}$} \\
\hline & $\begin{array}{c}\text { OOTDOOR } \\
\text { COII } \\
\text { IN, } \\
\text { P }\end{array}$ & $\begin{array}{c}\text { INDOOR } \\
\text { COIL } \\
\text { IN, } \\
\text { F }\end{array}$ & $\underset{\text { IN }}{\text { EVAP. }}$ & $\begin{array}{c}\text { EVAP. } \\
\text { OUT }\end{array}$ & $\underset{\mathrm{TN}}{\cos P .}$ & $\begin{array}{l}\text { comp. } \\
\text { OOT }\end{array}$ & $\underset{\text { IN }}{\text { COND. }}$ & $\begin{array}{l}\text { coND. } \\
\text { OOT }\end{array}$ & $\begin{array}{l}\text { PLOR } \\
\text { CONT RL } \\
\text { IN }\end{array}$ & $\begin{array}{l}\text { Conp. } \\
\text { SOCT. }\end{array}$ & $\begin{array}{c}\text { PLOR } \\
\text { CONTBL } \\
\text { IN }\end{array}$ & & $\begin{array}{l}\text { OUTDOOR } \\
\text { PAN }\end{array}$ & $\underset{\text { PAN }}{\text { INDOOR }}$ & COMPRESSOR & TOTAL & & \\
\hline $\begin{array}{l}8.00 \\
7.50 \\
7.00 \\
6.69\end{array}$ & $\begin{array}{l}50.0 \\
50.3 \\
49.4 \\
50.9\end{array}$ & $\begin{array}{l}69.9 \\
69.7 \\
69.8 \\
70.0\end{array}$ & $\begin{array}{l}39.3 \\
39.2 \\
38.9 \\
39.7\end{array}$ & $\begin{array}{l}33.3 \\
33.3 \\
32.9 \\
32.6\end{array}$ & $\begin{array}{l}31.8 \\
31.8 \\
31.4 \\
32.2\end{array}$ & $\begin{array}{l}185.3 \\
189.8 \\
188.2 \\
189.4\end{array}$ & $\begin{array}{l}169.5 \\
172.6 \\
171.8 \\
172.6\end{array}$ & $\begin{array}{l}93.7 \\
93.7 \\
93.3 \\
911.0\end{array}$ & $\begin{array}{l}89.8 \\
89.6 \\
89.4 \\
89.8\end{array}$ & $\begin{array}{l}72.0 \\
771.9 \\
72.0 \\
72.2\end{array}$ & $\begin{array}{l}291.0 \\
291.0 \\
289.0 \\
290.0\end{array}$ & $\begin{array}{l}368.0 \\
367.2 \\
365.0 \\
369.0\end{array}$ & $\begin{array}{l}420 \\
416 \\
418 \\
416\end{array}$ & $\begin{array}{l}590 \\
590 \\
590 \\
590\end{array}$ & $\begin{array}{l}3.43 \\
3.43 \\
3.42 \\
3.45\end{array}$ & $\begin{array}{l}4.44 \\
4.44 \\
4.43 \\
4.45\end{array}$ & $\begin{array}{r}9.92 \\
9.98 \\
9.92 \\
10.02\end{array}$ & $\begin{array}{l}2.23 \\
2.25 \\
2.24 \\
2.25\end{array}$ \\
\hline $\begin{array}{l}6.31 \\
6.00 \\
5.00 \\
4.00\end{array}$ & $\begin{array}{l}50.3 \\
49.9 \\
49.9 \\
50.0\end{array}$ & $\begin{array}{l}70.2 \\
70.8 \\
69.7 \\
70.4\end{array}$ & $\begin{array}{l}39.4 \\
33.8 \\
37.6 \\
27.8\end{array}$ & $\begin{array}{l}33.2 \\
32.8 \\
46.2 \\
52.6\end{array}$ & $\begin{array}{l}31.8 \\
31.2 \\
51: 1 \\
60.8\end{array}$ & $\begin{array}{l}189.7 \\
195.5 \\
224.6 \\
239.7\end{array}$ & $\begin{array}{l}172.6 \\
177.5 \\
203.8 \\
206.0\end{array}$ & $\begin{array}{l}93.9 \\
94.6 \\
94.6 \\
95.8\end{array}$ & $\begin{array}{l}90.0 \\
90.4 \\
90.3 \\
90.8\end{array}$ & $\begin{array}{l}71.7 \\
71.6 \\
69.0 \\
65.5\end{array}$ & $\begin{array}{l}290.0 \\
288.0 \\
268.0 \\
225.0\end{array}$ & $\begin{array}{l}365.0 \\
357.0 \\
321.0 \\
234.0\end{array}$ & $\begin{array}{l}418 \\
419 \\
420 \\
417\end{array}$ & $\begin{array}{l}590 \\
590 \\
590 \\
590\end{array}$ & $\begin{array}{l}3.43 \\
3.41 \\
3.25 \\
3.73 \\
3.73\end{array}$ & $\begin{array}{l}4.44 \\
4.42 \\
4.26 \\
4.73\end{array}$ & $\begin{array}{l}9.92 \\
9.81 \\
9.46 \\
7.14\end{array}$ & $\begin{array}{l}2.24 \\
2.22 \\
2.22 \\
1.51\end{array}$ \\
\hline
\end{tabular}


Table A.3. Test data for charge variation tests.

\begin{tabular}{|c|c|c|c|c|c|c|c|c|c|c|c|c|c|c|c|c|c|c|c|c|c|c|c|c|c|c|c|c|}
\hline \multirow{3}{*}{ 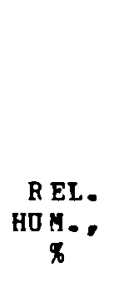 } & \multirow[b]{3}{*}{ DATE } & \multirow{3}{*}{$\begin{array}{c}\text { PROSTING } \\
\text { THES } \\
\text { MIN }\end{array}$} & \multicolumn{4}{|c|}{ AIR TERPPRATORES, $P$} & \multicolumn{7}{|c|}{ REPRIGERANT TEMPRRATORES, $P$} & \multirow{3}{*}{$\begin{array}{l}\text { ATMOS. } \\
\text { PRESS: } \\
\text { rN. }\end{array}$} & \multicolumn{2}{|c|}{$\begin{array}{c}\text { PRESSORES, } \\
\text { PSIA } \\
\end{array}$} & \multicolumn{2}{|c|}{ 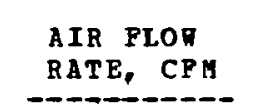 } & \multirow{3}{*}{ 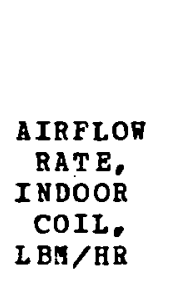 } & \multirow{3}{*}{ 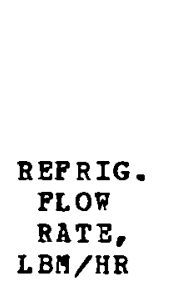 } & \multicolumn{2}{|c|}{ POHBR I PPOT, } & \multicolumn{2}{|c|}{ POHER INPOT, KW } & \multicolumn{2}{|c|}{$\begin{array}{c}\text { HEATING } \\
\text { CARCITY KH }\end{array}$} & \multicolumn{2}{|c|}{ COP } \\
\hline & & & \begin{tabular}{c} 
ov \\
col \\
\hdashline \\
-
\end{tabular} & L & & $\begin{array}{ll}\mathrm{OOH} \\
\mathrm{II}\end{array}$ & & & & & & & $\begin{array}{c}\text { PLOR } \\
\text { CONTRL }\end{array}$ & & & 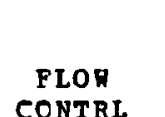 & 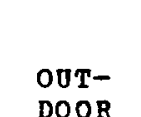 & $\begin{array}{l}\text { Ir- } \\
\text { DoOB }\end{array}$ & & & & & & & & & & \\
\hline & & & IM & OOT & IN & OOT & 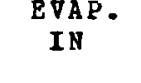 & 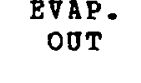 & IN & comp. & 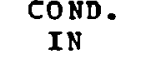 & $\begin{array}{c}\text { cond. } \\
\text { ovr }\end{array}$ & $\underset{\mathrm{IN}}{\operatorname{conpre}}$ & & $\begin{array}{l}\text { Solpe: } \\
\text { suct. }\end{array}$ & 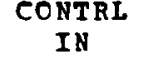 & $\begin{array}{c}\text { Door } \\
\text { COIL }\end{array}$ & $\begin{array}{c}\text { DooB } \\
\text { cort }\end{array}$ & & & 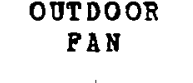 & $\begin{array}{l}\text { INDOR } \\
\text { PAN }\end{array}$ & COMPRESSOR & TOTAL & $\begin{array}{l}\text { RePrG. } \\
\text { METHOD }\end{array}$ & $\begin{array}{l}\text { AIR } \\
\text { METHOD }\end{array}$ & 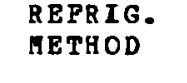 & $\begin{array}{l}\text { AIR } \\
\mathrm{BPTHOD}\end{array}$ \\
\hline $\begin{array}{l}100 \\
100 \\
100 \\
100 \\
100 \\
100\end{array}$ & 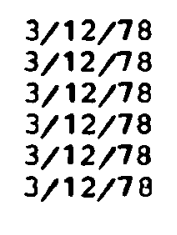 & $\begin{array}{l}18 \\
20 \\
33 \\
36 \\
48 \\
50\end{array}$ & $\begin{array}{l}33.5 \\
33.1 \\
35.1 \\
33.4 \\
43.7 \\
39.7 \\
39.5\end{array}$ & $\begin{array}{l}31.5 \\
30.9 \\
30.7 \\
30.7 \\
20.3 \\
25.1 \\
25.5\end{array}$ & $\begin{array}{l}70.8 \\
70.7 \\
70.8 \\
70.4 \\
70.4 \\
70.4\end{array}$ & $\begin{array}{l}94.9 \\
94.4 \\
94.4 \\
93.8 \\
90.4 \\
90.4\end{array}$ & $\begin{array}{l}28.8 \\
28.2 \\
28.0 \\
27.7 \\
22.2 \\
22.2 .2\end{array}$ & $\begin{array}{l}22.7 \\
22.5 \\
212.8 \\
22.0 \\
15.3 \\
1.3 .1\end{array}$ & $\begin{array}{l}21.8 \\
21: 1 \\
20.4 \\
20.4 \\
14.7 \\
14.7\end{array}$ & $\begin{array}{l}181.9 \\
1796 \\
179.7 \\
178.7 \\
174.5 \\
173.8\end{array}$ & $\begin{array}{l}158.5 \\
156.5 \\
156.9 \\
154.8 \\
147.8 \\
147.1 \\
146.8\end{array}$ & $\begin{array}{l}96.8 \\
966.6 \\
996.8 \\
996.4 \\
996.5 \\
96.5\end{array}$ & $\begin{array}{l}90.7 \\
90.4 \\
90.4 \\
99.8 \\
90.0 \\
89.0\end{array}$ & $\begin{aligned} 29.29 \\
29.29 \\
29.29 \\
29.25 \\
29.29 \\
29.29\end{aligned}$ & $\begin{array}{l}50.7 \\
59.7 \\
58.5 \\
58.5 \\
510.2 \\
51.06\end{array}$ & $\begin{aligned} 2544.7 \\
252.0 \\
247.2 \\
246.2 \\
246.2 \\
223.2 \\
223.7\end{aligned}$ & $\begin{array}{r}3359 \\
3174 \\
1946 \\
2114 \\
470 \\
566\end{array}$ & $\begin{array}{l}1090 \\
1090 \\
1090 \\
10900 \\
10900 \\
1090\end{array}$ & $\begin{array}{l}4709 \\
4709 \\
4709 \\
4709 \\
4709 \\
4709\end{array}$ & $\begin{array}{l}298.6 \\
2950.6 \\
290.5 \\
298.5 \\
296.6 \\
244.8 \\
244.8\end{array}$ & $\begin{array}{l}420 \\
499 \\
396 \\
398 \\
490 \\
495\end{array}$ & $\begin{array}{l}610 \\
610 \\
610 \\
610 \\
610 \\
610 \\
610\end{array}$ & $\begin{array}{l}3.04 \\
3.01 \\
2.097 \\
22.966 \\
22.69 \\
2.69\end{array}$ & $\begin{array}{l}4.07 \\
43.04 \\
33.97 \\
33.97 \\
3.79 \\
3.79\end{array}$ & $\begin{array}{l}8.00 \\
77.90 \\
7.79 \\
7.72 \\
6.64 \\
6.59\end{array}$ & $\begin{array}{l}8.58 \\
8.44 \\
88.34 \\
88.34 \\
77.22 \\
7.22\end{array}$ & $\begin{array}{l}1: 97 \\
1: 95 \\
1: 96 \\
1: 94 \\
1: 75 \\
1: .74\end{array}$ & $\begin{array}{rl}2 & 211 \\
2 & 09 \\
2 & 090 \\
2: 10 \\
1: 910 \\
1: 90\end{array}$ \\
\hline $\begin{array}{l}92-97 \\
992-97 \\
992-97 \\
992-97 \\
92-97 \\
92-97\end{array}$ & 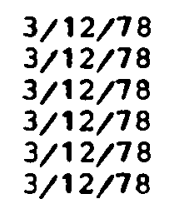 & $\begin{array}{l}20 \\
25 \\
38 \\
73 \\
80 \\
88\end{array}$ & $\begin{array}{l}33.2 \\
33.3 \\
33.5 \\
38.5 \\
36.0 \\
42.7\end{array}$ & $\begin{array}{l}30.5 \\
30.9 \\
30.9 \\
30.7 \\
20.8 \\
31.2 .1\end{array}$ & $\begin{array}{l}70.5 \\
69.6 \\
770.8 \\
70.80 \\
70.6 \\
70.3\end{array}$ & $\begin{array}{l}95.2 \\
94.5 \\
95.5 \\
93.0 \\
92.4 \\
90.4\end{array}$ & $\begin{array}{l}27.7 \\
27.7 \\
27.7 \\
27.5 \\
25.3 \\
24.0 \\
21.3\end{array}$ & $\begin{array}{l}22.0 \\
22.1 \\
22.8 \\
20.8 \\
18.5 \\
16.5 \\
16.4\end{array}$ & $\begin{array}{l}20.8 \\
20.7 \\
20.7 \\
18.0 \\
16.7 \\
14.0\end{array}$ & $\begin{array}{l}182.3 \\
1800.7 \\
1800.4 \\
177.0 \\
174.2 \\
172.2\end{array}$ & $\begin{array}{l}160.0 \\
158.5 \\
1580.4 \\
154.6 \\
15101 \\
147.3\end{array}$ & $\begin{array}{l}92.9 \\
991.8 \\
992.7 \\
922.6 \\
92.5 \\
93.5\end{array}$ & $\begin{array}{l}86.9 \\
85.9 \\
86.8 \\
86.8 \\
86.5 \\
87.5 \\
87.2\end{array}$ & $\begin{array}{l}29.29 \\
29.29 \\
29.33 \\
29.33 \\
29.29 \\
29.33\end{array}$ & $\begin{array}{l}58.7 \\
58.7 \\
58.0 \\
54.0 \\
52.5 \\
49.7\end{array}$ & $\begin{aligned} 244.7 \\
242.7 \\
242.7 \\
2422.0 \\
222.0 \\
217.0 \\
217.7\end{aligned}$ & $\begin{array}{c}3216 \\
3260 \\
3058 \\
1147 \\
901 \\
855\end{array}$ & $\begin{array}{l}1090 \\
1090 \\
10900 \\
1090 \\
1090 \\
1090\end{array}$ & $\begin{array}{l}4735 \\
47741 \\
47741 \\
4741 \\
4735 \\
47441\end{array}$ & 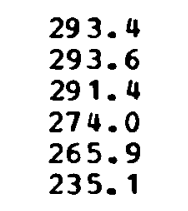 & $\begin{array}{l}497 \\
425 \\
427 \\
404 \\
426 \\
451\end{array}$ & $\begin{array}{l}610 \\
610 \\
610 \\
610 \\
610 \\
610\end{array}$ & $\begin{array}{l}2.99 \\
2.98 \\
2.98 \\
2.85 \\
2.78 \\
2.78 \\
2.63\end{array}$ & $\begin{array}{l}4.09 \\
4.02 \\
4.01 \\
3.806 \\
3.82 \\
3.69\end{array}$ & $\begin{array}{l}8.04 \\
8.05 \\
7.97 \\
7.50 \\
7.27 \\
6.44\end{array}$ & $\begin{array}{l}8.82 \\
88.90 \\
88.67 \\
8.20 \\
7.96 \\
7.34\end{array}$ & 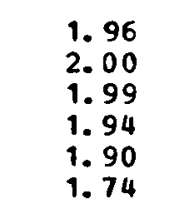 & $\begin{array}{l}2.16 \\
2.21 \\
2.16 \\
2.12 \\
2.08 \\
1.099\end{array}$ \\
\hline $\begin{array}{l}80-85 \\
80-85 \\
80-85\end{array}$ & $\begin{array}{l}3 / 12 / 78 \\
3 / 2,788 \\
3 / 12,788\end{array}$ & $\begin{array}{l}69 \\
64 \\
86\end{array}$ & $\begin{array}{l}29.8 \\
27.9 \\
27.7\end{array}$ & $\begin{array}{l}27.4 \\
27.4 \\
24.9\end{array}$ & $\begin{array}{l}711.2 \\
71: 5 \\
71: 1\end{array}$ & $\begin{array}{l}92.7 \\
92.0 \\
91.5\end{array}$ & $\begin{array}{l}24.8 \\
22.3 \\
21.6\end{array}$ & $\begin{array}{l}18.7 \\
16.4 \\
16.9\end{array}$ & $\begin{array}{l}19.1 \\
15.4 \\
15.0\end{array}$ & $\begin{array}{l}174.5 \\
174.7 \\
174.2\end{array}$ & $\begin{array}{l}151.7 \\
148.6 \\
147.6\end{array}$ & $\begin{array}{l}96.1 \\
997.0 \\
97.00\end{array}$ & $\begin{array}{l}90.0 \\
90.0 \\
90.1\end{array}$ & $\begin{array}{l}28.90 \\
28.90 \\
28.90\end{array}$ & $\begin{array}{l}56.5 \\
53.7 \\
53.5\end{array}$ & $\begin{array}{l}239.7 \\
234.7 \\
231 .-7\end{array}$ & $\begin{array}{l}33370 \\
3300 \\
3116\end{array}$ & $\begin{array}{l}1090 \\
1090 \\
1090\end{array}$ & $\begin{array}{l}4843 \\
4643 \\
4656\end{array}$ & $\begin{array}{l}272.2 \\
256.9 \\
250.8\end{array}$ & $\begin{array}{l}429 \\
425 \\
421\end{array}$ & $\begin{array}{l}610 \\
610 \\
610\end{array}$ & $\begin{array}{l}2.86 \\
2.78 \\
2.75\end{array}$ & $\begin{array}{l}3.90 \\
3.81 \\
3.78\end{array}$ & $\begin{array}{l}7.29 \\
6.86 \\
6.71\end{array}$ & $\begin{array}{l}7.64 \\
7.31 \\
7.30\end{array}$ & $\begin{array}{l}1.87 \\
\text { i: } 80 \\
\text { i. }\end{array}$ & $\begin{array}{l}1: 96 \\
1: 92 \\
1.93\end{array}$ \\
\hline
\end{tabular}


THIS PAGE

\section{WAS INTENTIONALLY LEFT BLANK}


Appendix B. Fan-Motor Efficiency Evaluation:

Table B.I shows the data used to determine the pressure head and power consumption of the indoor-unit fan as functions of the airflow rates.

Table B.1. Indoor fan test data

\begin{tabular}{|c|c|c|c|}
\hline & $\begin{array}{l}\text { Volume rate } \\
\text { of a ir } \\
\text { (cfm) }\end{array}$ & $\begin{array}{c}\text { Static-developed } \\
\text { head } \\
\left(\text { in. } \mathrm{H}_{2} \mathrm{O}\right)\end{array}$ & $\begin{array}{c}\text { Fan-motor } \\
\text { input power } \\
(\mathrm{kW})\end{array}$ \\
\hline \multirow{7}{*}{$\begin{array}{l}850 \\
\text { rpm }\end{array}$} & 203 & 1.32 & 0.239 \\
\hline & 560 & 1.15 & 0.320 \\
\hline & 787 & 1.02 & 0.388 \\
\hline & 1017 & 0.85 & 0.466 \\
\hline & 1116 & 0.745 & 0.527 \\
\hline & 1144 & 0.675 & 0.526 \\
\hline & 181 & 1.37 & 0.390 \\
\hline \multirow{5}{*}{$\begin{array}{l}950 \\
\mathrm{rpm}\end{array}$} & 576 & 1.22 & 0.461 \\
\hline & 836 & 1.12 & 0.515 \\
\hline & 1099 & 0.99 & 0.586 \\
\hline & 1252 & 0.915 & 0.650 \\
\hline & 1308 & 0.85 & 0.658 \\
\hline
\end{tabular}

The information contained in Table B. 1 was used to evaluate the overall efficiency of the fan-motor unit, as shown in Table B.2. 
Table B.2. Overall efficiency of the indoor fan-motor unit as a function of airflow rate

\begin{tabular}{|c|c|c|c|c|c|c|}
\hline \multicolumn{2}{|c|}{$\begin{array}{c}\text { Volumetric } \\
\text { flow rate } \\
{\left[\mathrm{m}^{3} / \mathrm{s}(\mathrm{cfm})\right]}\end{array}$} & \multicolumn{2}{|c|}{$\begin{array}{c}\text { Static- } \\
\text { developed } \\
\text { head } \\
{\left[\mathrm{kPa}\left(\text { in. } \mathrm{H}_{2} \mathrm{O}\right)\right]}\end{array}$} & $\begin{array}{l}\text { Air } \\
\text { power } \\
(\mathrm{kW})\end{array}$ & $\begin{array}{l}\text { Power } \\
\text { input } \\
\text { (kW) }\end{array}$ & $\begin{array}{l}\text { Overall } \\
\text { efficiency }\end{array}$ \\
\hline \multicolumn{7}{|c|}{ MED. SPEED $850 \mathrm{rpm}$} \\
\hline 0.890 & 203 & 0.329 & 1.32 & 0.0314 & 0.239 & 0.131 \\
\hline 0.264 & 560 & 0.286 & 1.15 & 0.0754 & 0.32 & 0.236 \\
\hline 0.371 & 787 & 0.254 & 1.02 & 0.094 & 0.388 & 0.242 \\
\hline 0.480 & 1017 & 0.212 & 0.85 & 0.1012 & 0.466 & 0.217 \\
\hline 0.527 & 1116 & 0.186 & 0.745 & 0.0973 & 0.527 & 0.184 \\
\hline 0.540 & 1144 & 0.168 & 0.675 & 0.0904 & 0.526 & 0.172 \\
\hline \multicolumn{7}{|c|}{ HIGH SPEED $950 \mathrm{rpm}$} \\
\hline 0.085 & 181 & 0.341 & 1.37 & 0.029 & 0.39 & 0.074 \\
\hline 0.272 & 576 & 0.304 & 1.22 & 0.0823 & 0.461 & 0.179 \\
\hline 0.395 & 836 & 0.279 & 1.12 & 0.1096 & 0.515 & 0.213 \\
\hline 0.519 & 1099 & 0.247 & 0.99 & 0.1274 & 0.586 & 0.217 \\
\hline $0.591^{\circ}$ & 1252 & 0.228 & 0.915 & 0.1342 & 0.65 & 0.206 \\
\hline 0.617 & 1308 & 0.212 & 0.85 & 0.1302 & 0.658 & 0.198 \\
\hline
\end{tabular}

The four experimental runs used to obtain the curves for the head vs capacity and input-power vs capacity for the outdoor fan are displayed in Table B.3. 
Table-B.3. Outdoor fan test data

\begin{tabular}{ccc}
$\begin{array}{c}\text { Volume rate } \\
\text { of air } \\
(\mathrm{cfm})\end{array}$ & $\begin{array}{c}\text { Static-developed } \\
\text { head } \\
\left(\text { in. } \mathrm{H}_{2} \mathrm{O}\right)\end{array}$ & $\begin{array}{c}\text { Fan-motor } \\
\text { input power } \\
(\mathrm{kW})\end{array}$ \\
\hline 151 & 0.40 & 0.491 \\
1419 & 0.305 & 0.435 \\
2037 & 0.245 & 0.413 \\
2548 & 0.18 & 0.400 \\
2837 & 0.125 & 0.396 \\
\hline
\end{tabular}

The overall fan efficiency as a function of the volumetric airflow rate is displayed in Table B.4.

Table B.4. Overall efficiency of the outdoor fan-motor unit as a function of airflow rate

\begin{tabular}{ccccccc}
$\begin{array}{c}\text { Volumetric } \\
\text { flow rate } \\
{\left[\mathrm{m}^{3} / \mathrm{s}(\mathrm{cfm})\right]}\end{array}$ & $\begin{array}{c}\text { Static- } \\
\text { developed } \\
\text { head } \\
{\left[\mathrm{kPa}\left(\mathrm{in} . \mathrm{H}_{2} \mathrm{O}\right)\right]}\end{array}$ & $\begin{array}{c}\text { Air } \\
\text { power } \\
(\mathrm{kW})\end{array}$ & $\begin{array}{c}\text { Power } \\
\text { input } \\
(\mathrm{kW})\end{array}$ & $\begin{array}{c}\text { Overal1 } \\
\text { efficiency }\end{array}$ \\
\hline 0.071 & 151 & 0.100 & 0.40 & 0.00707 & 0.491 & 0.014 \\
0.670 & 1419 & 0.076 & 0.305 & 0.0507 & 0.435 & 0.117 \\
0.961 & 2037 & 0.061 & 0.245 & 0.0584 & 0.413 & 0.14 \\
1.203 & 2548 & 0.045 & 0.18 & 0.0537 & 0.400 & 0.134 \\
1.339 & 2837 & 0.031 & 0.125 & 0.0415 & 0.396 & 0.105 \\
\hline
\end{tabular}


THIS PAGE

\section{WAS INTENTIONALLY \\ LEFT BLANK}




\section{Appendix C. Algorithms for Calculating Thermodynamic Properties of Refrigerant 22}

The equations listed below were derived from the 1964 E. I. duPont refrigerant 22 tables and apply over the operating range of the heat pump $\left(10^{\circ} \mathrm{F}-150^{\circ} \mathrm{F}\right)$. They were coded and included with the computer programs described in Appendix E. The accuracy of the approximations as noted are judged to be consistent with the measurement accuracies.

1. Saturation temperature $\left(T_{S a t}\right)$ in ${ }^{\circ} \mathrm{F}$. Maximum error \pm 0.3 .

$$
T_{\text {sat }}=D[16.79+D(1.48+0.467 D)]-103.6 \text {, }
$$

where

$$
\begin{aligned}
D & =\ln \left(P_{\text {sat }}\right) \\
P_{\text {sat }} & =\text { saturation pressure, psia. }
\end{aligned}
$$

2. Enthalpy of saturated vapor $\left(h_{g}\right)$ in Btu/lb. Maximum error \pm 0.1 .

$$
h_{g}=104.5+T_{s a t}\left[0.0937-T_{\text {sat }}\left(0.279+0.015 T_{\text {sat }}\right) \times 10^{-4}\right] .
$$

3. Enthalpy of saturated liquid $\left(h_{f}\right)$ in Btu/lb. Maximum error \pm 0.05 .

$$
h_{f}=10.355+T_{s a t}\left[0.2732+T_{s a t}\left(0.54+0.01059 T_{s a t}\right) \times 10^{-4}\right]
$$

4. Specific heat of 1 iquid at constant pressure $\left(c_{p}\right)$ in $B t u / 1 b \cdot F^{\circ}$.
Maximum error \pm 0.002 .

$$
\begin{aligned}
c_{p}= & 0.265+T_{\text {sat }}\left[0.5868 \times 10^{-3}-T_{\text {sat }}\left(0.4337-0.003353 T_{\text {sat }}\right) \times\right. \\
& \left.10^{-5}\right] .
\end{aligned}
$$

5. Density of the liquid $(p)$ in $1 b / f^{3}$. Maximum error \pm 0.15 .

$$
\rho=83.56-T_{\text {sat }}\left(0.09229+0.31864 T_{\text {sat }} \times 10^{-3}\right) .
$$


84

6. Entropy of saturated vapor $\left(s_{g}\right)$ in Btu/lb.F $F^{\circ}$. Maximum error $\pm 0.4 \times 10^{-3}$.

$$
\begin{aligned}
& \mathrm{s}=0.2372-\mathrm{P}_{\mathrm{sat}}\left[0.28387-\mathrm{P}_{\mathrm{sat}}\left(0.1069 \times 10^{-2}-0.161 \mathrm{P}_{\text {sat }} \times\right.\right. \\
& { }_{\left.\left.0.10^{-5}\right)\right] \times 10^{-3}}
\end{aligned}
$$

7. Partial derivative of enthalpy with respect to temperature; ide., $\therefore$ change in superheated vapor enthalpy per $F^{\circ}$ superheat, in $(B t u / i b) / F^{\circ}$. Maximum error \pm 0.006 .

$$
\partial h /\left.\partial T\right|_{p}=0.15+0.32 P_{\text {sat }} \times 10^{-3}
$$

8. Partial derivative of entropy with respect to temperature, ie.; change in superheated vapor entropy per $F^{\circ}$ superheat, in $\left(B t u / i b{ }^{\circ} F\right) / F^{\circ}$. Maximum, error $\pm 0.2 \times 10^{-4}$.

$$
\partial s /\left.\partial \mathrm{T}\right|_{\mathrm{p}}=\left(0.32+3.0 \mathrm{P}_{\text {sat }} \times 10^{-4}\right) \times 10^{-3} \text {. }
$$


Appendix D. Computer Program for the Data Acquisition System

The data acquisition system used in the experiments described in this report consisted principally of an analog-to-digital converter, a scanner, and a Digital Equipment Corp. PDP-8E minicomputer. The programs stored in the minicomputer were written in a modified version of the FOCAL language; they are presented here in flow-chart form so that they may be readily adapted to other computer systems. Complete copies of the program are available on request.

Note that at the introduction to each flow chart, the teletype (TTY) entries required to run that particular program are noted, e.g., to run.

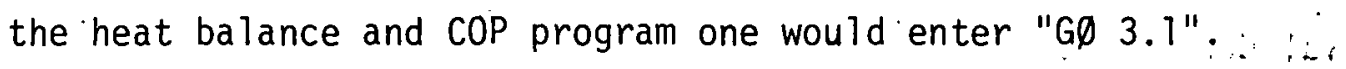

Supplementary data storage locations for use in FOCAL programs are identified as FSTR locations. Data System inputs are typically averaged and stored in arrays as $A(I)$. Those listed in the flow charts are identified as follows:
$\underline{A(1)}$
Description
100
Refrigerant temperature at compressor shell outlet
103
Refrigerant temperature at indoor coil distribution manifold
106 Indoor coill (condenser) discharge refrigerant temperature
107 Outdoor coil (evaporator) inlet refrigerant temperature
110 Outdoor coil refrigerant temperature (midpoint of coil)
Outdoor coil outlet refrigerant temperature
114
Refrigerant temperature at inlet to compressor shell
116
Outdoor coil inlet air temperature
117
Outdoor coil outlet air temperature
161
Indoor coil inlet air temperature
162
Indoor coil outlet air temperature
166
Compressor power
167
Outdoor fan power
168
Compressor suction pressure
169
Compressor discharge pressure 
The equations used to calculate COP and heating capacity (indoor coil power) are:

COP (bäsed on refrigerant side measurements):

$$
\operatorname{COP}(R)=Q(R) /(3.413 C D)
$$

COP (based on air side measurements):

$$
\operatorname{COP}(A)=Q(A) /(3.413 C D),
$$

where

$$
\begin{aligned}
& Q(R)=\text { indoor coil power, refrigerant side } \\
& =\dot{M}_{R}\left(h_{4}-h_{7}\right)+Q_{\text {indoor fan }} \\
& Q(A)=\text { indoor coil power, a'ir side } \\
& =\dot{M}_{A} C_{p(A)}\left(T_{\text {out }}-T_{\text {in }}\right)_{a i r} \\
& C D=\text { input power (watts) } \\
& =Q_{\text {indoor fan }}+Q_{\text {compressor }}+Q_{\text {outdoor fan }} \text {. } \\
& \dot{M}_{R}, \dot{M}_{A}=\text { refrigerant and indoor fan flows, } 1 \mathrm{~b} / \mathrm{hr} \\
& h_{4}, h_{7}=\text { refrigerant enthalpies at indoor coil inlet, outlet,. Btu/1.b } \\
& C_{p(A)}=\text { specific heat of air, }=0.24 \mathrm{Btu} / 1 \mathrm{~b}^{\circ} \mathrm{F}
\end{aligned}
$$


Preliminary Scan Program (record 4 points at 15 -second intervals to determine when process is at desired operating conditions)

To Start: $\quad G \emptyset$

To Continue: $G \emptyset 1.2$

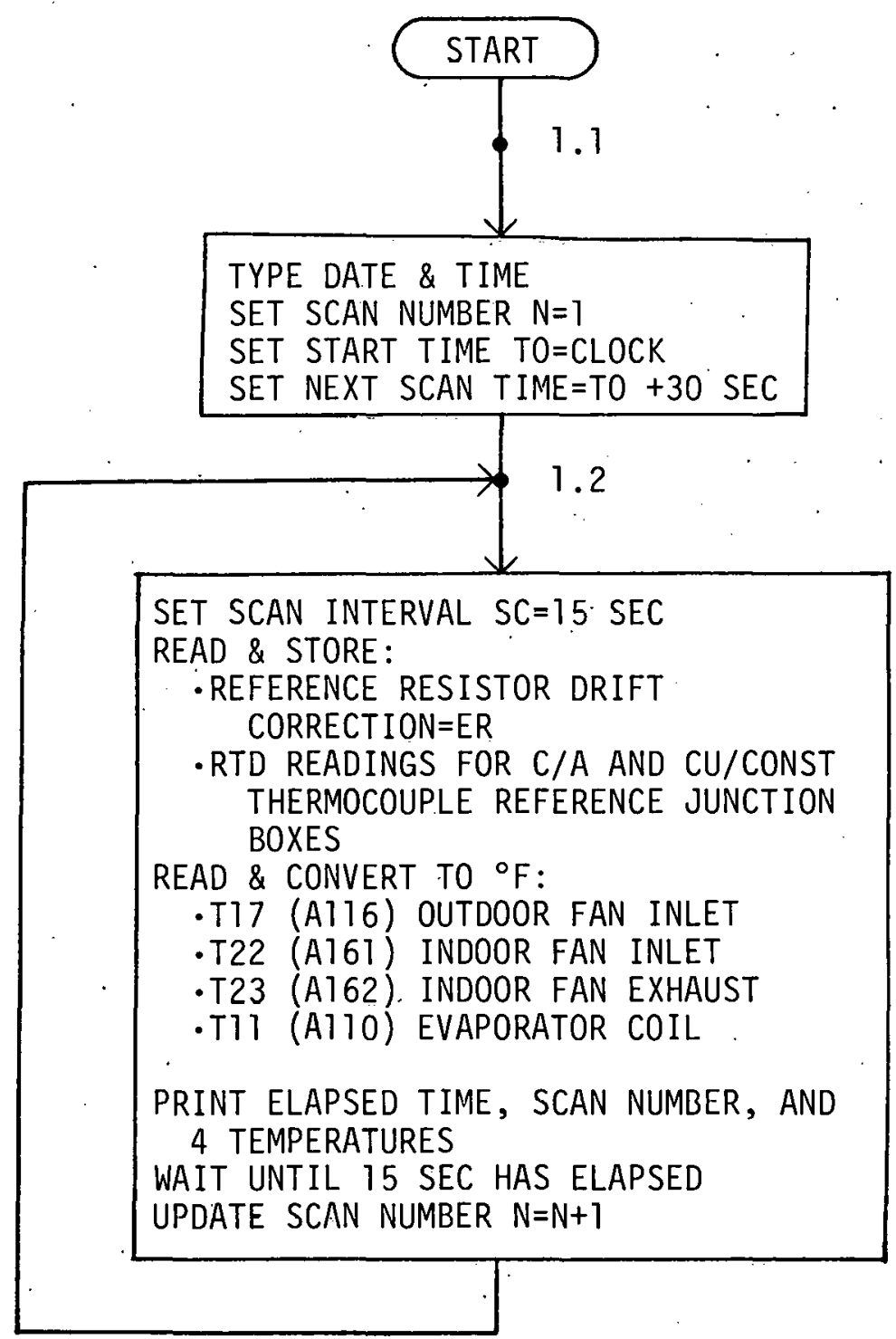


Auxiliary Program to Read Arbitrary DAS Inputs

To Start: $\quad D \emptyset 4$

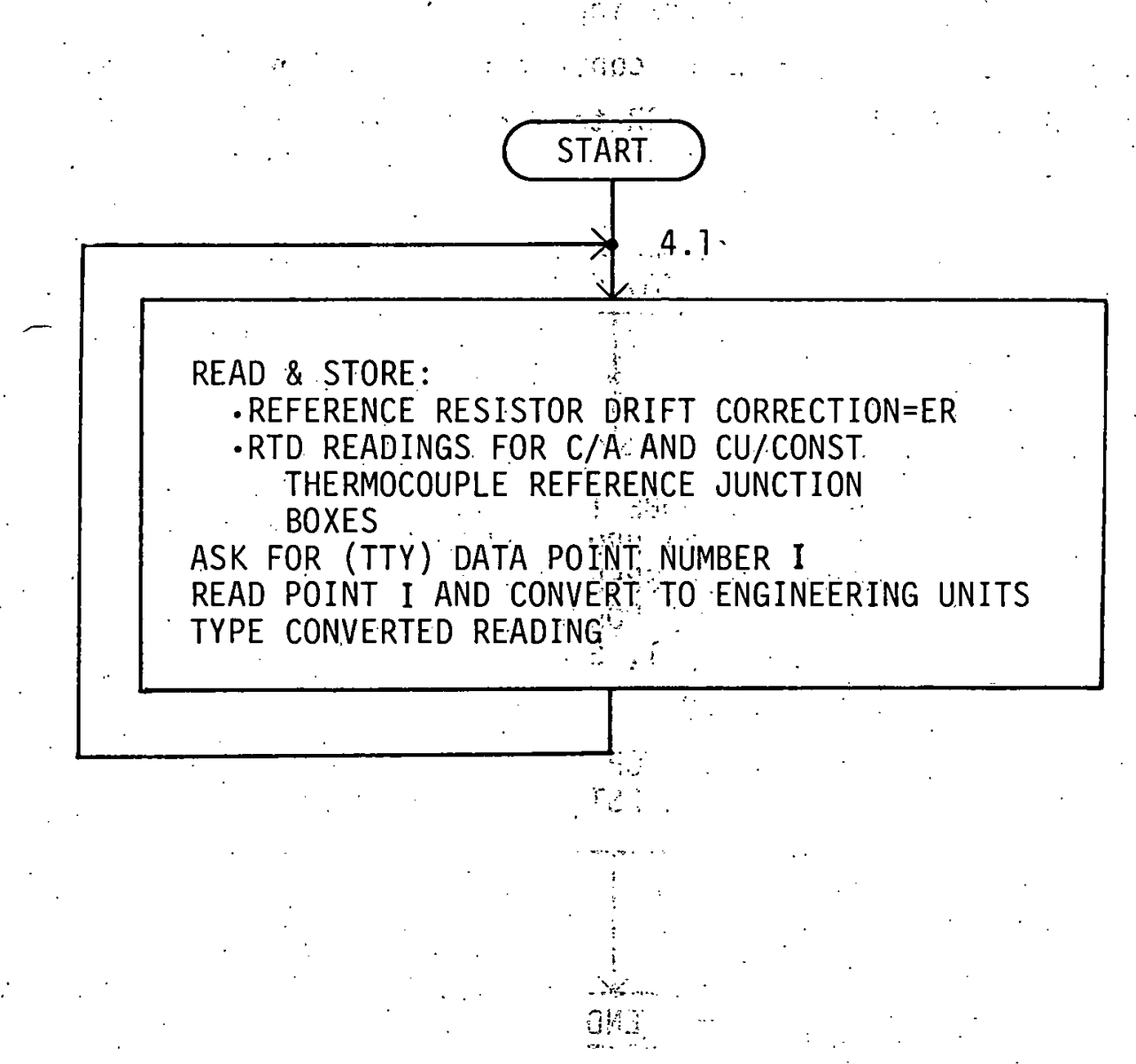


Auxiliary Program to Input Humidity Sensor Probes' Calibration Data and to Measure and Convert Probe Outputs

To Start: $\quad$ D 15 (calibration data input)

$D \emptyset 13$ [measure output, convert to equivalent dial reading (EDR)]

$D \emptyset$ 3.5-3.55 (convert EDR- to per cent relative humidity)

Calibration Data Input:
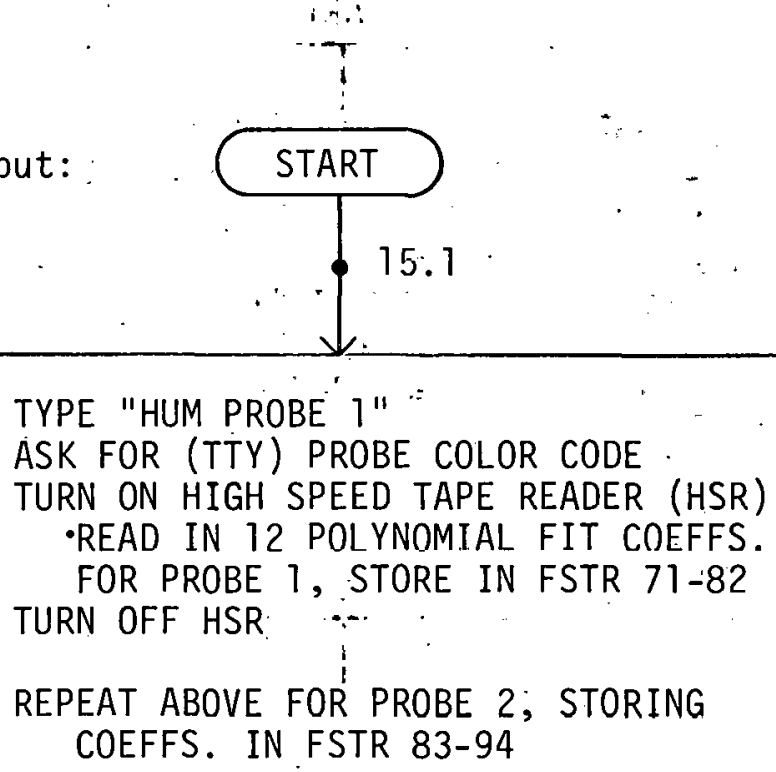

END 
Auxiliary Program to Input Humidity Sensor Probes' Calibration Data and to Measure and Convert Probe Outputs (continued)

Measure Output,

Convert to EDR:
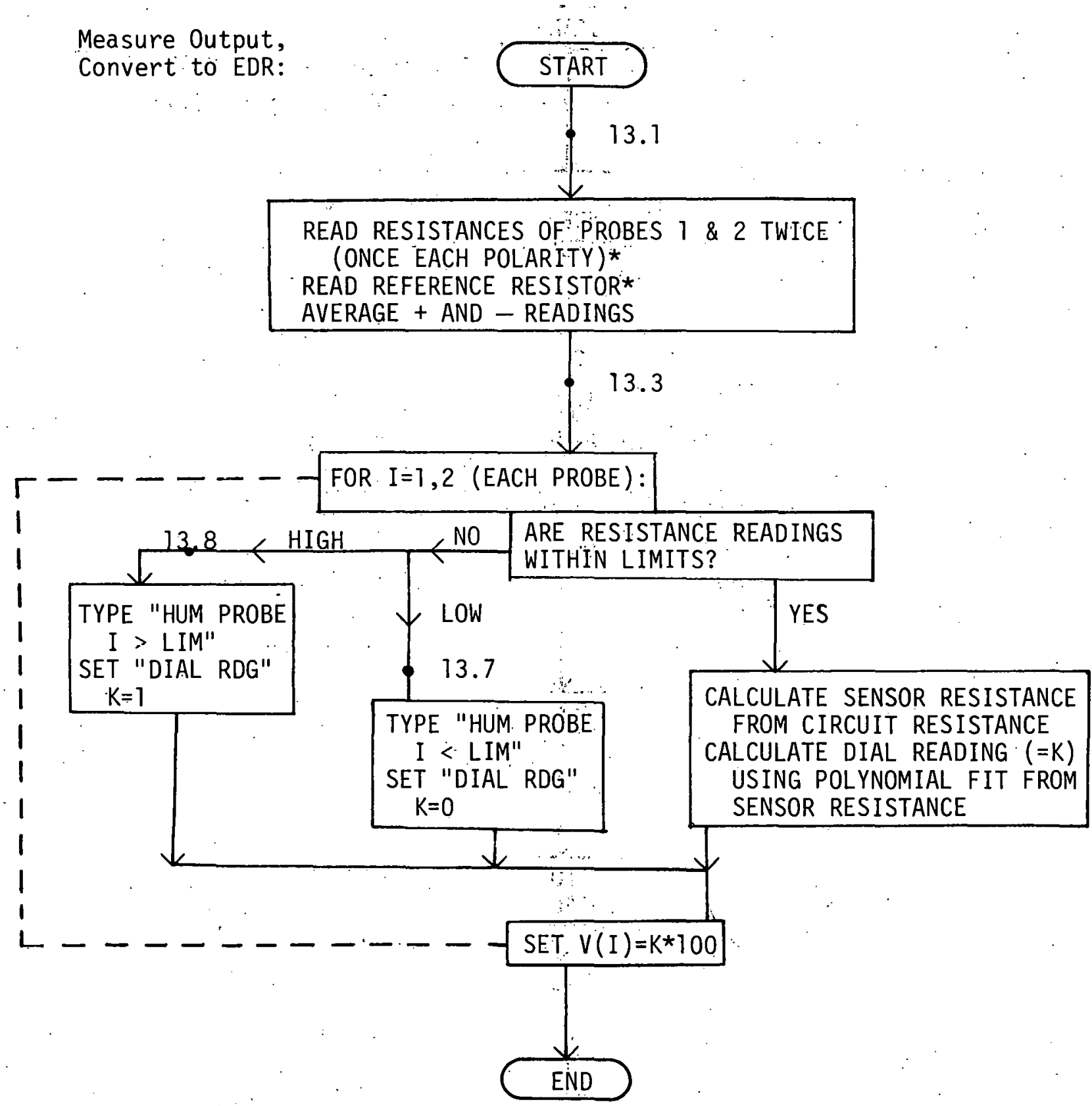

*Dunmore-type lithium-chloride hygrosensors are polarity sensitive and normally require a-c excitation. Prolonged $d-c$ causes migration and calibration shifts. 
Auxiliary Program to Input Humidity Sensor Probes' Calibration Data and to Measure and Convert Probe Outputs (continued)

Convert EDR to Per Cent Relative Humidity (RH):

START

3.5
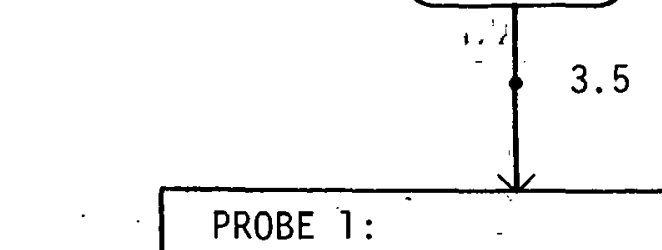

SET FSTR INDEX $\mathrm{H}=71$

SET TEMPERATURE AT PROBE 1 $T=A(116)$

SET $D=V(1)$ :

$1-f-$ DO 14

PROBE 2:

SET FSTR INDEX $\mathrm{H}=83$

SET TEMPERATURE AT PROBE 2 $T=A(117)$
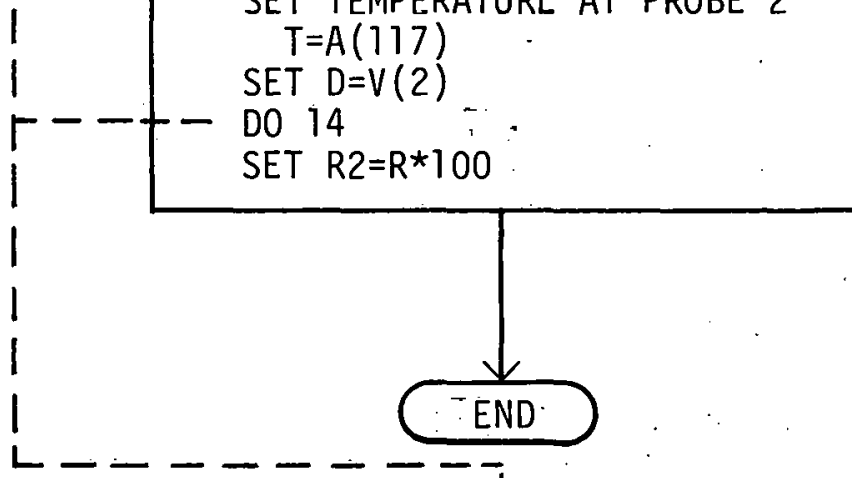

14.1

CALCULATE FRACTIONAL RH FOR EDR WITH POLYNOMIAL FOR $\mathrm{T}=40^{\circ} \mathrm{F},=\mathrm{R} 4$

CALCULATE FRACTIONAL RH FOR EDR WITH POLYNOMIAL

FOR $\mathrm{T}=20^{\circ} \mathrm{F},=\mathrm{RX}$

INTERPOLATE: $R=R X+(R 4-R X)(T-20) / 20$
CALCULATE FRACTIONAL RH

FOR EDR WITH POLYNOMIAL

FOR $T=80^{\circ} \mathrm{F},=\mathrm{RX}$

INTERPOLATE : $R=R 4+(R X-R 4)(T-40) / 40$ 
Auxiliary Program to Read Indoor Fan Flow (Manual Readings via Hot-Wire Anemometer)

To Start: $D \emptyset 16$
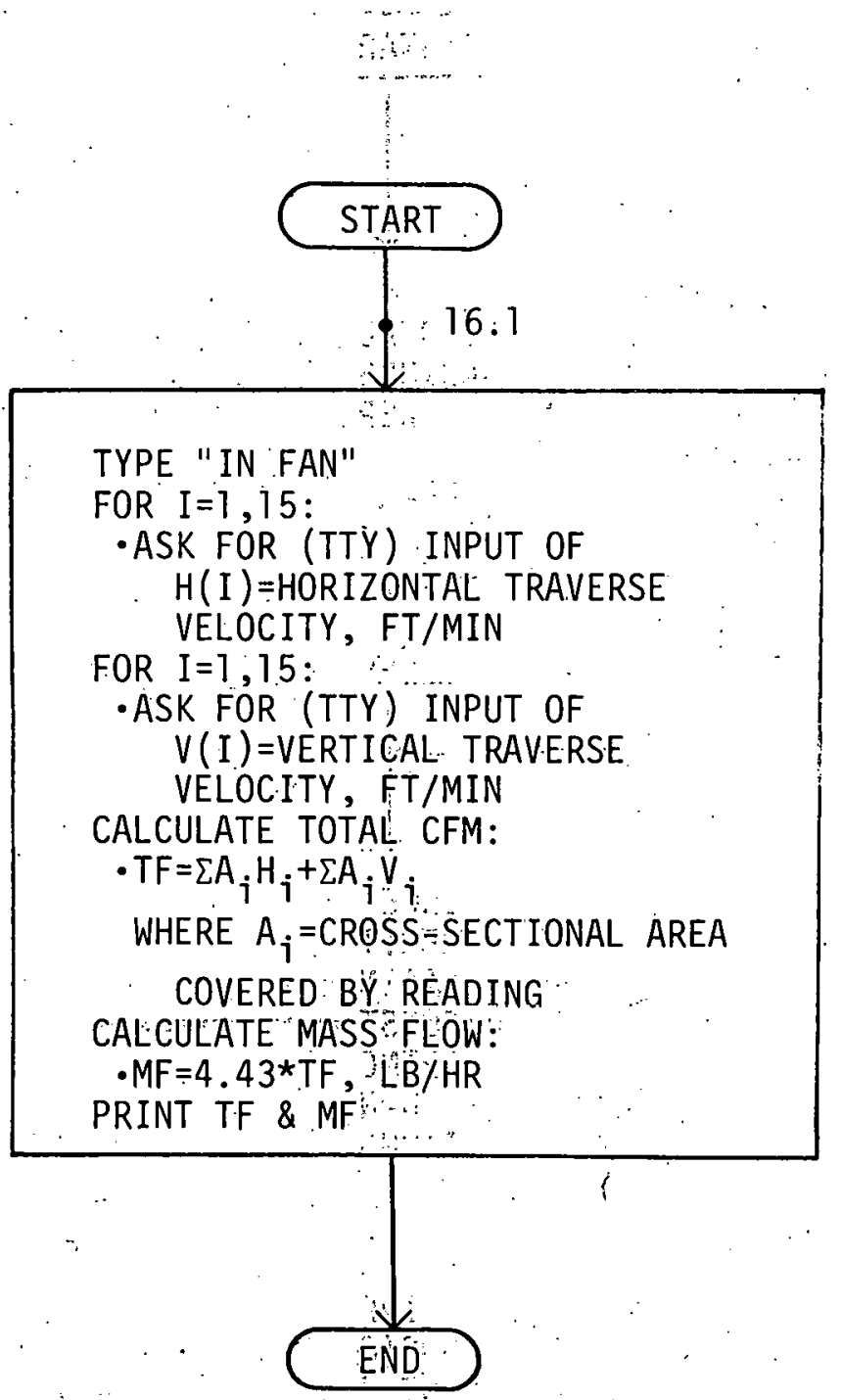
Heat Balance and COP Program - Heating Mode

To Start: GØ 3.1

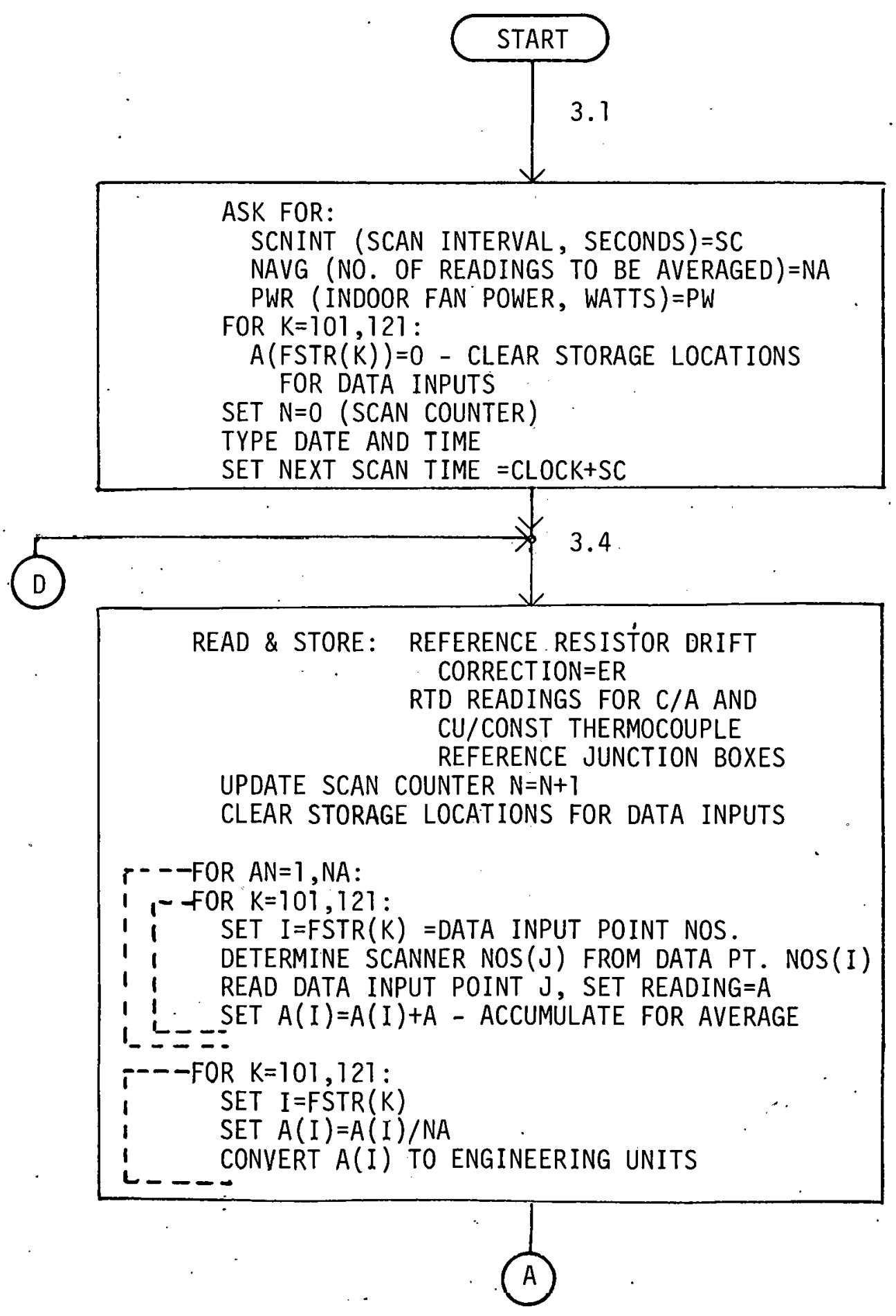


Heat Balance and COP Program - Heating Mode (continued)

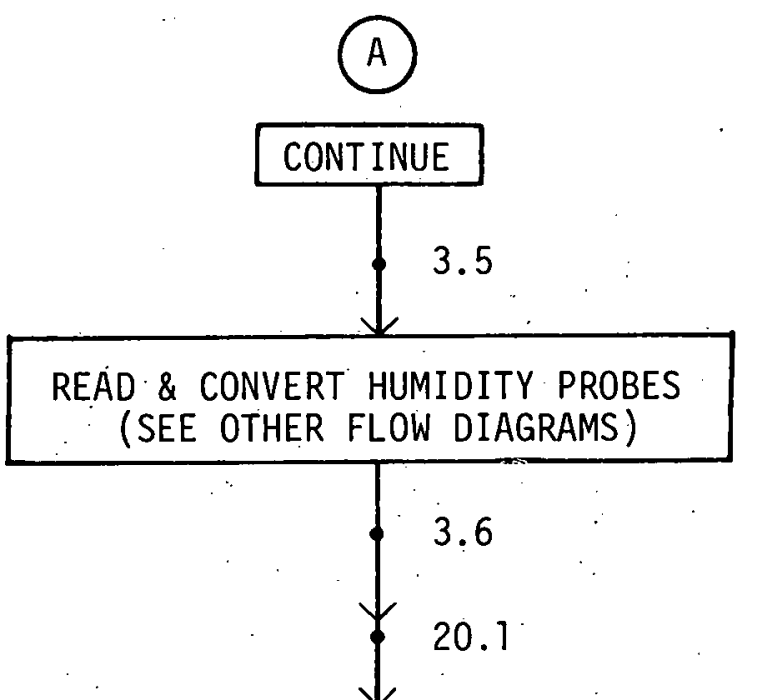

ASK: "ROTO" - ROTOMETER SCALE RDG. = RO

SET $T=A(107)$

CALCULATE ROTOMETER FLUID DENSITY FROM T, SET=DE

CALCULATE ROTOMETER MASS FLOW:

$M R=0.0153 * R 0 * D E /(0.451+0.0088 * D E)$

SET $P=A(169)$ - COMPRESSOR DISCHARGE PRESSURE, PSIA

CALCULATE T-SAT (=TS) AND hg ( $=H G$ ) FROM P

CALCULATE SUPERHEAT: : SW=A(1.03) - TS

CALCULATE $\partial h / \partial T(=H T)$.

CALCULATE COMPRESSOR DISCHARGE ENTHALPY:

$H 4=H G+H T \times S W$

ESTIMATE PRESSURE AT DISCHARGE OF INDOOR COIL:

$P=P-10$

CALCULATE T-SAT (=TS), $h_{f}(=H F)$, AND $c_{p}(=C P)$.

CALCULATE. INDOOR COIL DISCHARGE ENTHALPY:

$H 7=H F-C P(T S-A(106))$

ESTIMATE PRESSURE AT ACCURATOR INLET, PSIA:

$A=P-2$

CALCULATE T-SAT (=TS), $h_{f}(=H F)$, AND $C_{p}(=C P)$

CALCULATE ACCURATOR INLET ENTHALPY:

$H 8=H F-C P(T S-A(107))$

(NOTE: ACCURATOR $\triangle \mathrm{h}$ ASSUMED $=0$ ) 
Heat Balance and COP Program - Heating Mode (continued)

(B)

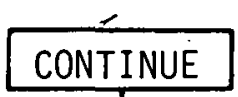

20.5

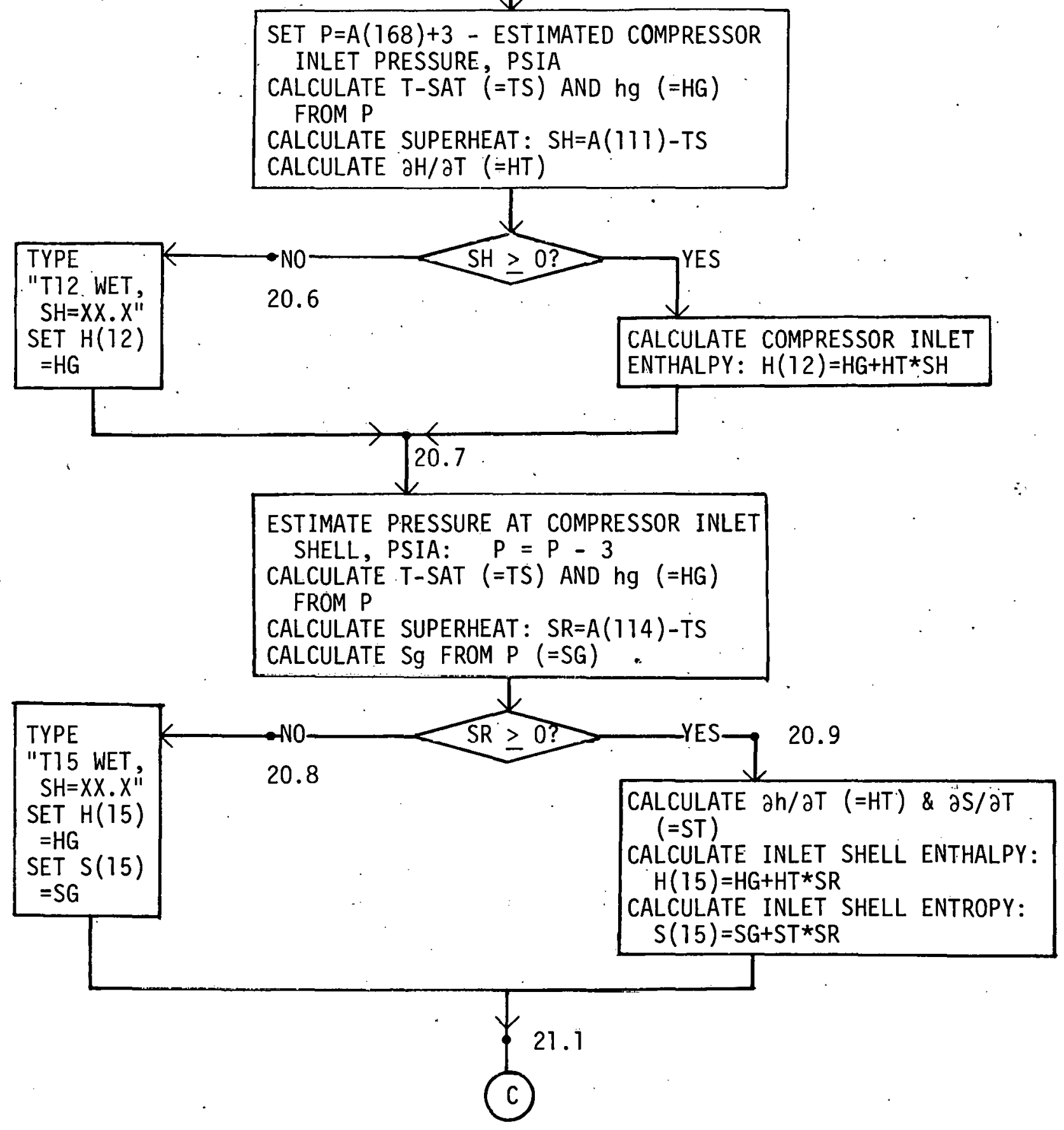


Heat Balance and COP. Program - Heating Mode (continued)
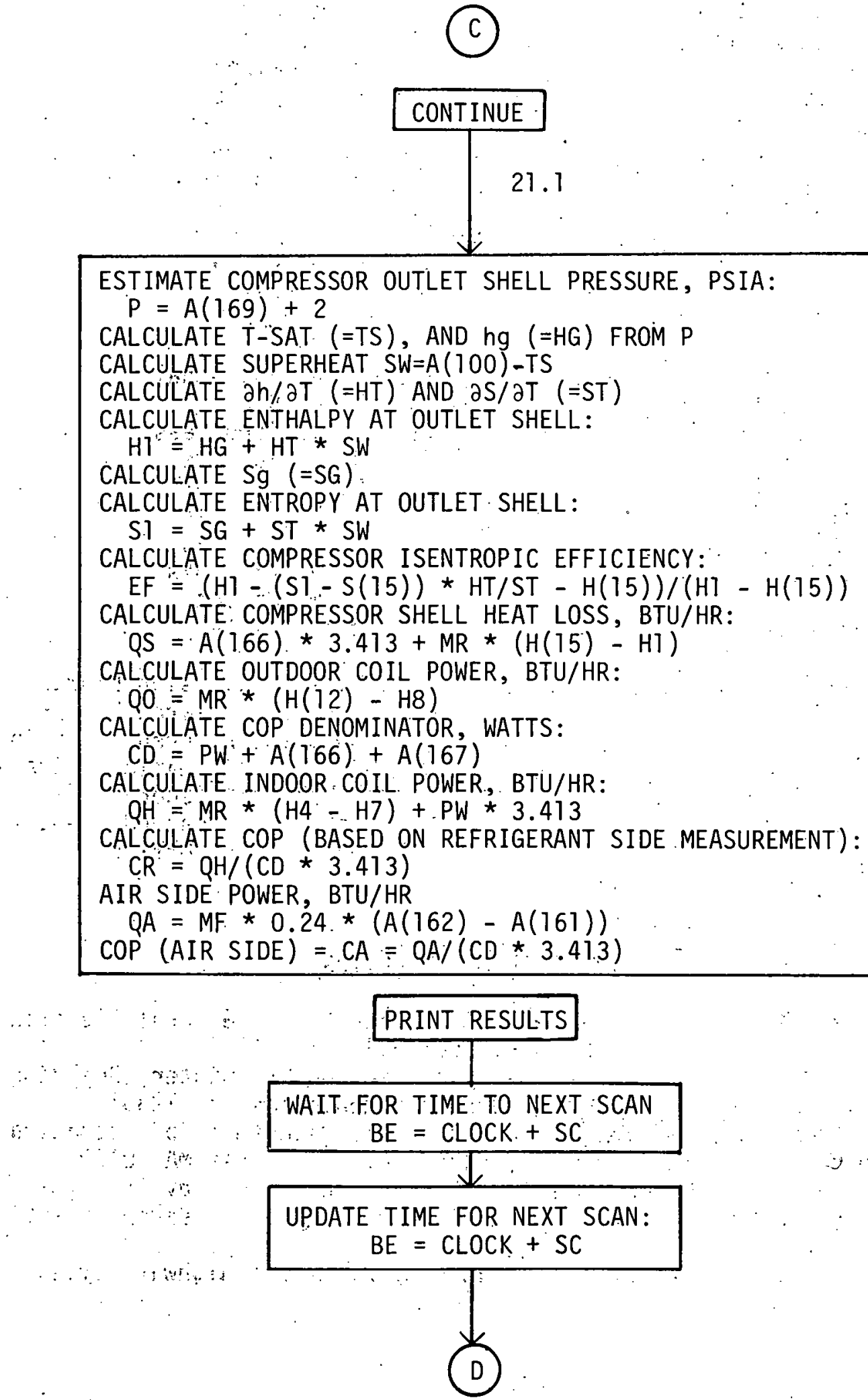
ORNL/CON-34

INTERNAL DISTRIBUTION

1. L. A. Abbatiello

2. S. I. Auerbach

3. S. J. Ball

4. R. W. Barnes

5. V. D. Baxter

6. D. J. Bjornstad

7. J. R. Buchanan

8. R. S. Carlsmith

9. W. S. Chern

10. C. V. Chester

11. K. R. Corum

12. F. A. Creswick

13. R. M. Davis

14. J. G. Dejlene

15. R. D. Ellison

16. P. D. Fairchild

17. J. T. Farmer

18. S. K. Fischer

19. W. Fulkerson

20. V. 0. Haynes

21. N. E. Hinkle

22. E. A. Hirst

23. D. E. Holt

24. C. C. Hopkins

25. M. M. Hutchinson

26. W. L. Jackson

27. P. L. Johnson

28. S. I. Kaplan

29. D. Kaserman

30. W. P. Levins

31. R. S. Livingston

32. H. M. Long
33-52. P. M. Love
53. C. R. Martin
54. J. W. Michel
55. W. A. Miller
56. R. E. Minturn
57-61. W. R. Mixon
62. N. E. Morgan
63. J. C. Moyers
64. E. A. Nephew
65. D. L. O'Neal
66. A. M. Perry
67. H. Postma
68. C. K. Rice
69. M. W. Rosenthal
70. T. H. Row
71: E. G. Struxness
72. J. E. Summers
73. D. B. Trauger
74. J. L. Trimble
75. D. J. Walukas
76. T. J. Wilbanks
77. J. V. Wilson
78. H. E. Zittel
79. A. Zucker
80. Biology Division Library
81-82. Central Research Library
83. Document Reference Section
84-85. Energy Information Library
86. Laboratory Records - RC
87-89. Laboratory Records Department
90. ORNL Patent Office

\section{EXTERNAL DISTRIBUTION}

91. Mr. Roy Abbott, Advance Technology Operations, General Electric Company, AP6, Appliance Park, Louisville KY 40225

92. Mr. Richard S. Alben, General Electric, GE R\&D Center, Building K-1, Room 5B37, Post Office Box 8, Schenectady NY 12301 .

93. Dr. Lawrence Ambs, Associate Professor, Department of Mechanical Engineering, University of Massachusetts, Amherst MA 01003

94. Dr. James C. Brisee, Director, North Carolina Energy Institute, Department of Commerce, Post Office Box 12235, Research Triangie Park NC 27709

95. Mr. Joe Canal, Gerieral Electric Company, Troup Highway, Tyler TX 75711 
96. Mr. John J. Cuttica; Chief, Technology and Consumer Products Branch, MS 2221C, Department of Energy, 20 Massachusetts Avenue NW, Washington DC 20545

97-101. Mr. Albert A. Domingorena, Carrier Corporation, Building TR-4, Carrier Parkway, Post Office Box 4808, Syracuse NY 13221

102. Mr. G. W. Gatecliff, Research Laboratory, Tecumseh Products Company, Ann Arbor MI 48105

103. Dr. L. R. Glicksman, Department of Mechanical Engineering, Massachusetts Institute of Technology, Cambridge MA 02139

104. Mr. S. D. Goldstein, Manager, Advanced Development Lab, Climate Control Division, The Singer Company, 1300 Federal Boulevard, Carteret NJ 07008

104. Mr. Gerald C. Groff, Research Division, Carrier Corporation, Syracuse NY 13201

104. Dr. C. C. Hiller, Sandia Laboratories, Livermore CA 94550

105. Mr. F. Honnold, Consumer Products Division, Carrier Corporation, Syracuse NY 13201

106. Mr. T. Jacoby, Tecumseh Products Company, Tecumseh MI 49286

107. Mr. H. Jaster, General Electric Corporation Research andDevelopment, General Electric Company, Schenectady NY 12301

108. Mr. F. Kalivoda, Copeland Corporation, Sydney $\mathrm{OH} 45365$

109. Mr. Rube Kelto, Tecumseh Products Company, Tecumseh MI 49286

110. Mr. R. W. King, Copeland Corporation, Sydney $\mathrm{OH} 45365$

111. Mr. Robert Mauro, Electric Power Research Institute, Palo Alto CA 94304

112. Mr. John Millhone, Director, Office of Buildings and Community Systems, Department of Energy, 20 Massachusetts Ávenue NW, Washington DC 20545

113. : Mr. Neno Nenov, Linde Division, Union Carbide Corporation, Tonawanda NY "14150

114. Mr. Michael Perlsweig, Department of Energy, Division of Conservation Research and Technology, 20 Massachusetts Avenue NW, Washington DC 20545

115. Dr. Kurt W. Riege1, Director, Consumer Products Division, MS 2221C, Department of Energy, 20 Massachusetts Avenue NW, Washington DC 20545

116. Mr. John D. Ryan, Program Manager, Technology and Consumer. Products Branch, MS 2221C, Department of Energy, 20 Massachusetts Avenue NW, Washington DC 20545

117. Mr. D. E: Sherpereel, Research and Engineering Center, Whirlpool Corporation, Benton Harbor MI 49022

118. Dr. M. H. Somerville, Engineering Experiment Station, University of. North Dakota, Grand Forks ND 58202

119. Mr. W. F. Stoecker, University of I1linois, Urbana IL 61801

120. Mr. M. Wilden, University of New Mexico, Albuquerque NM 87115

121. Institute of Energy Analysis, ORAU-Library

122. Research and Technical Support Division, DOE-ORO

123. Assistant Mañager, Energy Research and. Development, DOE-ORO

124-150. Technical Information Center, DOE, Post Office Box 62, Oak

151-701. External Energy Conservation Distribution Mailing List and Conservation Technology Office (Building 9102-1, Room 2) 